\title{
PREPRINT SUBMITTED
}

This manuscript is a preprint uploaded to EarthArXiv. This preprint has been submitted for publication to Sedimentology on the $10^{\text {th }}$ of March 2021. Authors enxourage downloading the latest manuscript version from EarthArXiv, and welcome comments, feedback and discussions anytime.

Please, feel free to get in contact: gino@ginodegelder.nl 


\section{Title:}

Micro-scale sedimentary signature of paleoearthquakes and paleotsunamis in the Corinth Rift (Greece).

Authors: Gino De Gelder ${ }^{1,2}$, Mai Linh Doan ${ }^{2}$, Christian Beck ${ }^{3}$, Julie Carlut ${ }^{1}$, Chloé Seibert ${ }^{1}$, Nathalie Feuillet ${ }^{1}$, Gareth D.O. Carter ${ }^{4}$, Sofia Pechlivanidou ${ }^{5}$, Robert L. Gawthorpe ${ }^{5}$

\section{Adresses:}

1) Institut de Physique du Globe de Paris, Paris, France.

2) Institut des Sciences de la Terre, Université Grenoble Alpes, France.

3) Institut des Sciences de la Terre, Université Savoie-Mont-Blanc, Le Bourget du Lac. France

4) British Geological Survey, The Lyell Centre, United Kingdom.

5) Department of Earth Science, University of Bergen, Norway.

Keywords : turbidites, homogenites, earthquakes, tsunamis, microtomography, Corinth Rift; IODP Expedition 381
Abstract:
A major challenge in subaqueous paleoseismology is to understand the relationship between an earthquake/tsunami and a sedimentary event recorded in drillcores. Expedition 381 of the International Ocean Discovery Program was dedicated to the development of the Corinth Rift, and its drilled cores provide a potentially important resource to better understand depositional mechanisms of sedimentary events within changing open marine to (semi-)isolated environments. To achieve this, we analyse U-channels and spatula samples from the topmost part (0-65 m below seafloor maximum depth) of cores M0078B and M0079A ( $\sim 0-25 \mathrm{ka})$, using high-resolution X-Ray microtomography in combination with grainsize, magnetic and XRF measurements. Structures and grain array are resolved down to $12 \mu \mathrm{m}$ in voxel size, characterizing the geometry of the basal surface of homogenite+turbidite sedimentary events, and the internal base-upwards evolution at high-resolution scale. The analysed events suggest these types of deposits are more complex than previously proposed, especially at the transition between the basal coarse turbidite sub-unit and the fine-grained homogenite upper sub-unit, as well as within the homogenite. Combined with the other observations and parameters, X-ray microtomography reinforces the interpretation of the Corinth $\mathrm{HmTu}$ deposits as having predominantly originated from paleoearthquake or paleotsunamis effects, despite subtle differences according to depositional environment. 


\section{1-Introduction}

Over previous decades, the discipline of "subaqueous paleoseismology" developed with the aim of contributing efficiently to earthquake hazards assessment (e.g. McCalpin, 2009). This approach needs to build on a tripartite relationship between 1) a sedimentary event bed 2) an earthquake with or without an associated tsunami wave, occasionally reported or recorded for historical times, and 3) an identified active fault, with possibly a localized rupture. Such paleoseismological methods are applied, event-by-event, to sedimentary records (either marine or lacustrine) that can span as much as tens of thousands of years (e.g. Marco and Agnon, 1995; Rodriguez-Pascua et al., 2002), with correlations established between several different sites (e.g. McHugh et al. 2006; Goldfinger et al., 2007; Gràcia et al., 2910; Polonia et al., 2013, 2017; Ratzov et al., 2015). Establishing relationships between element 3) and the two other components, requires a precise knowledge of a fault system activity, and of its neighbouring sedimentary fill (e.g. McHugh et al., 2014; Beck et al, 2012, 2015; Vanneste et al., 2018; Van Daele et al., 2019).

In this study we focus on the relationship between elements 1) and 2), specifically on the identification of confident criterions to attribute a particular bed and/or set of beds to an earthquake and/or to a tsunami wave.To achieve this, we benefit from the recent drilling and coring surveys achieved in the active Corinth Rift (Greece), within the framework provided by the 2017 International Ocean Discovery Program (IODP) Expedition 381 (McNeill et al., 2019a,b; Fig. 1). During this expedition, three primary holes were drilled at three sites (Fig. 1). Borehole M0078A achieved a depth of 610.43 metres below seafloor (mbsf) in water depths of approx. 860 metres below sea level (mbsl), borehole M0079A terminated at 704.9 mbsf in water depths of approx. $857 \mathrm{mbsl}$, and borehole M0080A penetrated to $534.1 \mathrm{mbsf}$ in water depths of approx. $349 \mathrm{mbsl}$. An additional short hole was drilled at Site M0078, located approx. $20 \mathrm{~m}$ south of borehole M0078A, in order to better capture the sediment-water interface and shallow subsurface stratigraphy. This borehole, M0078B, recovered sediments to a depth of 55.85 mbsf.

In the Corinth Rift, seismological and geodetic monitoring, onshore and offshore surveys, and numerical modelling studies, have been well-developed (e.g. Briole et al, 1995; Armijo et al, 1996; Rigo et al. 1996; Collier et al., 2000; Cornet et al., 2004; Pantosti et al., 2004; Koukoulevas et al., 2005; Leeder et al., 2005; Bernard et al.2006; McNeill et al., 2007; Jolivet et al., 2010; Bell et al., 2009, 2011; Taylor et al., 2011; Pérouse et al. 2012; Pechlivanidou et al., 2019; De Gelder et al., 2019; Fernández-Blanco et al., 2019a,b). They are dedicated to both surface impacts of active tectonics and crustal scale fault-mechanics. 
Offshore surveys focused on recent sedimentary reworking phenomena and their possible relationships with active tectonics and seismicity (e.g. Ferentinos et al., 1988; Papatheodorou and Ferentinos, 1997; Papadopoulos, 2003; Lemeille et al., 2004, Moretti et al., 2004; Stefatos et al., 2004; Campos et al., 2013a; Beckers et al., 2017, 2018). Effects of Late Quaternary climatic cycles on the bounding topographic relief also impacted the rift sedimentary infilling (Watkins et al., 2019). Differences between marine phases of deposition (e.g. interval $\sim 13$ kapresent) and (semi-)isolated (SI) phases of deposition (e.g. interval 70-13 ka) have been clearly documented (e.g. Campos et al., 2013a; McNeill et al., 2019a and b), with sedimentation rates being generally lower, and bioturbation and organic carbon concentration higher, during marine intervals (McNeill et al., 2019b). The occurrence of sedimentary events, specifically turbidites and turbidite-homogenite $(\mathrm{TuHm})$ deposits, have been previously described within the youngest marine and SI units (Campos et al., 2013a, 2014), but little is known about the detailed depositional mechanisms of these sedimentary events, and how they related to earthquakes and/or tsunamis. In this study we aim to characterize the turbidite and TuHm deposits of the IODP 381 Corinth Rift cores using high-resolution X-Ray tomography, in combination with grainsize, magnetic and XRF measurements, to better resolve their depositional mechanism and potential relationship to paleo-earthquakes/tsunamis.

\section{2-Turbidites, homogenites, and turbidites+homogenites.}

\section{2-1- Background}

Relationships between hyperpycnal sediment-carrying flows and specific sediment layers were established half-a-century ago, following in situ observations, measurements and laboratory analyses of outcropping deep-water formations (Bouma, 1962). Different models were proposed following the "Bouma sequence" which described the internal subdivisions of individual turbidite beds (e.g. Talling et al., 2012). Layers partially differing from the initial scheme have also been related to concentrated, particle-laden, gravity flows (e.g. in Lowe, 1982; Stow, 1992; Stow and Wetzel, 1990). The significance of the initial internal subdivisions of a turbidite sensu Bouma sequence has been questioned by several authors, both with regards to the mechanical processes involved as well as applications to the layers that are unrelated to gravity-driven hyperpycnal flow issued from a fluidized slump (e.g. Shanmugan, 1997). Hyperpycnal prolongation of flooding from a river discharge may produce an apparent "turbidite", and thus should not be considered as gravity-reworking event (e.g. Arnaud et al., 2002; Beck, 2009). 
High resolution surveys, both in marine and lacustrine settings (imaging and coring), have pointed out another type of reworking deposit consisting of anomalously thick, only finegrained, homogeneous sediment. These "unifites" (Stanley, 1981) or "homogenites" (Kastens and Cita 1981; Cita et al., 1996; San Pedro et al., 2017; Polonia et al., 2013) were interpreted as resulting from tsunami wave bottom impacts, and/or to seiche effects within a confined setting (e.g. Chapron et al., 1999, Mulder et al., 2009).

Additionally, for both marine and lacustrine settings, different investigations have described both 1) turbidites displaying a sharp transition between the coarse, fining upward, lower part ( $c f$. basal sub-unit of the Bouma sequence), and the homogeneous fine-grained upper sub-unit, and 2) incomplete turbidites associated with a homogenite (Siegenthaler et al., 1987; Sturm et al., 1995; Beck et al., 2007). Both cases are inferred to represent a unique instantaneous sedimentary event - named "homogenite+turbidite" - where the settling of the final fine-grained suspension requires an additional process apart from the final and/or distal damping of a single bottom monophasic turbidity current. The link of homogenite deposition with tsunami waves and/or seiche effect is based on sediment textural analyses (Chapron et al., 1999; Beck et al., 2007; Campos et al., 2013b) and on exceptional post-earthquake in situ surveys (Thunell et al., 1999; McHugh et al., 2011; Lorenzoni et al., 2012). Very remote strong earthquakes (e.g. impact of 2011 Tohoku event on the Gulf of Corinth) may also induce seiche effect in isolated basins (Canitano et al., 2017 and references therein). In some cases, evidences of to-and-fro bottom currents have been observed between the two major terms of homogenites+turbidites (Beck et al, 2007; Campos et al., 2013a), represented by thin silty laminae at the base of a single homogenite (Chapron et al, 1999).

Sharp grainsize breaks within sedimentary events, as in turbidite + homogenite deposits, have also been described in relation to a bimodal grain-size distribution within a flow (e.g. Kane et al., 2007), reflective flows (e.g. Pickering and Hiscott, 1985), flow separation due to topographic obstacles (Sinclair and Cowie, 2003), vertical flow stratification (Gladstone and Sparks, 2002) and fluctuations in flow capacity (Kneller and McCaffrey, 2003), although none of these cases would result in characteristic homogeneous fine-grained upper part of the deposit (see models in Stevenson et al., 2014). Alternatively, fluid mud layers can hinder the settling of non-cohesive grains and bypasses them downslope, to form deposits with sand sharply separated from structureless mud, with the mud thickness increasing towards topographic lows (Stevenson et al., 2014). We note that such a model could result in deposits similar to turbidites/homogenites without necessarily implying gravity reworking. Turbidite lofting resulting from suspension clouds in relation to hyperpycnal flows (Zavala et al., 2011), 
or "dilute plume" river deposition (Hizzett et al., 2018; Hage et al., 2019) could also result in sand-mud couplets with sharp transitions, but are typically more rhythmic in nature and more abundant in plant remains than surge-like gravity reworking deposits (Zavala and Acuri 2016).

\section{2-2- Criteria and nomenclature for sedimentary events.}

Based on the different types of sedimentary reworking events described in the previous section, we adopted a simplified nomenclature for our core descriptions and analyses. Apart from "background" hemipelagite, we distinguished: turbidites, homogenites, and their association homogenite+turbidite $(\mathbf{H m T} \mathbf{T})$. We first distinguished and selected these sedimentary "events" on the basis of visual observations of split cores and corresponding Xray images. We applied commonly used criteria such as: upward grain-size evolution, planar $v s$. oblique stratification, and style of cross stratification. Special attention was paid to: 1) the transition between the coarse sub-unit (bed-load deposition) and the upper fine-grained subunit (suspended load deposition), and 2) the occurrence (or not), at this transition, of an intermediate sub-unit indicating bottom water and particle to-and-fro movements. Although the term "hemipelagite" usually concerns marine deposits, in this study we apply it for slow background sedimentation during both marine and "(semi-)isolated" (SI) environments. In the following text, we use 'units' for the different parts of HmTu beds, and sub-units for, for the different parts within a turbidite or homogenite unit.

\section{3-Data acquisition and processing}

Observations and measurements discussed in this section are based on 1) part of the observations and analyses performed by the whole IODP Expedition 381 science team in the GEOMAR laboratory (Bremen) during the Onshore Science Party (OSP; February 2018; McNeill et al., 2019a), and 2) processing of specific selected post-cruise samples (Fig. 2). Specifically, we sampled 8 U-Channels from the cores of Holes M0078B and M0079A located at sites M0078 and M0079 respectively (Fig. 1) and 9 intervals with spatula samples, half from the most recent marine interval ( 13-0 ka) and half from the upper portion of the most recent SI interval ( $\sim 25-13 \mathrm{ka})$. In total, these samples comprise 8 events from the marine interval, and 10 from the SI interval.

We illustrate and describe our results using representative U-channels 4 and 6 (Fig. 2), with results from the other U-Channels and spatula samples are presented in the Supplementary 
Material. Preliminary results of the whole OSP and raw data of IODP Expedition 381

(Expedition Report) are accessible on http://www.ecord.org/expedition381/.

\section{3-1- Non destructive analyses}

3-1-1- Volume magnetic susceptibility (MS).

To constrain MS within sedimentary events we used two sets of measurements; 1) part of the initial IODP MSCL GEOTEK ${ }^{\mathrm{TM}}$ core logging data (GEOMAR laboratory, Bremen) recorded on the whole cores at $2 \mathrm{~cm}$ resolution, and 2) $0.5 \mathrm{~cm}$ resolution measurements made on $\mathrm{U}$ channels using a BARTINGTON ${ }^{\mathrm{TM}}$ MS2 contact sensor (ISTerre Laboratory, Savoie-MontBlanc University).

\section{3-1-2- X-ray fluorescence (XRF)}

To decipher the chemical composition of sedimentary events we use two sets of XRF measurements (AVAATEC ${ }^{\mathrm{TM}}$ device): 1) whole-core measurements with $5 \mathrm{~mm}$ spacing obtained using the XRF-scanner in Marum Bremen on the intervals of the undisturbed half of the split cores corresponding to all U-channels, and 2) high resolution profiles (1 mm spacing) performed in EDYTEM Laboratory (Savoie-Mont-Blanc University) on four of the retrieved U-Channels.

As XRF analysis does not provide absolute chemical compositions, but relative activity of concerned elements, binary ratios of selected elements are used to characterize the variations of sediment compositions, following Croudace et al. (2006). We specifically selected 24 ratios from the overview of Rothwell and Croudace (2015) that may decipher changes in 1) biogenic/detrital sedimentation, 2) sedimentary provenance, and grainsize, 3) productivity and post-depositional alteration, and 4) organic content. We note that the most of the source area for the Gulf of Corinth deposits are carbonate dominated, so Ca ratios need to be carefully interpreted. We applied Principal Component Analysis (PCA) to these ratios in order to determine: i) the relative importance of different principal components to the overall variation in XRF values, and ii) the specific XRF ratios responsible for most significant changes within a principal component (Supplementary Fig. 1). We show only these most important elemental ratios within the results section, i.e. those with the highest relative contributions to principal components.

3-1-3- Anisotropy of Magnetic Susceptibility (AMS).

To measure AMS within the U-channels we extracted juxtaposed, $2 \mathrm{~cm}$-side, oriented cubes of sediments and measured those using an $\mathrm{AGICO}^{\mathrm{TM}}$ MFK1-FA Kappabridge (automatic spinning, 64 orientations per sample) at the Institut de Physique du Globe de Paris. Following 
the classification of Jelinek (1981) we consider the following parameters: foliation, lineation, shape parameter $\mathrm{T}$, corrected anisotropy degree $\mathrm{Pj}$, inclination of $\mathrm{Kmin}$ ellipsoid axis and the declination of Kmax ellipsoid axis.

3-1-4- 2D X-ray images

X-ray images of all U-channels have been achieved in EPOC Laboratory (Bordeaux University) using the SCOPIX device and procedure (Migeon et al., 1998).

3-1-5- X-ray microtomography.

High-resolution 3D X-ray imaging has been performed on few, $2 \mathrm{~cm}$-side, oriented cubes (as tests), and on $20 \mathrm{~cm}$-long portions of U-channels. We used an EASYTOM ${ }^{\mathrm{TM}}$ XL Nanofocus tomograph located in Grenoble-Alpes University. The source is a tungsten filament producing a source beam of $\sim 3.5 \mu \mathrm{m}$ in diameter. The receiver is a flat panel of $1840 \times 1456$ pixels. Helicoidal recording allowed scanning lengths up to $20 \mathrm{~cm}$ within a single acquisition in about 5 hours. Reconstruction of the tomographic volume was done with RX-Solution's X-act software. This procedure permitted 3-D imaging of density within the scanned volume at a 12 $\mu \mathrm{m}$ voxel size. In the latter analysis, we simply use intensity of gray in the image as a proxy of density. Processing of the scanned images was performed twice with two independent softwares, ImageJ for thresholding and segmenting the grains and the Python scikit-image package.

The fine resolution of the microtomography at the $10 \mu \mathrm{m}$ - scale allows a detailed characterisation of turbiditic sequences, but on length spans not exceeding $20 \mathrm{~cm}$. Since X-ray micro-tomography data is sensitive to the density of the material, we used X-ray data in two different ways: (1) by getting a continuous recording of density profile (we use gray intensity as a proxy for this quantity) by averaging density along a selected band and (2) by segmenting out the heavy grains suspended within the clayish matrix and characterization of their morphological properties. Heavy grains are segmented slice by slice through thresholding and we performed shape analysis to retrieve their size, orientation, and shape ratio. This analysis allows us to highlight the distribution of these grains with depth.

\section{3-2- Grain size distribution}

Besides measurements dedicated to textural analysis of the grain array (§ 3-1-3, 3-1-4, 3-1-5), we made additional observations (optical microscopy) and grain size measurements on individual samples.

We performed Laser microgranulometry using a MALVERN ${ }^{\mathrm{TM}}$ Sizer 2000 apparatus (ISTerre Laboratory, Savoie-Mont-Blanc University) on both 1) individual "spatula" 
samples selected during the IODP Leg 381 OSP (Marum, Bremen), picked at variable spacing of 0.5 to $5 \mathrm{~cm}$, and 2) samples extracted from the U-channels at spacing of 0.5 to 2 $\mathrm{cm}$.

\section{3-3- Chronological control}

For our purposes we only require an approximate chronology, for which we follow the general chronostratigraphy deduced from correlation between core data and seismic reflexion profiles. Seismic stratigraphy is interpreted according to Late Quaternary sea-level fluctuations and their impact on the Gulf of Corinth. The investigated intervals of this study (Fig. 2) correspond to the last alternation of marine and (semi-)isolated environments. Previous radiocarbon dating and correlation with sea-level curves places the transition between those environments at $12-13 \mathrm{ka}$ (e.g. McNeill et al., 2019a). Assuming that sedimentation rates between this transition and the underlying marine sub-unit ( $\sim 70 \mathrm{ka}$; McNeill et al., 2019a) have been constant, we estimate our oldest U-Channels to be around $\sim 25 \mathrm{ka}$.

\section{4-Results}

Below we present our results of our detailed work on the U-channels and spatula samples. Note that additional results are presented as Supplementary Material.

\section{4-1 Layering and composition}

The investigated core portions (down to $65 \mathrm{mbsf}$ in borehole M0079A) display a clear layering with alternating dark grey to whitish, essentially fine-grained sediments (silty clay/clayey silt). Minor coarser material (very fine sand to rare medium sand with a clayeysilty matrix) with higher siliciclastic content is present along the whole succession. Individual layers are mm- to tens of $\mathrm{cm}$-thick ( $c f$. close ups on Fig. 2), resulting from the intercalation of different types of event layers within a fine-grained "background" sedimentation consisting of hemipelagic deposition. Fine-grained facies are calcareous muds where the carbonate fraction is biogenic or detrital. In the marine interval primary biogenic components mostly consists of nanoplankton and rare planktonic forams, whereas in the SI intervals it mostly consists of calcite and diatoms. Detrital grains are mostly calcite for both intervals. The silt- and clay-size siliciclastic fraction is made of calcite,, clay minerals, quartz and altered ferromagnesian debris. Aragonite needles also occur, especially in the transition between marine and SI units.

In the following, we refer to sedimentary events as classical turbidites or homogenite+turbidite (Hm Tu). Figure 3 illustrates the two types of events, particularly 
different in the nature of the transition between a coarse (even polyphasic) fining upward lower unit and a highly homogeneous fine grained upper unit. The transitions between homogenites and their overlying hemipelagic intervals were based on texture (§ 4-2) and XRF chemistry (§ 4-3); for several events it could be compared with X-ray 3D microtomogaphy data $(\S 4-6)$.

\section{4-2 Grain-size distributions of fine-grained layers}

Sampling for homogenite and hemipelagite grain-size characterization was based on visual observations of the split cores from boreholes M0078B and M0079A. We selected Uchannels 1, 2, 5, and 6 within the marine environment, and U-channels 3, 4, 7, and 8 within the SI environment. To characterize each marine and SI homogenite or hemipelagite sample, we use the D50 (or median) and the D99 that represent the "mean" grain size and the coarsest grain size fraction, respectively (Fig. 4-A to D), and two grain analysis parameters, sorting and skewness (Fig. 4-E to H). The eight binary cross-plots of these two parameters shown in Figure 4 allow us to investigate: 1) possible differences between hemipelagites and homogenites, and 2) possible influence of the depositional environment (i.e. marine or SI) on both.

Figure 4A-D do not show significant differences neither between the two types of units nor between the two environments; in both cases, hemipelagite values appear slightly more dispersed. Regarding distribution parameters sorting and skewness, all samples depict values between 0.8 and 1.2 for skewness and between 1.7 and 2.5 for sorting, except for a few samples of marine hemipelagites (Fig. 4-E and $-\mathrm{G}$ ). There are both marine hemipelagite samples that display a very good sorting $(<1.5)$ and samples that show a weak sorting $(>2.5)$ and a highly asymmetric distribution. Homogenites do not appear significantly different in marine or SI units. For both environments, homogenite samples appear slightly less dispersed than hemipelagites, and SI homogenites display a similar range of values for sorting and skewness with respect to SI hemipelagites (Fig. 4).

\section{4-3. Distributions of XRF chemical parameters}

Figure 5 summarizes results from all U-channels with separate distributions for hemipelagites, homogenites and turbidites. Supplementary Figure 2 shows additional XRF counts and Supplementary Figure 3 shows the 24 detailed XRF ratios of all U-channels as a function of depth. We highlight the following main characteristics. 
- In terms of biogenic/detrital origin (Fig. 5-a and-c), chosen XRF chemical parameters discriminate the three types of units. Turbidites and homogenites have relatively similar ratios, with the exception of $\mathrm{Ca} / \mathrm{Fe}$ that is generally lower in homogenites. Homogenites have lower $\mathrm{Ca}$ ratios than hemipelagites $(\mathrm{Ca} / \mathrm{Fe}, \mathrm{Ca} / \mathrm{Ti}, \mathrm{Ca} / \mathrm{Sr})$, indicating a generally higher detrital content. The $\mathrm{Ca} / \mathrm{Sr}$ ratio in SI conditions (Fig. 5c) is the only exception, and combined with the decrease in $\mathrm{Ti} / \mathrm{Sr}$ ratios as well as the overall increase in Sr for the SI U-channels (Suppl. Fig. 2), this suggests that the increased Sr during SI conditions affects hemipelagite composition more than turbidite and homogenite composition.

- In terms of organic content (Fig. 5-b and -d), turbidites, homogenites and hemipelagites have a similar range of values, with the main difference that hemipelagites appear to have mostly a bimodal distribution. The overall lower $\mathrm{Br} / \mathrm{Cl}$ ratios during SI conditions is in line with the overall Br decrease (Suppl. Fig. 2).

- In terms of sedimentary provenance/grainsize (Fig. 5-e and -g), turbidites show a larger variation with respect to homogenites and hemipelagites, which may be partly due to varied terrigenous sources and/or to larger grain size. Homogenites display a generally narrow range of values, indicating chemical and mineralogical homogeneity with respect to hemipelagites, which generally have a skewed distribution. We note that peak values for $\mathrm{Zr} / \mathrm{Rb}$, Ti/Rb and $\mathrm{Zr} / \mathrm{K}$ in homogenites are slightly lower than hemipelagite peak values during marine conditions, but slightly higher during SI conditions. Given that homogenite values remain relatively constant, this suggests a slight change in the overall mineralogical composition of hemipelagites.

- In terms of productivity and post-depositional alteration (Fig. 5-f and -h), Br/Ti ratios appear slightly higher and more variable during marine conditions for all three types. Concerning S/Ti ratios, homogenites seem to have slightly lower values than those obtained for turbidites and hemipelagites.

Overall these observations show that turbidites, homogenites and hemipelagites have distinct chemical characteristics and that there are some differences in chemical composition between marine and SI depositional environments, particularly within hemipelagites.

\section{4-4. Correlations of geochemical, magnetic and textural parameters}


XRF and textural parameters are presented for U-channels 4 and 6 (Figures 6a,b and $7 \mathrm{a}, \mathrm{b}$, respectively); the same measurements applied to the other U-channels are available in Supplementary Figure 4, and detailed event description in Supplementary Table 1.

In U-channel 4 (Fig. 6) we observe five different sedimentary events, based on a gradual vs. sharp transition between turbidites and an overlying fine grained sub-unit we refer to events 1 and 5 as classical turbidites (Tu), and events 2, 3 and 4 as turbidite-homogenite deposits (TuHm). Grainsizes are especially high for events 2 and 5, with respective D50 values of 30 and $50 \mu \mathrm{m}$, which are also the thickest events in this $U$-channel $(5-10 \mathrm{~cm})$. The peak in magnetic susceptibility at the top of event 5 corresponds to a cluster of black grains that seem to be the result of postdepositional alteration. AMS foliation is particularly high in the homogenites of events 2 and 4, with the lineation overall low apart from a gradual increase within event 5 . The Kmin inclination is close to vertical, indicating relatively flatlying grains, and the Kmax declination is strongly variable, indicating no strong preferred orientation of grains in the horizontal plane. Looking at the XRF ratios, the $\mathrm{Ca} / \mathrm{Ti}$ and $\mathrm{Ca} / \mathrm{Fe}$ ratios are generally lower within sedimentary events, and show sharp changes around transitions with hemipelagic intervals. $\mathrm{Zr} / \mathrm{Rb}$ is particularly high in turbidites, sharply decreasing upwards within TuHm events 2 and 4, and a more gradual decrease within Tu event 5. The separation between two homogenite intervals ( $\mathrm{Hm} 1$ and $\mathrm{Hm} 2)$ in events 2 and 4 is particularly clear from core images and X-rays, and for event 2 this sharp change is also expressed in changing $\mathrm{Ca} / \mathrm{Ti}, \mathrm{Ca} / \mathrm{Fe}$ and $\mathrm{Fe} / \mathrm{Si}$ ratios.

U-channel 6 (Fig. 7) only contains one $\sim 19 \mathrm{~cm}$ thick sedimentary event. All selected XRF ratios display highly variable values within the lower turbidite interval between 20.26 and $20.22 \mathrm{mbsf}$, and show similar trends to grain size variations. The top of the event at $20.06 \mathrm{mbsf}$ is marked by a sharp shift of $\mathrm{Ca} / \mathrm{Ti}, \mathrm{Ca} / \mathrm{Fe}, \mathrm{Ca} / \mathrm{Si}, \mathrm{Cu} / \mathrm{Rb}$, and $\mathrm{Mn} / \mathrm{Ti}$ ratios (Fig. 7 and Suppl. Fig. 4). The visually detected subdivision of the homogeneous mud interval, interpreted as $\mathrm{Hm}$, is confirmed by slight changes of $\mathrm{Ca} / \mathrm{Ti}, \mathrm{Ca} / \mathrm{Fe}, \mathrm{Ca} / \mathrm{Si}, \mathrm{Si} / \mathrm{Ti}, \mathrm{Fe} / \mathrm{Rb}$, and Fe/Ti (Hm1 and Hm2 in Fig. 7), similarly to event 4, but not to event 2 in U-Channel 4 (Fig. 6). The volume magnetic susceptibility is overall low, but higher in the finer-grained intervals than in the coarse base. Magnetic susceptibility roughly follows the same trend as the Fe/Si ratio indicating a likely control of this parameter by the relative proportion of quartz versus iron oxides. Whereas magnetic susceptibility is constant in $\mathrm{Hm} 1$, it shows slightly more variation in $\mathrm{Hm} 2$ possibly due to heterogeneities associated with larger grains.

The entire homogenite interval in U-Channel 6 (Fig. 7), displays a higher magnetic foliation with respect to the overlying hemipelagic layer and with respect to the coarse 
turbidite base. Shape parameter T (oblate ellipsoid distribution), lineation, Kmax declination and Kmin inclination (vertical) do not display clear changes between the different deposit types. When looking at the Hm interval in more detail, we note a change in magnetic foliation around the $\mathrm{Hm} 1 / \mathrm{Hm} 2$ separation. Grain-size distribution also underlines this contrast in the D99, but within suspended-load ranges.

\section{4-5. X-ray micro-tomography data}

4-5-1- Quantitative measurements

Selected portions imaged through X-ray micro-tomography for U-channels 4 and 6 are presented on Figures $6 \mathrm{c}, \mathrm{d}$ and 7c, respectively with correlation to the detailed XRF profiles. The same measurements applied to U-channels 2 and 8 are available in Supplementary Figure 4. We show the averaged density along a band highlighted with green shading, and the morphological properties of the suspended heavy grains with yellow patches (Figure 6 and 7).

The high porosity associated with the turbiditic base has a stronger effect on the density than the general occurrence of heavier grains, so that the turbiditic base generally has a lower density (average pixel value, Figs 6 and 7) than the underlying hemipelagite. The exception is event 5 in U-Channel 4 in which the entire turbidite interval has a higher density than the underlying hemipelagite. Both homogenite profiles with separate $\mathrm{Hm} 1 / \mathrm{Hm} 2$ intervals (events 2 and 4, Fig. 6) have a small offset in density between a slightly heavier $\mathrm{Hm} 1$ and lighter Hm2. Also, in U-Channel 4 (event 2, Fig 6d), heavy grains are clearly scarcer above this transition. In the U-Channel 6 event, the base of Hm1 (Fig. 7c) displays faint fluctuation in grey scale.

Figure 6c shows the occurrence and size of heavy grains (see $\S 3-5$ ) within event 5 , fining up gradually, as expected from a dilute turbidite deposit. Similarly, Figure $6 \mathrm{~d}$ reveals three clear sub-units of coarser laminations with heavy grains at the turbiditic base of event 2 (40.24, 40.235, and $40.21 \mathrm{mbsf})$. The first and second bottom sub-unit were not resolved by the XRF data, but the microtomography indicates that their grains are similar in nature, both in size distribution and orientation. The third sub-unit within this event at 40.21 mbsf is different in nature, with smaller aspect ratio and finer grains. Grains of this sub-unit are notably different from the previous two sub-unitin that there is a predominantly horizontal orientation to the grains. This suggests that the third sub-unit is either related to a secondary deposition phase with a different content, was subjected to different energy/flow dynamics and/or obeying to a depositional mechanism different from the one responsible for the first two sub-units. The turbidite in U-Channel 6 (Fig. 7c) shows three sub-units with heavier 
grains (at $\sim 20.255, \sim 20.237$, and $\sim 20.23 \mathrm{mbsf}$ ), which are only faintly indicated by the XRFratios, but more easily distinguished through microtomography. The lower turbidite sub-unit has a higher aspect ratio and higher concentration of heavy grains than the other two pulses, again indicating a variability between the different sub-units.

\section{4-5-2 Qualitative observations of sedimentary event structures}

The combination of analyses presented here - with special attention to X-ray microtomography - contributes to our understanding of the origin of material, the detailed layering, and the grain array (especially suspended load). Grain arrays were previously measured using core images and physically "blind" characterization like AMS. Here we benefit from more direct views of the grain array using high-resolution 3D microtomography particularly for u-channel portions that contrast in density. Figure 8 shows zoom-ins of sedimentary structures, with additional X-Ray microtomography images for U-Channels 2 and 8 are shown in Supplementary Fig. 5. Focusing on the basal surface, internal basal turbiditic structure, and the base of the homogenite interval, we highlight several key observations.

- The irregular shape of the turbiditic interval base for the thickest observed HmTu events (Fig. 8b), and more subtly the microfractured base of events 2 and 4 of $U-$ Channel 4 (Fig. 8a). In contrast, the single thinner Tu event in U-Channel 4 (Fig, 8a, event 5) displays a smooth planar surface. This difference may be explained by more friction at the base of the turbid flow versus a total decoupling, or by variable erosion in relation to energy of the flow. For U-Channel 4 event 2 (Fig. 8a), below the base of the homogenite, we observe a deformed interval involving fine-grained and slightly coarser layers.

- A complex distribution of coarser siliciclastic grains in the turbiditic interval base for the observed HmTu events with multiple turbiditic laminations (Fig. 8). Based upon HmTu events investigated here, this structure appears complex, including several microfractured intervals within the coarser-grained portions of the sedimentary events. These intervals have transitional bases and tops, which also correspond to downward and upward reduction and eventual disappearance of the microfractures. This suggests that microfracturing developed only within sub-units having a favourable rheology (grain-size distribution), even if the forces resulting in microfracturing probably also acted on the finer-grained sub-units. 
- The successive occurrence of low-angle cross-bedding in opposite directions in the turbidite of U-Channel 6, particularly clear in middle part of the turbidite (Fig. 8b). We systematically verified the opposite dips in this cross-bedding using $2 \mathrm{D}$ views under multiple angles, excluding the possibility that the dips are ripple/dune structures that only appear opposite under certain viewing angles.

\section{5- Discussion: inferred depositional mechanisms of sedimentary events}

\section{5-1 The classical view: from grain size analysis, AMS and XRF studies}

Grainsizes are consistently fining upwards within all studied turbidites, and we emphasize that gradual or sharp changes clearly mark the difference between turbidite and HmTu sedimentary events, respectively (Fig. 4). Similar to previous studies (e.g. Rothwell et al., 2006; Konfirst et al., 2011), we find that $\mathrm{Zr} / \mathrm{Rb}$, Si/Al and Fe/Si appear to be useful chemical proxies for grainsize, showing very similar trends to D50/D99 (Figs. 6 and 7; Supplementary Fig. 3). Our XRF results are generally in agreement with those of Campos et al. (2014) for nearby sedimentary core MD01-2477 (Fig. 1), that show $\mathrm{Ca} / \mathrm{Fe}, \mathrm{Ca} / \mathrm{Ti}$ and $\mathrm{Ca} / \mathrm{Si}$ as good indicators of homogenites. As such, although most of the catchment in the Corinth Rift is carbonate-dominated (e.g. Gawthorpe et al., 2017), the overall lower Ca content of the reworked sediments suggests a higher siliclastic detrital content for event beds compared to the more biogenic hemipelagites. Homogenites content may represent either allochtonous material or in situ reworking (re-suspension and re-settling) of fine-grained content; the difference in composition between homogenites and hemipelagites favours the former.

Our AMS results are also similar to previous findings (Campos et al., 2013b; Maffione and Morris, 2017) in the sense that homogenites are characterised by high foliation (Figs. 6; 7) and corrected anisotropy degree Pj (Supplementary Fig. 4). For future work on sedimentary events in the IODP-381 cores, the XRF results appear particularly useful given its ability to help distinguish $>2 \mathrm{~cm}$ thick turbidites and homogenites from hemipelagites (Figs. 5, 6, 7) and its availability at $2 \mathrm{~cm}$ resolution for most of borehole M0079A (McNeill et al., 2019a).

In addition to confirming previous findings using classical parameters, as mentioned above, our detailed microtomographic analysis highlights two novel observations: firstly, lower Tu parts with complex, multilayered, coarse with overall normal graded bedding, appear to be rule rather than exception. Given the scale of the analysis, Campos et al. (2013a) could not resolve this in a study on comparable deposits within the Corinth Rift. Secondly, several homogenite sections of HmTu events can be subdivided into multiple intervals. This subdivision is different from previously published cases where a homogenite gradually and 
changes upwards from faintly layered to structureless (e.g. Beck et al., 2019). Here, the transition (Hm1/Hm2 on Fig. 6, 7C and D) involves sharp changes in chemical and textural parameters. We briefly discuss these two findings in the following section.

\section{5-2 A more complex view from fine X-ray tomography images}

Although our results concern short portions of selected sedimentary events, both the turbiditic base and the overlying homogenite of a $\mathrm{HmTu}$ deposit reveal a detailed complexity when imaged through X-ray microtomography (Figs. 8 and 9).

Concerning basal parts of $\mathrm{HmTu}$, we highlight, from base to top: 1) the occurrence of complex basal surfaces. We interpret the curved shapes to be formed by erosion of a dense coarse flow; due to the small size of the U-channel, only part of a groove cast-type surface may have been crossed (Fig. 9a). We interpret the planar subvertical shape as microfractures of the underlying mud, before the arrival of the basal turbidite (Fig. 9a). Following the criteria in McNeill et al. (2019b), we prefer this interpretation over drilling induced fractures as they are planar and do not appear influenced by the core liner or core axis orientation. In our studied core sections, we did not observe liquefaction or fluid escape features (Fig. 9a), as mentioned elsewhere at the turbidite/hemipelagite interface (e.g. Beck et al, 2007); 2) within the coarser grained lower part of U-Channel 6 (Fig. 8b), we observe clear low angle crossbedding (in 2D and 3D). Classical schematic subdivision of turbidites (e.g. Bouma, 1962) often indicates, in this position, climbing ripples following a unique flow direction. Here, we interpret successive opposite directions as an effect of complex flowing patterns similar to previously described to-and-fro intervals (Campos et al., 2013a) or reflected turbidites (Pickering and Hiscott, 1985); 3) faint turbidite layering, related to progressive grain-size distribution changes. In two cases (event 2 in U-Channel 4, Fig.8a and the event in U-Channel 6, Fig. 8b), microfractures are concentrated within the coarser sub-units.

As mentioned in $\S 4-4$ and 5-1, several homogenite sections of HmTu events appear to consist of separate sub-units on split core surface and X-ray images (U-Channel 4 (40.04 and 40.175 mbsf, events 2 and 4, Fig. 6); and U-Channel 6 (20.15 mbsf, Fig. 7 (as well as UChannels 2, 5, 7 and 8; Supplementary Figs. 3, 4, and Supplementary Table 1)). The XRF profiles show changes between the homogenite sub-units, but not in a consistent manner in the three examples in U-Channels 4 and 6. X-ray microtomography add two observations concerning the Hm-subdivision: subtle density differences between the homogenite sub-units in U-Channel 4 (Fig. 6), and faint laminations at the base of the lower homogenite sub-units in U-Channel 6 (Fig. 7). We relate the homogenite subdivision to two settling phases: initial 
high-density suspension behaviour followed by longer lasting settling from a stable suspension. The observed XRF and structural variations imply that non-uniform settling is guided by the composition of the initial suspension and slight segregations among suspended particles (Fig. 9b, case B).

Details displayed by X-ray microtomography also question the location of the $\mathrm{Tu} / \mathrm{Hm}$ transition, especially for event 2 of U-Channel 4 (Fig. 8a) and U-Channel 6 (Fig. 8b). In UChannel 6, two similar fine-grained sub-units overlie cross-stratified coarser laminations. The lower one may represent a $\mathrm{Hm} 1$, overlain by a $\mathrm{Hm} 2$, as mentioned above, and interpreted as a change in settling (intrinsic cause; e.g. evolution from a high density suspension to lower density one). We propose a similar interpretation for the faint layering within U-Channel 4 event 4 (Fig. 9b, case B). The soft sediment deformation within U-Channel 4 (event 2; Fig. 8a), which we interpret as slumping, occurred after the beginning of suspension settling; this disturbed sub-unit may be considered as part of the homogenite (Fig. 9b case C, and Fig. 9c). This feature, as well as microfractures within the turbiditic unit and possibly within a transition interval (Fig. 9c), clearly represents a post-turbidite disturbance. If the initial turbidite was earthquake-related, this post-turbidite disturbance may be related either to ongoing strong oscillations or to new shaking events, possibly aftershocks.

Several authors have described, at the $\mathrm{Tu} / \mathrm{Hm}$ transition, coarser lamina which they relate to "sweeping" on lateral slopes (e.g. Chapron et al., 1999); such slope "sweeping" has been clearly demonstrated for major subduction earthquakes+tsunamis, using short live radiogenic isotopes (McHugh et al., 2016). For large closed basins, a sharp thermocline may be affected by internal Kelvin waves that erode soft sediments where the thermocline impinges on the slope (e.g. Bouffard and Lemmin, 2013). This process may have played a role as well within the Gulf of Corinth (Fig. 9b, case D), to explain complexities observed within homogenite deposits.

As mentioned before ( $§ 2-1)$, the sharp grainsize breaks within the sedimentary events we named TuHm can also be interpreted as the result of turbidite lofting (Zavala et al., 2011) or fluid mud layers that hinder the settling of non-cohesive grains and bypasses them down slope (Stevenson et al., 2014). For the larger events studied in detail, like event 2 in U-Channel 4 $(\sim 10 \mathrm{~cm})$ and the event in U-Channel $6(\sim 20 \mathrm{~cm})$, we find an earthquake/tsunami origin the most straightforward interpretation, given the complex turbidite base, microfracturing and evidence for ongoing oscillations. Contrarily, for less well-resolved, smaller events like event 3 in U-Channel 4 ( $\sim 2 \mathrm{~cm}$ ) we consider non-earthquake origins (e.g. river flooding) similarly possible. In future work, one possible way to help distinguish the depositional mechanism is 
to look in more detail to organic content within the sedimentary events (Zavala and Arcuri, 2016).

\section{5-3 Possible effect of environments on sedimentary event structure/composition}

All previous remarks on specific layers ( $(5-1$ and 5-2) can also be discussed within the context of two depositional environments; marine and (semi-)isolated. In neighbouring Core MD01-2477, although only covering $\sim 6$ ka of the (semi-)isolated interval, Campos et al. (2013a) mention generally thicker sedimentary events within the marine interval with respect to the underlying SI interval. They tentatively attribute this tendency to more available detrital material in source areas; the authors consider that erosional products may have been stored during LGM, and mobilized later during the Holocene. With an average $13 \mathrm{~cm}$ for the 9 marine sedimentary events and $12 \mathrm{~cm}$ for the 10 SI events we cannot observe such a trend within our limited number of samples, but the hypothesis of thicker events during marine periods can be easily tested in a future study on sedimentary event size and frequency over a larger section.

Concerning the combined thickness of sedimentary events and hemipelagic deposition, McNeill et al. (2019b) showed on the longer IODP-381 cores that sedimentation rates and the input of coarse material (sands, silts) are generally lower during marine than in SI intervals. Similar to Collier et al. (2000), they conclude that both reduction and change of vegetation cover led to stronger soil erosion and higher sediment flux into the basin during the SI intervals. In the core portions investigated here, we find two major differences for the sedimentary events between marine and SI environments: 1) Higher $\mathrm{Sr}$ and $\mathrm{Sr} / \mathrm{Ti}$ concentrations within the SI interval (Fig. 5 and Supplementary Fig. 2), particularly for hemipelagic sedimentation. We relate this to the aragonite needles occurring more frequently within the SI interval than in the marine interval, especially in the transition from marine to SI environments (Campos, 2014; McNeill et al., 2019a,b). Their occurrence is a possible consequence of either in situ mixing of marine and fresh water, or precipitation in shallow areas and subsequent remobilization and transport (Moretti et al., 2004; Lykousis et al., 2007); 2) Hemipelagites seem to be more sensitive to environmental changes than homogenites, specifically for $\mathrm{Ti} / \mathrm{Sr}, \mathrm{Zr} / \mathrm{Rb}, \mathrm{Ti} / \mathrm{Rb}$ and $\mathrm{Zr} / \mathrm{K}$ (Fig. 5). This suggests that similar fine-grained deposits are reworked during both marine and SI conditions, despite changes within in situ hemipelagic deposition. Despite these observed differences, we consider that to a first order, the depositional processes inferred for sedimentary "events" are similar in marine and SI environments in terms of thickness, structure and composition. 


\section{Conclusions and perspectives}

The main goal of our present investigation is to improve our understanding of sedimentary event deposits in the Central Gulf of Corinth during the last $\sim 25 \mathrm{ka}$, using a combination of grainsize, magnetic and chemical parameters with high-resolution X-Ray microtomography. We highlight the following outcomes of our analyses.

1) Grainsize, AMS and XRF measurements provide efficient means to decipher sedimentary events (turbidite and TuHm deposits) from hemipelagic background sedimentation for the events recorded within boreholes M0078B and M0079A of IODP Expedition 381. X-Ray microtomography is complementary to those measurements as it provides observations of density and texture differences down to the grain-scale.

2) X-Ray microtomography evidences the complexity of basal turbidites within a sedimentary event. Through 3D imaging we can detect microfractures and erosional features relating to basal surface, and multiple coarse-grained turbiditic sub-units (Fig. 9) which we interpret as expressions of complex gravity flows. Successive crossbedding in $\sim 180^{\circ}$ opposite directions is interpreted as indicative of water mass oscillations typical for tsunami/seiche effects or due to turbidite reflection within the enclosed Gulf.

3) X-Ray microtomography helps detecting the occurrences of faint layering (sometimes folded) within homogenites, possibly related to discrete changes in composition and grain-size. We interpret these features as indications of intrinsic settling fluctuations, ongoing water mass displacement during homogenite deposition and/or the intercalation of coarser material during subsequent gravity flows (Fig. 9b). 4) In terms of environmental influences on sedimentary events, XRF results indicate that turbidites and homogenites are less sensitive to changes between marine and (semi-)isolated conditions than the hemipelagic sedimentation. Within our limited sample size we do not observe major differences in terms of sedimentary event thickness, composition and structure.

In a general sense, X-ray microtomography can document characteristics of all types of sedimentary events to better understand their origins. More specifically, it can provide additional observations that help assist the interpretation of the seismic/tsunami origins, and help achieve a chronicle of regional paleoseismicity, either in the Corinth Rift or elsewhere. 


\section{Acknowledgements}

All authors declare that there are no conflicts of interest in relation to this article. This research used samples and/or data provided by the International Ocean Discovery Program (IODP). Funding for this research was provided by IODP-France. GdG and CS thank IODPFrance for the financial support and postdoctoral scholarship that helped us carry out this research. GC publishes with permission of the Director of the British Geological Survey (United Kingdom Research and Innovation). RLG thanks the VISTA programme of Norwegian Academy of Science and Letters for the award of its VISTA Professorship which also provided support to SP in order to undertake research on IODP Expedition 381, and RLG also acknowledges support from the Research Council of Norway (DeepRift project; number 308805). We thank OSUG@2020 for its contribution to the X-ray microtomography funding and Pierre Lhuissier from the SIMAP laboratory for his help for performing X-Ray tomography acquisition. We thank all IODP-381 expedition members for insightful discussions on a wide spectrum of topics in relation to the Corinth Rift.

\section{Data Availability Statement}

Preliminary results of the whole OSP and raw data of IODP Expedition 381 (Expedition Report) are accessible on http://www.ecord.org/expedition381/. Additional data that support the findings of this study are available from the corresponding author upon reasonable request.

\section{REFERENCES}

Albini, P., Rovida, A., Scotti, O., and Lyon-Caen, H., 2017. Large Eighteen-Nineteen Century earthquake s in Western Gulf of Corinth with reappraisal size and location. Bulletin of the Seismological Society of America, 107(4):1663-1687. doi: 10.1785/0120160181

Armijo, R., Meyer, B., King, G.C.P., Rigo, A., Papanastassiou, D., 1996. Quaternary evolution of the Corinth Rift and its implications for the late Cenozoic evolution of the Aegean. Geophysical Journal International, 126, 11-53.

Arnaud, F., Lignier, V., Revel, M., Desmet, M., Beck, C., Pourchet, M., Charlet, F., Trentesaux,

A.. and Tribovillard, 2002. Flood and earthquake disturbance of ${ }^{210} \mathrm{~Pb}$ geochronology (Lake Anterne, NW Alps). Terra Nova, 14, 225-232.

Beck, C., 2009. Late Quaternary lacustrine paleo-seismic archives in north-western Alps: 
Examples of earthquake-origin assessment of sedimentary disturbances. Earth-Science Reviews, 96:327-344.

Beck, C., Carrillo, E., Audemard, F., van Welden, A., Disnard, J.-R., 2019. Tentative integration of paleoseismic data from lake sediments and from nearby trenches: the central section of the Boconó Fault (northern Venezuela). Journal of South American Earth Sciences, 92:646-657.

Beck, C., Campos, C., Eriş, K.K., Çağatay, N., Mercier de Lepinay, B., and Jouanne, F., 2015. Estimation of successive co-seismic vertical offsets using coeval sedimentary events: application to the south-western limit of the Sea of Marmara's Central Basin (North Anatolian Fault). Natural Hazards and Earth System Sciences, 15:247-259, doi:10.5194/nhess-15-247-2015.

Beck, C, Mercier de Lépinay, B., Schneider, J.-L., Cremer, M., Çağatay, N., Wendenbaum, E., Boutareaud, S., Ménot, G., Schmidt, S., Weber, O., Eris, K., Armijo, R., Meyer, B., Pondard, N., Gutscher, M.-A., and the MARMACORE Cruise Party, J.-L. Turon, L. Labeyrie, E. Cortijo, Y. Gallet, H. Bouquerel, N. Gorur, A. Gervais, M.-H. Castera, L. Londeix, A. de Rességuier, A. Jaouen., 2007. Late Quaternary co-seismic sedimentation in the Sea of Marmara's deep basins. in "Sedimentary Records of Catastrophic Events" (F. Bourrouilh-Le Jan, C. Beck, D. Gorsline, Eds.) Spec. Iss. Sedimentary Geology, 199:65-89.

Beck, C., Reyss, J.-L., Leclerc, F., Moreno, E., Feuillet, N. and GWADASEIS Cruise Scientific Party: L. Barrier, F. Beauducel, G. Boudon, V. Clément, C. Deplus, N. Gallou, J.-F. Lebrun, A. Le Friant, A. Nercessian, M. Paterne, J.-M. Saurel, T. Pichot, C. Vidal, 2012. Identification of deep subaqueous co-seismic scarps through specific coeval sedimentation in Lesser Antilles: implication for seismic hazard. Natural Hazards and Earth System Sciences, 12:1-13, doi:10.5194/nhess-12-1-2012.

Beckers, A., Beck, C., Hubert-Ferrari, A., Tripsanas, E., Crouzet, C., Sakellariou, D., Papatheodorou, G., and De Batist, M., 2016. Influence of bottom currents on the sedimentary processes at the western tip of the Gulf of Corinth, Greece, Marine Geology, 378, 312-332.

Beckers, A., Beck, C., Hubert-Ferrari, A., Reyss, J. L., Mortier, C., Albini, P., Rovida, A., Develle, A.-L., Tripsanas, E., Sakellariou, D., Crouzet, C., and Scotti, O., 2017. Sedimentary impacts of recent moderate earthquakes from the shelves to the basin floor in the western Gulf of Corinth. Marine Geology, 384:81-102.

Beckers, A., Hubert-Ferrari, A., Beck, C., Papatheodorou, G., De Batist, M., Sakellariou, D., 
Tripsanas, E., and Demoulin, A., 2018. Characteristics and frequency of large submarine landslides at the western tip of the Gulf of Corinth. Natural Hazards and Earth System Sciences, 18, 1411-1425, 2018. doi.org/10.5194/nhess-18-1411-2018

Bell, R.E., McNeill, L.C., Bull, J.M., Henstock, T.J., Collier, R.E.L., Leeder, M.R., 2009. Fault architecture, basin structure and evolution of the Gulf of Corinth Rift, central Greece. Basin Research, 21:824-855. doi.org/10.1111/j.1365-2117.2009.00401.x.

Bell, R.E., McNeill, L.C., Henstock, T.J., Bull, J.M., 2011. Comparing extension on multiple time and depth scales in the Corinth Rift, Central Greece. Geophysical Journal International, 186:463-470.

Bernard, P., Lyon-Caen, H., Briole, P., Deschamps, A., Boudin, F., Makropoulos, K., Papadimitriou, P., Lemeille, F., Patau, F., Billiris,H., Paradissis, D., Papazissi, K., Castarède, H., Charade, O., Nercessian, A., Avallone, A., Pacchiani, F., Zahradnik, J., Sacks, S., Linde, A., 2006. Seismicity, deformation and seismic hazard in the western rift of Corinth: new insights from the Corinth Rift Laboratory (CRL). Tectonophysics, 426(1-2):7-30.

Bouffard, D., Lemmin, U., 2013. Kelvin waves in Lake Geneva. Journal of Great Lakes Research, 39(4):637-645. doi.org/10.1016/j.jglr.2013.09.005

Bouma, A.H., 1962. Sedimentology of some Flysch Deposits: A Graphic Approach to Facies Interpretation. Elsevier, Amsterdam, 168 pp..

Briole, P., Rigo, A., Lyon-Caen, H., Ruegg, J., Papazissi, K., Mitsakaki, C., Balodimou, A., Veis, G., Hatzfeld, D., and Deschamps, A., 1995. Active deformation of the Corinth rift, Greece: Results from repeated Global Positioning System surveys between 1990 and 1995, Journal of Geophysical Research, 105 :25605-25625.

Campos, C., 2014. Comparative study of co-seismic sedimentation in two tectonically active areas: the Sea of Marmara and the Gulf of Corinth. PhD, Grenoble-Alpes-University, 302 pp..

Campos, C., Beck, C., Crouzet, C., Carrillo, E., Welden, A.V., Tripsanas, E., 2013a. Late Quaternary paleoseismic sedimentary archive from deep central Gulf of Corinth: time distribution of inferred earthquake-induced layers. Annals of Geophysics, 56:1-15. doi.org/10.4401/ag-6226.

Campos, C., Beck, C., Crouzet, C., Demory, F., Van Welden, A., Eris, K., 2013 b. Deciphering hemipelagites from homogenites through anisotropy of magnetic susceptibility. Paleoseismic implications (Sea of Marmara and Gulf of Corinth). Sedimentary Geology, 292:1-14. doi.org/10.1016/j.sedgeo.2013.03.015. 
Canitano, A., Bernard, P., Allgeyer, S., 2017. Observation and modelling of the seismic seiches triggered in the Gulf of Corinth (Greece) by the $2011 \mathrm{Mw} 9.0$ Tohoku earthquake. Journal of Geodynamics, 109/24-31. doi.org/10.1016/j.jog.2017.06.001

Chapron, E., Beck, C., Pourchet, M., and Deconinck, J.-F., 1999. 1822 earthquake-triggered homogenite in Lake Le Bourget (NW Alps). Terra Nova, 11:86-92.

Charalampakis, M., Lykousis, V., Sakellariou, D., Papatheodorou, G., Ferentinos, G., 2014. The tectono-sedimentary evolution of the Lechaion Gulf, the south eastern branch of the Corinth graben, Greece. Marine Geology, 351:58-75, doi.org/10.1016/j.margeo.2014.03.014.

Cita, M.B., Camerlenghi, A., Rimoldi, B., 1996. Deep-sea tsunami deposits in the eastern Mediterranean: new evidence and depositional models. Sedimentary Geology, 104:155-173.

Collier, R., Leeder, M.R., Trout, M., Ferentinos, G., Lyberis, E., Papatheodorou, G., 2000. High sedimentation yields and cool, wet winters: test of last glacial paleoclimate in the northern Mediterranean. Geology, 28(11):999-1002.

Cornet, F.H., Doan, M.L., Moretti, I., Borm, G., 2004. Drilling through the active Aigion Fault: the AIG10 well observatory. Comptes Rendus Geoscience, 336 (4-5):395-406.

Croudace, I.W., Rindby, A., Rothwell, R.G., 2006. ITRAX: description and evaluation of a new multi-function X-ray core scanner. Geological Society of London, Special Publication, 267:51-63. doi.org/10.1144/GSL.SP.2006.267.01.04.

Crouzet, C., Sabatier, P., Whilhelm, B., Demory, F., Beck, C., 2017. Magnetic characterization of instantaneous deposits: examples from alpine lakes. Abstract $33^{\text {th }}$ International Meeting of Sedimentology, I.A.S. / A.S.F., p. 209.

De Gelder, G., Fernández-Blanco, D., Melnick, D., Duclaux, G., Bell, R. E., Jara-Muñoz, J., Armijo, R., \& Lacassin, R. (2019). Lithospheric flexure and rheology determined by climate cycle markers in the Corinth Rift. Scientific Reports, 9(1), 4260.

Ferentinos, G., Papatheodorou, G., and Collins, M., 1988. Sediment Transport processes on an active submarine fault escarpment: Gulf of Corinth, Greece. Marine Geology, $83: 43-61$.

Fernández-Blanco, D., de Gelder, G., Lacassin, R., \& Armijo, R. (2019a). Geometry of flexural uplift by continental rifting in Corinth, Greece. Tectonics. https://doi.org/10.1029/2019TC005685

Fernández-Blanco, D., de Gelder, G., Lacassin, R., \& Armijo, R. (2019b). A new crustal fault formed the modern Corinth Rift. Earth Science Reviews, Vol. 199, 102919 
Ford, M., Rohais, S., Williams, E.A., Bourlange, S., Jousselin, D., Backert, N., Malartre, F., 2013. Tectono-sedimentary evolution of the western Corinth Rift (Central Greece). Basin Research, 25(1):3-25.

Galanopoulos, A., Delimbasis, N.D., Comninakis, P.E., 1964. A tsunami generated by a slide without a seismic shock. Geological Chronicles of Greece, 16:93-110.

Gawthorpe, R., Leeder, M., Kranis, H., Skourtsos, E., Andrews, J., Henstra, G., Mack, G., Muravchik, M., Turner, J., \& Stamatakis, M. (2017). Tectono-sedimentary evolution of the Plio-Pleistocene Corinth rift, Greece. Basin Research. http://onlinelibrary.wiley.com/doi/10.1111/bre.12260/full

Gladstone, C., \& Sparks, R. S. J. (2002). The significance of grain-size breaks in turbidites and pyroclastic density current deposits. Journal of Sedimentary Research, 72(1), $182-191$.

Goldfinger, C., Morey, A. E., Nelson, C. H., Gutierez-Pastor, J., Johnson, J. E., Karabanov, E., Eriksson, A., and shipboard scientific party, 2007. Rupture lengths and temporal history of significant earthquakes on the offshore and north coast segments of the Northern San Andreas Fault based on turbidite stratigraphy. Earth and Planetary Science Letters, 254:9-27.

Gràcia, E., Vizcaino, A., Escutia, C., Asioli, A., Rodés, Á., Pallàs, R., Garcia-Orellana, J., Lebreiro, S., Goldfinger, C., 2010. Holocene earthquake record offshore Portugal (SW Iberia): testing turbidite paleoseismology in a slow-convergence margin. Quaternary Science Review, 29:1156-1172. doi.org/10.1016/j.quascirev.2010.01.010.

Hage, S., Cartigny, M. J. B., Sumner, E. J., Clare, M. A., Hughes Clarke, J. E., Talling, P. J., Lintern, D. G., Simmons, S. M., Silva Jacinto, R., Vellinga, A. J., Allin, J. R., Azpiroz-Zabala, M., Gales, J. A., Hizzett, J. L., Hunt, J. E., Mozzato, A., Parsons, D. R., Pope, E. L., Stacey, C. D., ... Watts, C. (2019). Direct Monitoring Reveals Initiation of Turbidity Currents From Extremely Dilute River Plumes. Geophysical Research Letters, 46(20), 11310-11320.

Hizzett, J. L., Hughes Clarke, J. E., Sumner, E. J., Cartigny, M. J. B., Talling, P. J., \& Clare, M. A. (2018). Which triggers produce the most erosive, frequent, and longest runout turbidity currents on deltas? Geophysical Research Letters, 45(2), 855-863.

Jelinek, V., 1981. Characterization of the magnetic fabric of rocks. Tectonophysics, 79:63-67. Jolivet, L., Labrousse, L., Agard, P., Lacombe, O., Bailly, V., Lecomte, E., Mouthereau, 
F.,Mehl, C., 2010. Rifting and shallow-dipping detachments, clues from the Corinth Rift and the Aegean. Tectonophysics, 483:287-304.

doi.org/10.1016/j.tecto.2009.11.001.

Kane, I. A., Kneller, B. C., Dykstra, M., Kassem, A., \& McCaffrey, W. D. (2007). Anatomy of a submarine channel-levee: An example from Upper Cretaceous slope sediments, Rosario Formation, Baja California, Mexico. Marine and Petroleum Geology, 24(6), $540-563$.

Kastens, K., Cita, M.B., 1981. Tsunami-induced sediment transport in the abyssal Mediterrranean Sea. Geological Society of America Bulletin, 92:845-857.

Kneller, B. C., \& McCaffrey, W. D. (2003). The Interpretation of Vertical Sequences in Turbidite Beds: The Influence of Longitudinal Flow Structure. Journal of Sedimentary Research, 73(5), 706-713.

Konfirst, M. A., Kuhn, G., Monien, D., \& Scherer, R. P. (2011). Correlation of Early Pliocene diatomite to low amplitude Milankovitch cycles in the ANDRILL AND-1B drill core. Marine Micropaleontology, 80(3), 114-124.

Koukouvelas, I.K., Katsonopoulou, D., Soter, S., Xypolias, P., 2005. Slip rates on the Helike Fault, Gulf of Corinth, Greece: new evidence from geoarchaeology. Terra Nova, 17:158-164. doi.org/10.1111/j.1365-3121.2005.00603.x.

Leeder, M.R., Portman, C., Andrews, J.E., Collier, R.E.L., Finch, E., Gawthorpe, R.L., McNeill, L.C., Pérez-Arlucea, M., Rowe, P., 2005. Normal faulting and crustal deformation, Alkyonides Gulf and Perachora peninsula, eastern Gulf of Corinth rift, Greece. Journal of the Geological Society of London, 162:549-561.

Lemeille, F., Chatoupis, F., Foumelis, M., Rettenmaier, D., Unkel, I., Micarelli, L., Moretti, I., Bourdillon, C., Guernet, C., Müller, C., 2004. Recent syn-rift deposits in the hangingwall of the Aigion Fault (Gulf of Corinth, Greece). Comptes Rendus Geoscience, 336 :425-434, dx.doi.org/10.1016/j.crte.2003.11.009.

Lorenzoni, L., Benitez-Nelson, C.R., Thunel, R.C., David Hollander, D., Varela, R., Astor, Y., Audemard, F.A., Muller-Karger, F.E., 2012. Potential role of event-driven sediment transport on sediment accumulation in the Cariaco Basin, Venezuela. Marine Geology, 307:105-110.

Lowe, D. R. (1982). Sediment gravity flows; II, Depositional models with special reference to the deposits of high-density turbidity currents. Journal of Sedimentary Research, 52(1), 279-297.

Lykousis, V., Sakellariou, D., Moretti, I., Kaberi, H., 2007. Late Quaternary basin evolution 
of the Gulf of Corinth: sequence stratigraphy, sedimentation, fault-slip and subsidence rates. Tectonophysics, 440 :29-51, doi.org/10.1016/j.tecto.2006.11.007.

Lykousis, V., Roussakis, G., Sakellariou, D., 2009. Slope failures and stability analysis of shallow water prodeltas in the active margins of Western Greece, northeastern Mediterranean Sea. International Journal of Earth Sciences, 98:80-822. doi.org/10.1007/s00531-008-0329-9.

Marco, S., Agnon, A., 1995. Prehistoric earthquake deformations near Masada, Dead Sea Graben. Geology, 23(8):695-698.

Maffione, M., \& Morris, A. (2017). The onset of fabric development in deep marine sediments. Earth and Planetary Science Letters, 474, 32-39.

McCalpin, J., 2009. Paleoseismology. $2^{\text {nd }}$ Edition. International Geophysics Series, Elsevier, 95:1-613.

McHugh, C., Kanamatsu, T., Seeber, L., Bopp, R., Cormier, M.-H., and Usami, K., 2016. Remobilization of surficial slope sediment triggered by the A.D. $2011 \mathrm{Mw} 9$ TohokuOki earthquake and tsunami along the Japan Trench. Geology, 44(70):391-394. doi:10.1130/G37650.1

McHugh, C., Braudy, N., Cağatay, N., Sorlien, C., Cormier, M.-H., Seeber, L., Henry, P., 2014. Seafloor fault ruptures along the north anatolia fault in the marmara Sea, Turkey: link with the adjacent basin turbidite record. Marine Geology, 353, 65-83. McHugh, C., Seeber, L., Braudy, N., Cormier, M.-H., Davis, M.B., Diebold, J.B., Dieudonne, N., Douilly, R., Gulik, S.P.S., Hornbach, M.J., Johnson III, H.E., Ryan Miskin, K., Sorlien, C., Steckler, M., Symithe, S.J., Templeton, J., 2011. Offshore sedimentary effects of the 12 January 2010 Haiti earthquake. Geology, 39 (8):723726.

McHugh, C., Seeber, L., Cormier, M., Dutton, J., Cagatay, N., Polonia, A., Ryan,W., Gorur, N., 2006. Submarine earthquake geology along the North Anatolia Fault in the Marmara Sea, Turkey: a model for transform basin sedimentation. Earth and Planetary Science Letter, 248:661-684. doi.org/10.1016/j.eps1.2006.05.038.

McHugh, C., Seeber, L., Rasbury, T., Strasser, M., Arata Kioka, A., Kanamatsu, T., Ikehara, K., Usami, K., 2020. Isotopic and sedimentary signature of megathrust ruptures along the Japan subduction margin. Marine Geology, 428: 1-20, doi.org/10.1016/j.margeo.2020.106283

McNeill, L.C., Cotterill, C.J., Bull, J.M., Henstock, T.J., Bell, R., Stefatos, A., 2007. 
Geometry and slip rate of the Aigion fault, a young normal fault system in the western Gulf of Corinth. Geology, 35:355. doi.org/10.1130/G23281A.1.

McNeill, L.C., $\quad$ ton, D.J., Carter, G.D.O., and the Expedition 381 Participants, 2019a. Expedition 381 methods. Proceedings of the International Ocean Discovery Program, Volume 381publications, p.1-35, doi.org/10.14379/iodp.proc.381.102.

McNeill, L.C., Shillington, D. J., Carter, G. D. O., Everest, J. D., Gawthorpe, R. L., Miller, C., Phillips, M. P., Collier, R. E. L., Cvetkoska, A., De Gelder, G., Diz, P., Doan, M.L., Ford, M., Geraga, M., Gillespie, J., Hemelsdaël, R., Herrero-Bervera, E., Ismaiel, M., Janikian, L., ... Green, S., 2019b. High-resolution record reveals climate-driven environmental and sedimentary changes in an active rift. Scientific Reports, 9(1), 6519.

Migeon, S., Weber, O., Faugères, J.-C., Saint-Paul, J., 1998. A new X-ray imaging system for core analysis. Geomarine Letters, 18:251-255.

Moretti, I., Lykousis, V., Sakellariou, D., Reynaud, J.-Y., Benziane, B., and Prinzhoffer, A., 2004. Sedimentation and subsidence rate in the Gulf of Corinth: what we learn from the Marion Dufresne's long piston coring, Comptes Rendus Geoscience, 336:291-299.

Mulder, T., Zaragosi, S., Razin, P., Grelaud, C., Lanfumeya, V., Bavoi, F., 2009. A new conceptual model for the deposition process of homogenite: Application to a cretaceous megaturbidite of the western Pyrenees (Basque region, SW France). Sedimentary Geology, 222:263-273

Mutti, E., Ricci Lucchi, F., 1972. Turbidites of the northern Apennines: introduction to facies analysis (English translation by T.H. Nilsen, 1978). International Geological Review, 20:125-166.

Papadopoulos, G.A., 2003. Tsunami hazas, rd in the Eastern Mediterranean: strong Earthquakes and tsunamis in the Corinth Gulf, Central Greece. Natural Hazards, 29:437-464.

Papatheodorou, G., Ferentinos, G., 1997. Submarine and coastal sediment failure triggered by the 1995, M=6.1 R Aegion earthquake, Gulf of Corinth, Greece. Marine Geology, 137:287-304.

Passega, R., 1964. Grain size representation by CM Pattern as a Geological Tool. S.E.P.M., Journal of Sedimentary Research, 34(4):830-847.

Pechlivanidou, S., Cowie, P. A., Duclaux, G., Nixon, C. W., Gawthorpe, R. L., \& Salles, T. (2019). Tipping the balance: Shifts in sediment production in an active rift setting. Geology, 47(3), 259-262. 
Perissoratis, C., Piper, D.J.W., Lykousis, V., 2000. Alternating marine and lacustrine sedimentation during late Quaternary in the Gulf of Corinth rift basin, central Greece. Marine Geology, 167:391-411.

Pérouse, E., Chamot-Rooke, N., Rabaute, A., Briole, P., Jouanne, F., Georgiev, I., Dimitrov, D., 2012. Bridging onshore and offshore present-day kinematics of central and eastern Mediterranean: implications for crustal dynamics and mantle flow. Geochemistry, Geophysics, Geosystems, (13)9. doi:10.1029/2012GC004289.

Piper, D.J.W., Kontopoulos, N., Anagnostou, C., Chronis, G., Panagos, A.G., 1990. Modern fan deltas in the western Gulf of Corinth, Greece. Geo-Marine Letters, 10:5-12.

Polonia, A., Panieri, G., Gasperini, L., Gasparotto, A., Bellucci, L.G., and L. Torelli, L., 2013. Turbidite paleoseismology in the Calabrian Arc Subduction Complex (Ionian Sea). Geochemistry, Geophysics, Geosystems, 14:112-140, doi:10.1029/2012GC004402.

Polonia, A., Nelson, C.H., Romano, S., Vaiani, S.C., Colizza, E., Gasparotto, G., Gasperini, L., 2017. A depositional model for seismo-turbidites in confined basins based on Ionian Sea deposits. Marine Geology, 384:177-198.

Rigo, A., Lyon-Caen, H., Armijo, R., Deschamp, A., Hatzfeld, D., Makropoulos, K., Papadimitriou, P., Kassaras, I., 1996. A microseismic study in the western part of the Gulf of Corinth (Greece): implications for large-scale normal faulting mechanisms. Geophysical Journal International, 126 :663-688.

Pantosti, D., De Martini, P.M., Koukouvelas, I., Stamatopoulos, L., Palyvos, N., Pucci, S., Lemeille, F., S., P., 2004. Palaeoseismological investigations of the Aigion Fault (Gulf of Corinth, Greece). Comptes Rendus Geoscience. 336:335-342. doi.org/10.1016/ j.crte.2003.12.005.

Pickering, K. T., \& Hiscott, R. N. (1985). Contained (reflected) turbidity currents from the Middle Ordovician Cloridorme Formation, Quebec, Canada: an alternative to the antidune hypothesis. Sedimentology, 32(3), 373-394.

Ratzov, G., Cattaneo, A., Babonneau, N., Deverchère, J., Yelles, K., Bracene, R., Courboulex, F., 2015. Holocene turbidites record earthquake supercycles at a slow-rate plate boundary. Geology, 43:331-334. doi.org/10.1130/G36170.1

Reimer, P.J., Bard, E., Bayliss, A., Beck, J.W., Blackwell, P.G., Ramsey, C.B., Buck, C.E., Cheng, H., Edwards, R.L., Friedrich, M., 2013. IntCal13 and Marine13 radiocarbon age calibration curves 0-50,000 years cal BP. Radiocarbon 55, 1869e1887.

Reimer, P., McCormac, F., 2002. Marine radiocarbon reservoir corrections for the 
Mediterranean and Aegean seas. Radiocarbon 44, 159e166.

Rodriguez-Pascua, M.A., Calvo, J.P., De Vicente, G., Gòmez-Gras, D., 2002. Soft-sediment deformation structures interpreted as seismites in lacustrine sediments of the Prebetic Zone, SE Spain, and their potential use as indicators of earthquake magnitudes during the Late Miocene. Sedimentary Geology, 135(1/4):117-135.

Rothwell, R. G., Hoogakker, B., Thomson, J., Croudace, I. W., \& Frenz, M. (2006). Turbidite emplacement on the southern Balearic Abyssal Plain (western Mediterranean Sea) during Marine Isotope Stages 1--3: an application of ITRAX XRF scanning of sediment cores to lithostratigraphic analysis. Geological Society, London, Special Publications, 267(1), 79-98.

Rothwell, R. G., Croudace, I. W. (2015). Twenty Years of XRF Core Scanning Marine Sediments: What Do Geochemical Proxies Tell Us? In I. W. Croudace \& R. G. Rothwell (Eds.), Micro-XRF Studies of Sediment Cores: Applications of a nondestructive tool for the environmental sciences (pp. 25-102). Springer Netherlands.

San Pedro, L., Babonneau, N., Gutscher, M.A., Cattaneo, A., 2017. Origin and chronology of the Augias deposit in the Ionian Sea (Central Mediterranean Sea), based on new regional sedimentological data. Marine Geology, 384:199-213.

Shanmugan, G., 1997. The Bouma sequence and the turbidite mind set. Earth Science Review, 42:201-229.

Siegenthaler, C., Finger, W., Kelts, K., and Wang, S., 1987. Earthquake and seiche deposits in Lake Lucerne, Switzerland. Eclogae geologiae Helvetiae, 80:241-260.

Sinclair, H. D., \& Cowie, P. A. (2003). Basin-floor topography and the scaling of turbidites. The Journal of Geology, 111(3), 277-299.

Stanley, D.J., 1981. Unifites: structureless muds of gravity-flow origin in Mediterranean basins. Geo-Marine Letters, 1:77-83.

Stefatos, A., Charalambakis, M., Papatheodorou, G., Ferentinos, G., 2006. Tsunamigenic sources in an active European half-graben (Gulf of Corinth, Central Greece). Marine Geology, 232:35-47. doi.org/10.1016/j.margeo.2006.06.004

Stevenson, C. J., Talling, P. J., Masson, D. G., Sumner, E. J., Frenz, M., \& Wynn, R. B. (2014). The spatial and temporal distribution of grain-size breaks in turbidites. Sedimentology, 61(4), 1120-1156.

Stow, D.A.V. (Ed.), 1992. Deep-water turbidite systems. International Associations of Sedimentologists, Reprint Series 3, Blackwell Sc. Publ., 473 pp..

Stow, D.A.V., Wetzel, A., 1990. Hemiturbidite: a new type of deepwater sediment. 
Proceeding of the Ocean Drilling Program 105B, 25-34.

Strasser, M., Hilbe, M., Anselmetti, F.S., 2011. Mapping basin-wide subaquatic slope failure susceptibility as a tool to assess regional seismic and tsunami hazards. Marine Geophysical Research, 32:331-347. doi.org/10.1007/s11001-010-9100-2.

Sturm, M., Siegenthaler, C., and Pickrill, R.A, 1995. Turbidites and 'homogenites". A conceptual model of flood and slide deposits. Publication of the International Association of Sedimentologists, 16th Regional Meeting, Paris, 22:140.

Talling, P. J., Masson, D. G., Sumner, E. J., Malgesini, G., 2012. Subaqueous sediment density flows: Depositional processes and deposit types. Sedimentology, 59:19372003, doi: 10.1111/j.1365-3091.2012.01353.x

Taylor, B., Weiss, J.R., Goodliffe, A.M., Sachpazi, M., Laigle, M., Hirn, A., 2011. The structures, stratigraphy and evolution of the Gulf of Corinth rift, Greece. Geophysical Journal International, 185:1189-1219. doi.org/10.1111/j.1365-246X.2011.05014.x.

Thomson, J., Croudace, I., Rothwell, R., 2006. A geochemical application of the ITRAX scanner to a sediment core containing eastern Mediterranean sapropel units. Geological Society of London, Spec. Publ. 267(1):65-77.

Thunell, R., Tappa, E., Valera, R., Llano, M., Astor, Y., Muller-Karger, F., Bohrer, R., 1999. Increased marine sediment suspension and fluxes following an earthquake. Nature, 398:233-236.

Vanneste, K., Wils, K., \& Van Daele, M., 2018. Probabilistic evaluation of fault sources based on paleoseismic evidence from mass-transport deposits: The example of Aysén Fjord, Chile. Journal of Geophysical Research: Solid Earth, 123:9842-9865. doi.org/10.1029/2018JB016289

Van Daele, M., Araya-Cornejo, M.C., Pille, T., Vanneste, K., Moernaut, J., Schmidt, S., Kempf, P., Meyer, I., and Cisternas, M., 2019. Distinguishing intraplate from megathrust earthquakes using lacustrine turbidites. Geology, v. 47, p. 127-130, doi.org/10.1130/G45662.1.

Van Daele, M., W. Versteeg, M. Pino, R. Urrutia, and M. De Batist (2013), Widespread deformation of basin-plain sediments in Aysén fjord (Chile) due to impact by earthquake-triggered, onshore-generated mass movements, Marine Geology, 337:6779. doi:10.1016/ j.margeo .2013.01.006.

Van Welden, A., Beck, C., Reyss, J.-L., Bushati, S., Koci, R., Jouanne, F., Mugnier, J.-L., 
2008. The last 500 year of sedimentation in Shkodra Lake (Albania/Montenegro): paleoenvironmental evolution and potential for paleoseismicity studies. Journal of Paleolimnology, 40:619-633.

Watkins, S.E., Whittaker, A.C., Bell, R.E., McNeill, L.C., Gawthorpe, R.L., Brooke, S.A.S., and Casey W. Nixon, C.W., 2019. Are landscapes buffered to high-frequency climate change? A comparison of sediment fluxes and depositional volumes in the Corinth Rift, central Greece, over the past 130 k.y. Geological Society of America Bulletin,131 (3-4): 372-388. https://doi.org/10.1130/B31953.1

Zavala, C., \& Arcuri, M. (2016). Intrabasinal and extrabasinal turbidites: Origin and distinctive characteristics. Sedimentary Geology, 337, 36-54.

Zavala, C., Arcuri, M., Di Meglio, M., Diaz, H. G., \& Contreras, C. (2011). A genetic facies tract for the analysis of sustained hyperpycnal flow deposits. 31-51. 


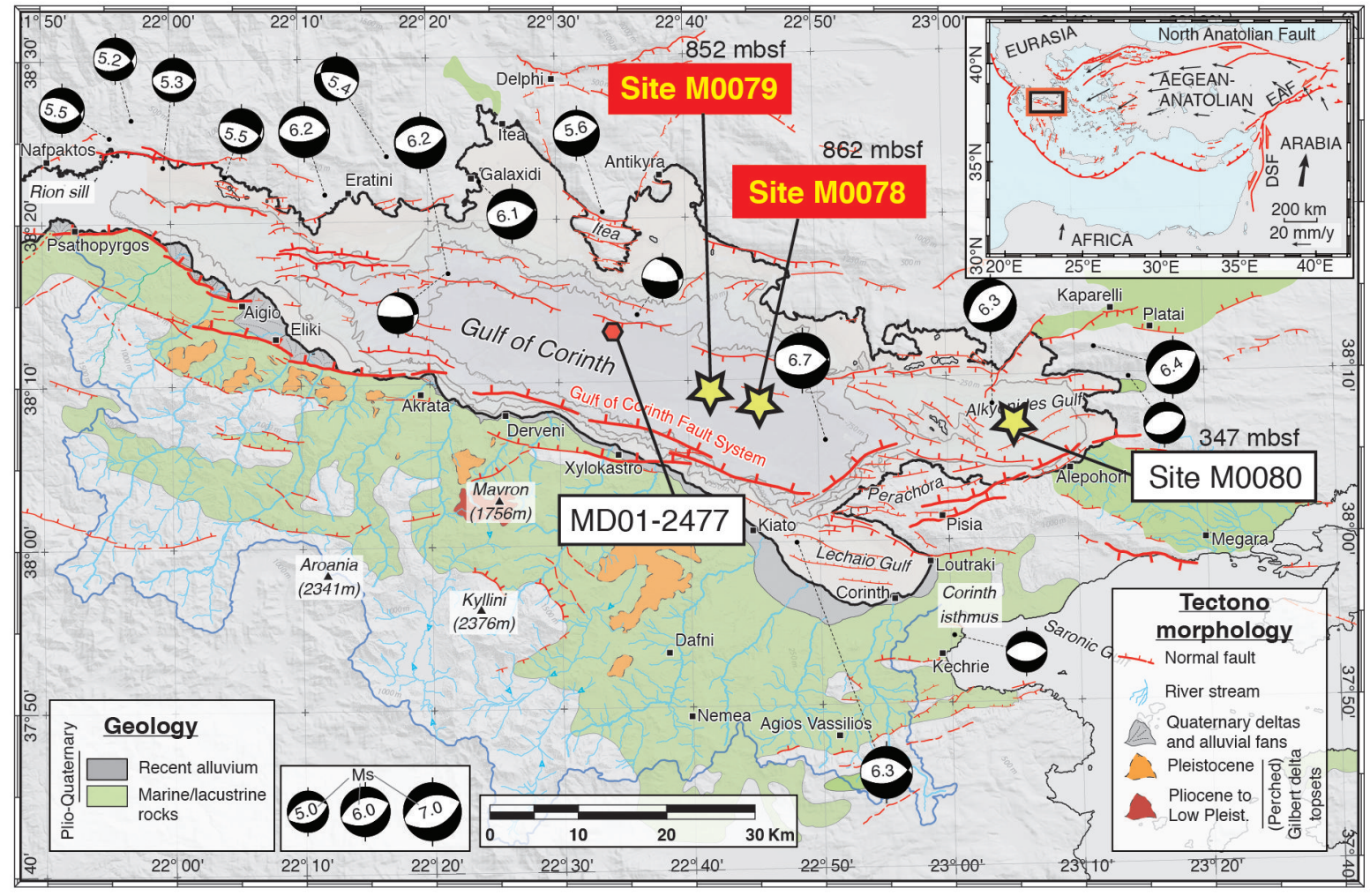

Figure 1 - Location of studied coring sites in the Gulf of Corinth. Stars indicate IODP-381 coring sites, with samples from red sites used in this study. Bathymetry is shown with contours every $250 \mathrm{~m}$, and faults are the major onshore and offshore active faults bounding the Corinth Rift. Fault thickness indicates relative fault importance, and inset shows tectonic setting. After Fernandez-Blanco et al., 2019a and references therein. 


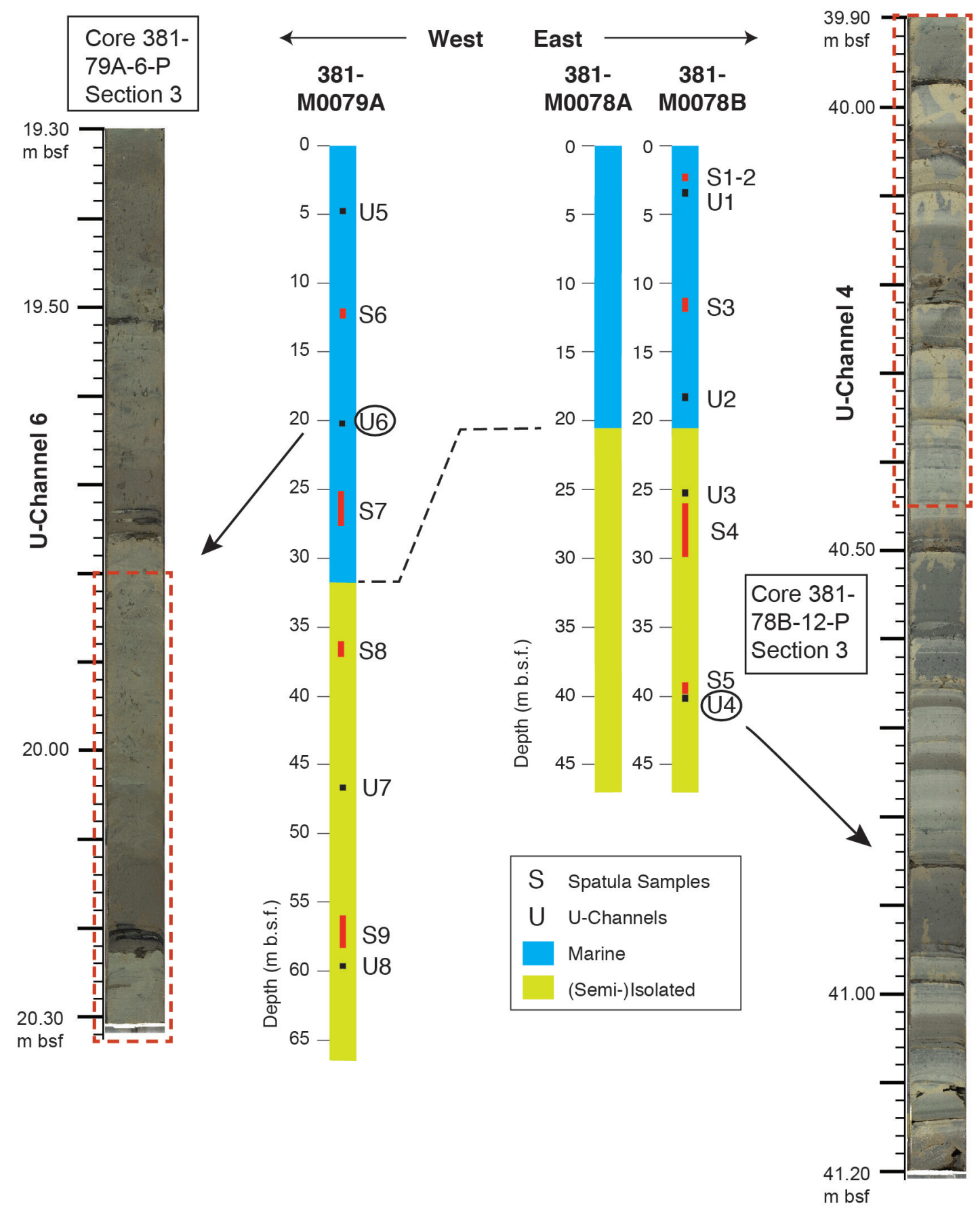

Figure 2 - Location of different sampling along the last $\sim 25$ ky BP interval. View of split core sections concerned by detailed presentation. 


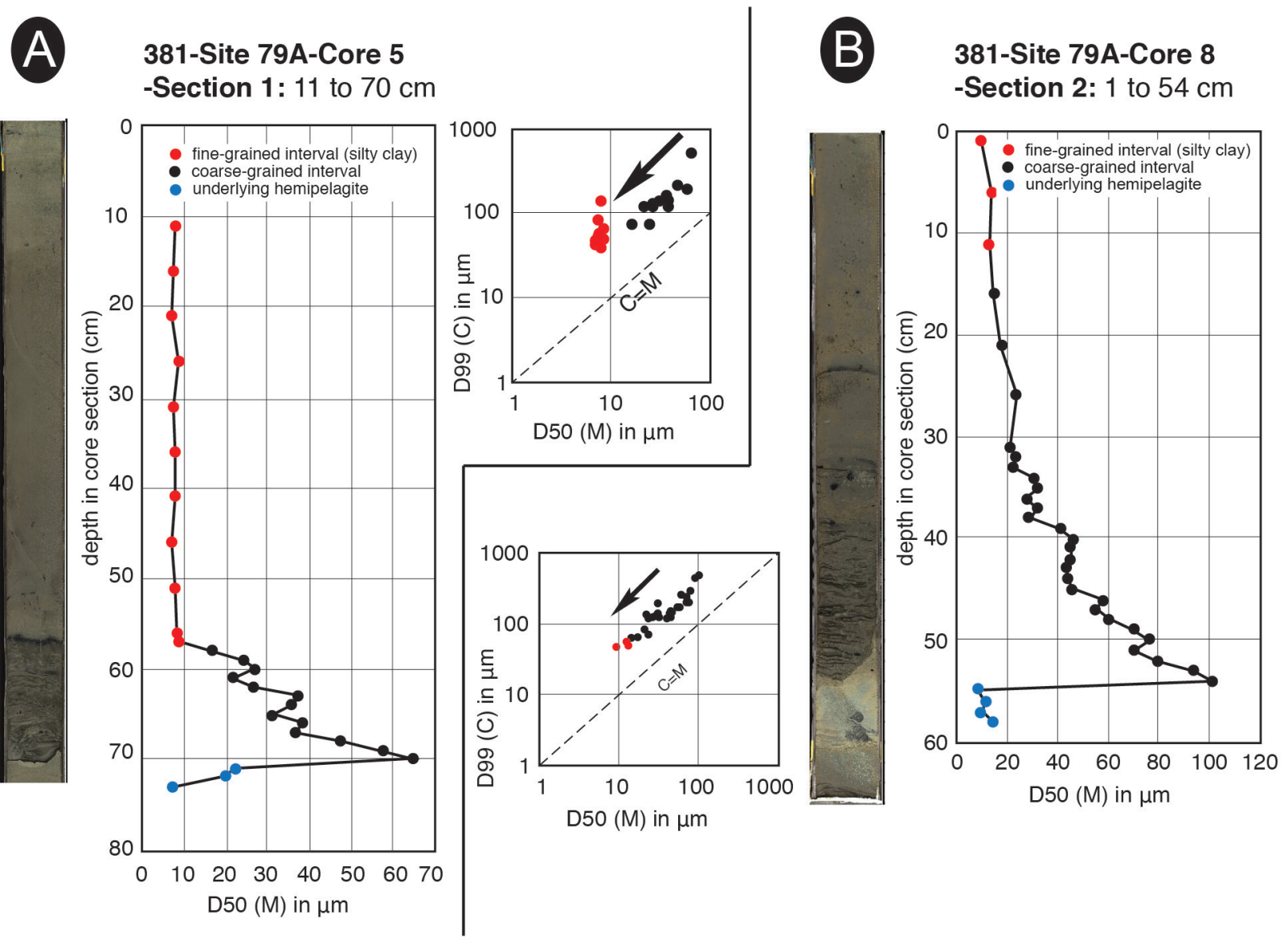

Figure 3 - Selected examples of "classical" turbidite (Tu) and single homogenite+turbidite (HmTus). Base-to-top grain-size evolution is shown with D50 (Median or M), and Passega (1964)'s CM diagram combining the D50 (M) and the D99 (C) in logarithmic coordinates. Location of samples S6 and S7 is shown on Figure 2. 


\section{A}
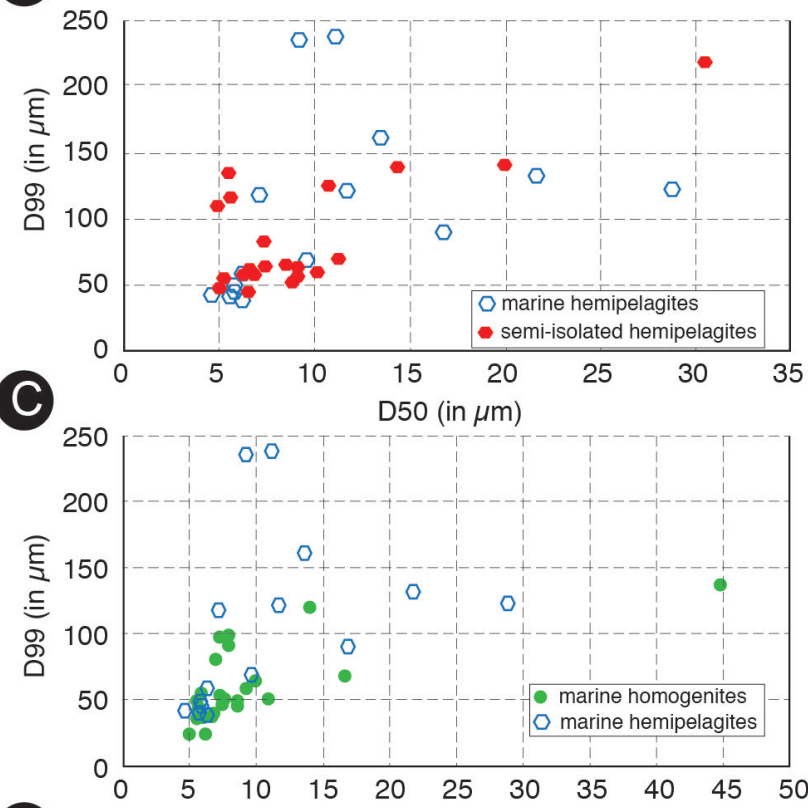

E

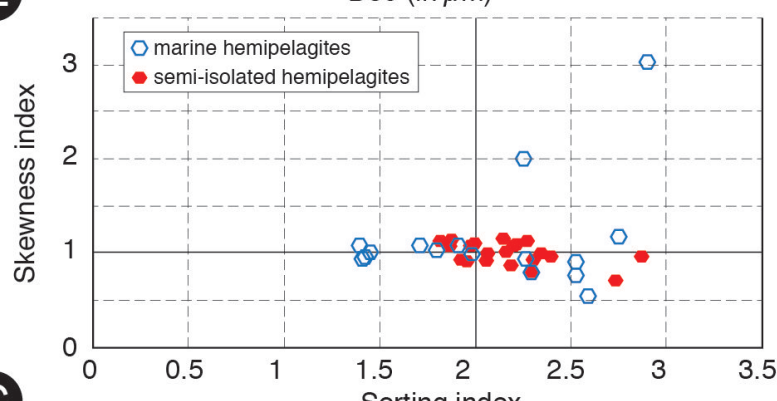

G

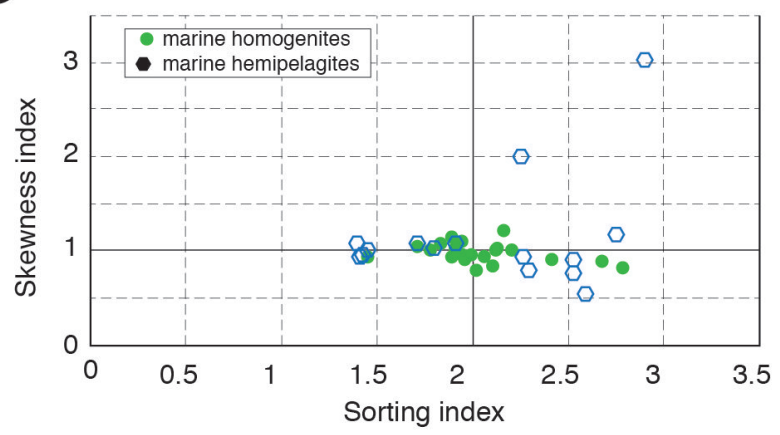

B
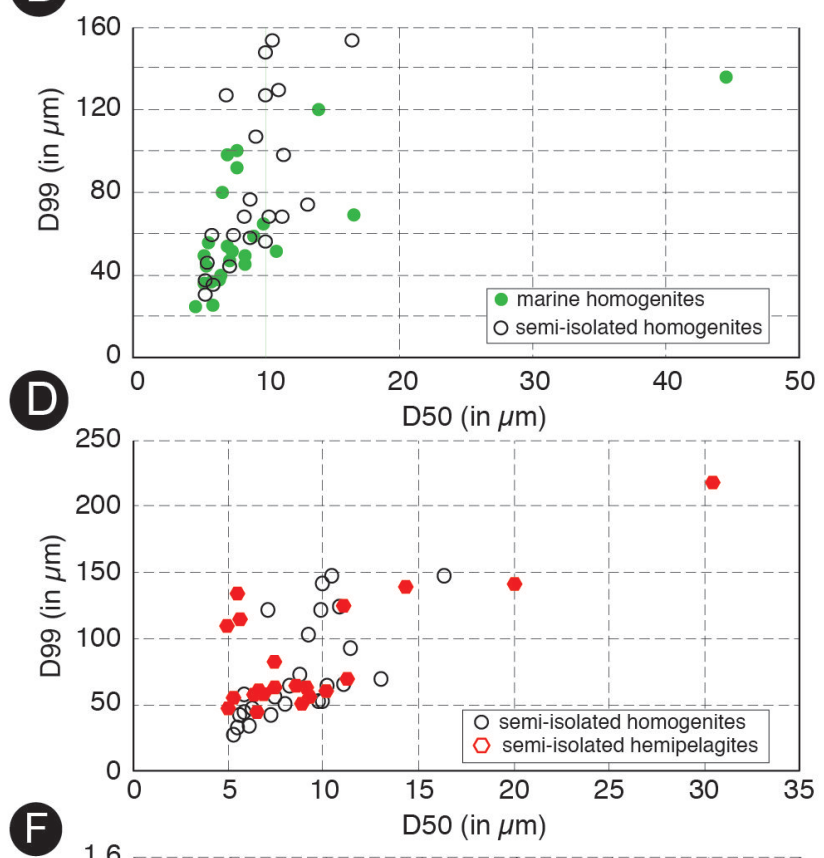

F

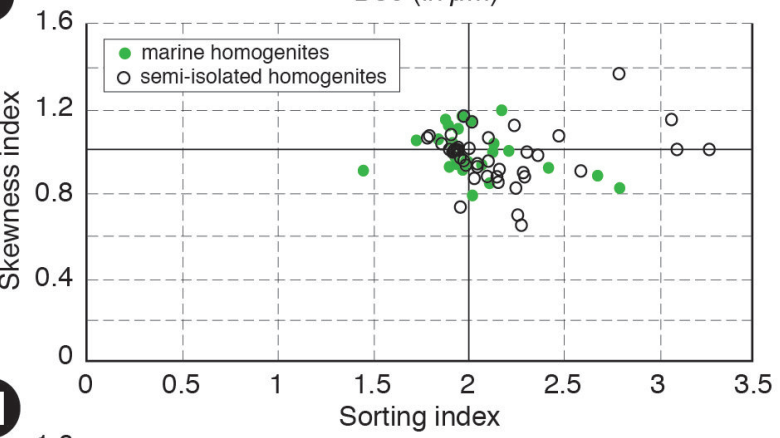

H

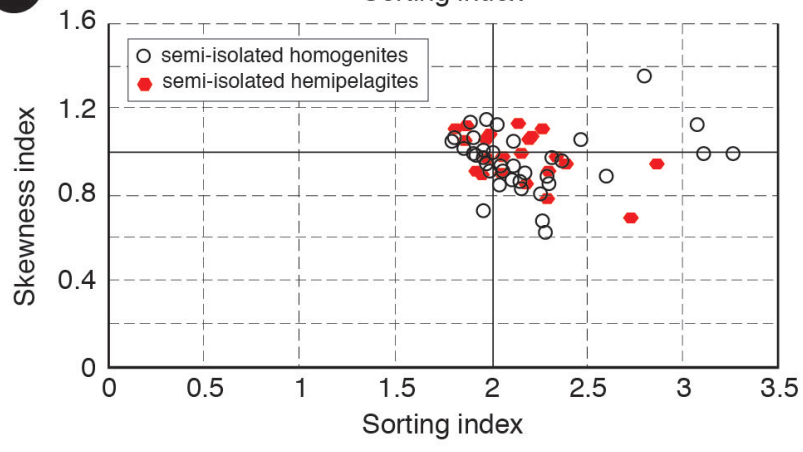

Figure 4.- Binary cross-plots of grain-size parameters of hemipelagites and homogenites in marine and (semi-)isolated (SI) environments. Marine samples from U-channels 2, 5, and 6 ( 15 hemipelagite and 24 homogenite samples), SMI samples from U-channels 3, 4, 7 and 8 (22 hemipelagite and 35 homogenite samples). Diagrams A to D display a general characterization through D50 (Median) and D99 (coarsest particles). Diagrams $\mathrm{E}$ to $\mathrm{F}$ are dedicated to discuss depositional processes through classical Sorting and Skewness indices. Location of U-channels is shown on Figure 2. 

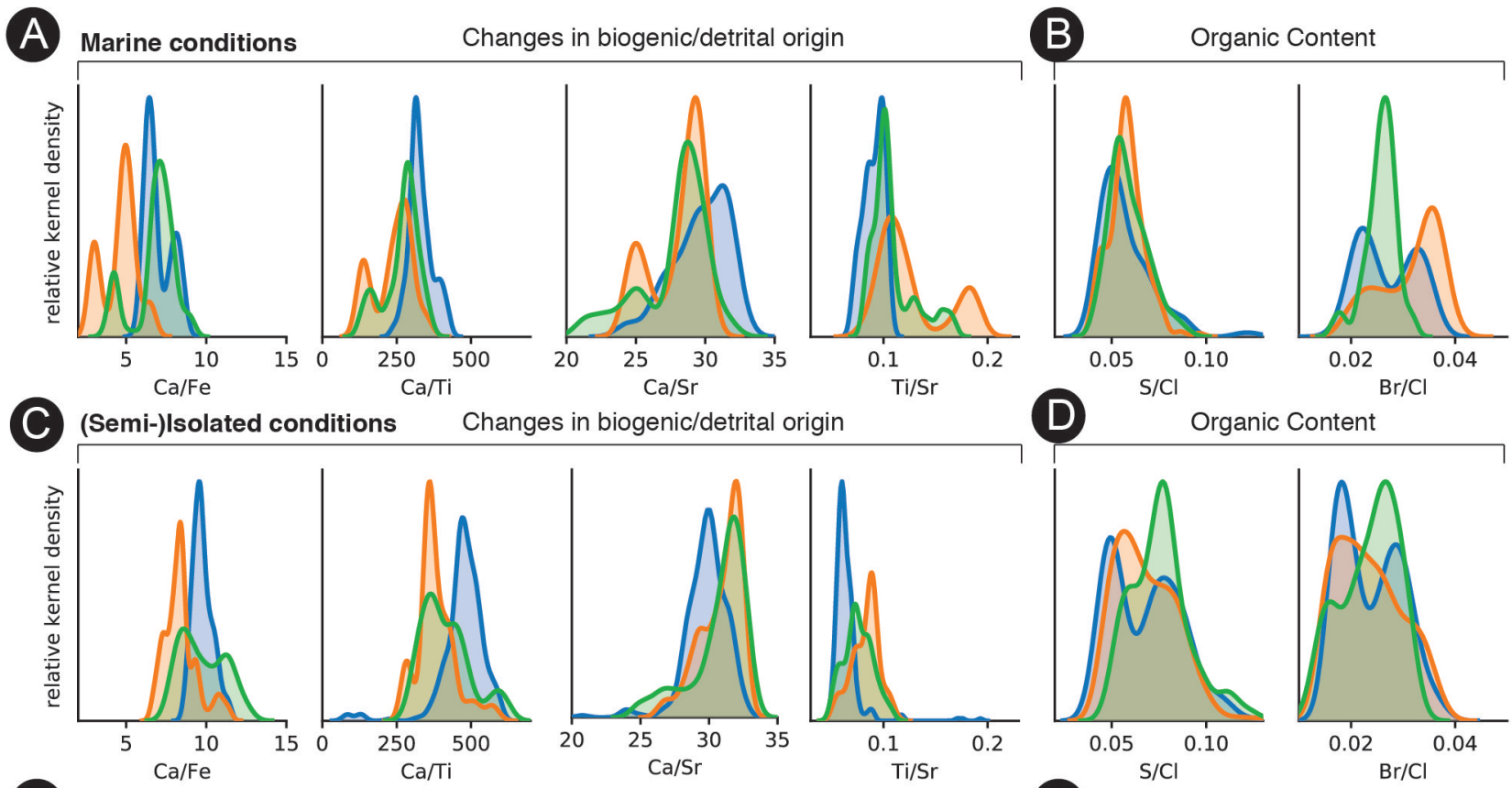

E Marine conditions

Sedimentary Provenance/Grainsize
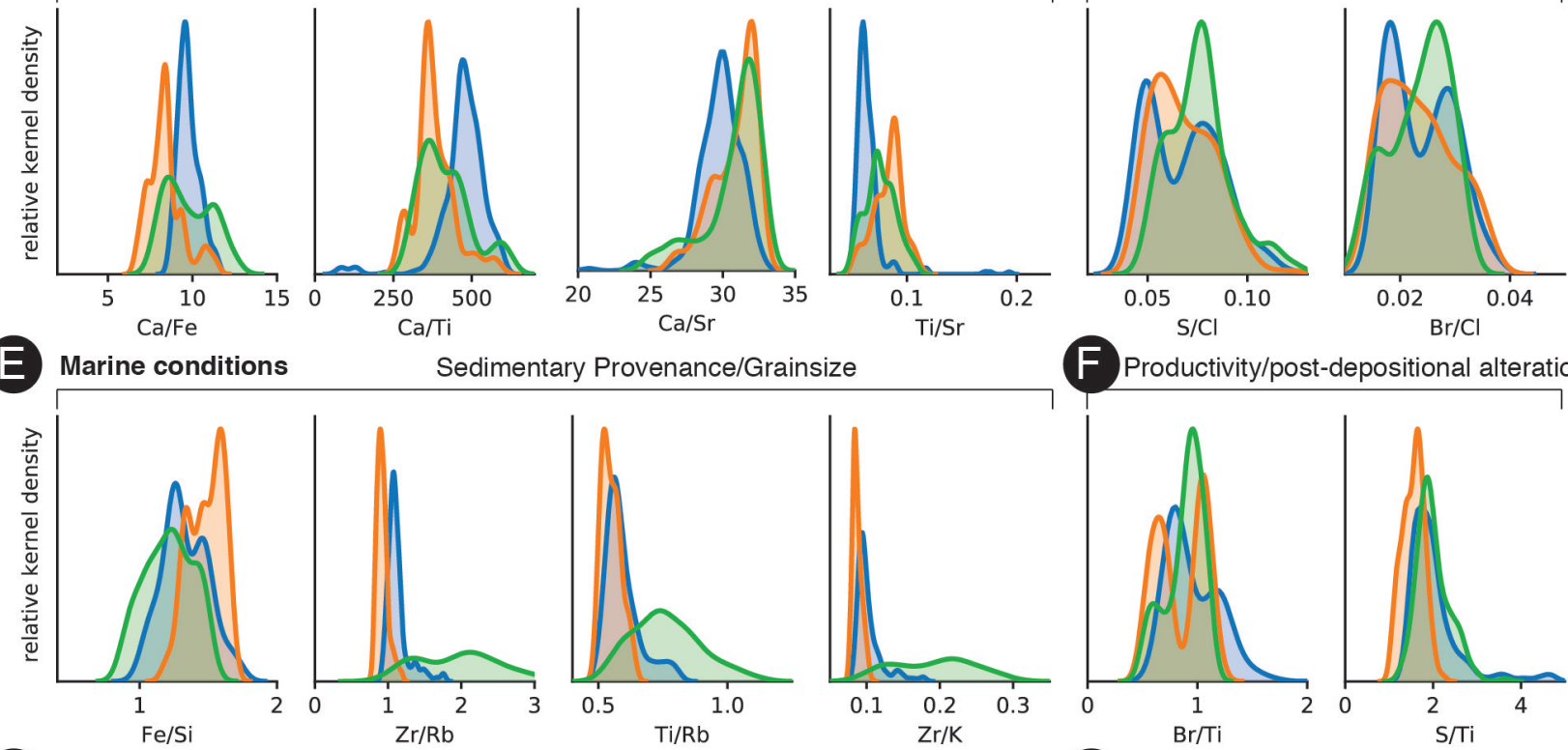

G

(Semi-)lsolated conditions Sedimentary Provenance/Grainsize
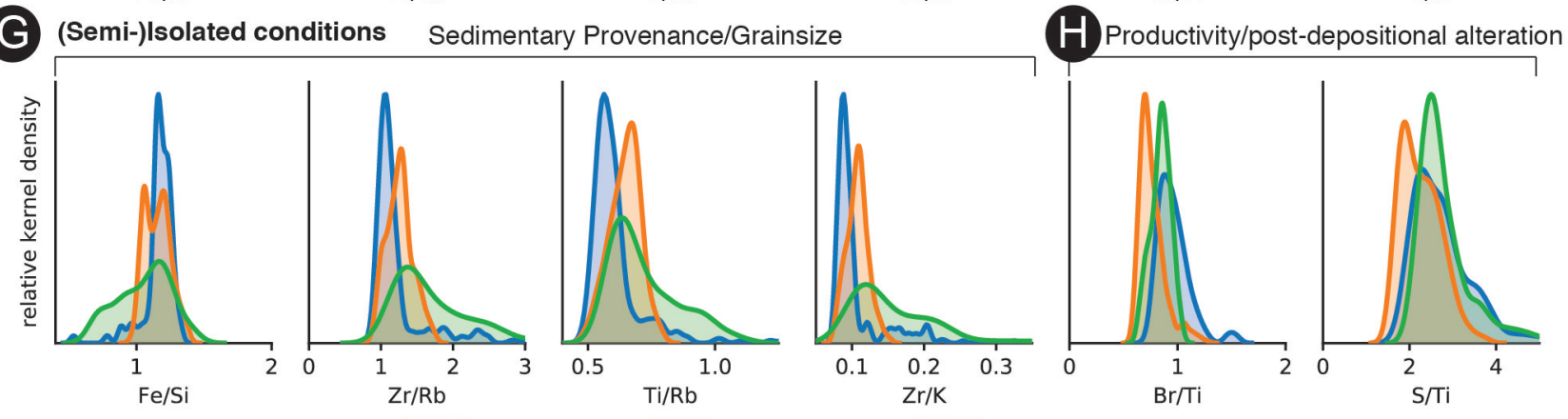

Turbidite

Homogenite

Hemipelagite

Figure 5 - X-Ray Fluorescence (XRF) ratios for marine vs. (semi-)isolated (SMI) conditions. Selection of 12 XRF ratios, distinguishing between Turbidites, Homogenites and Hemipelagites. Measurements come from all ten U-channels; values referred as "turbidites" come from classical turbidites (single Tu) and coarse bases of homogenites+turbidites (Tu term of HmTu). 


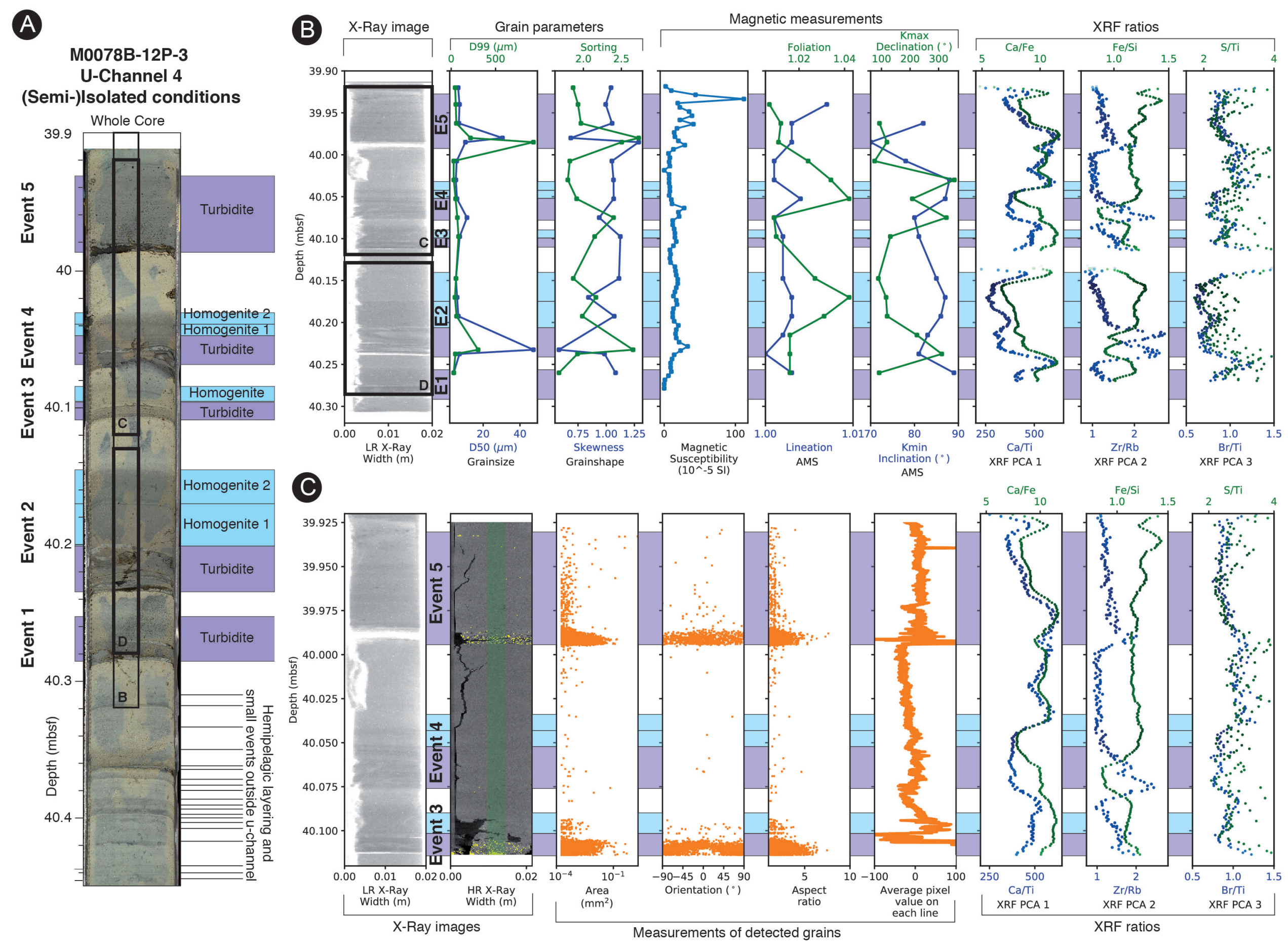




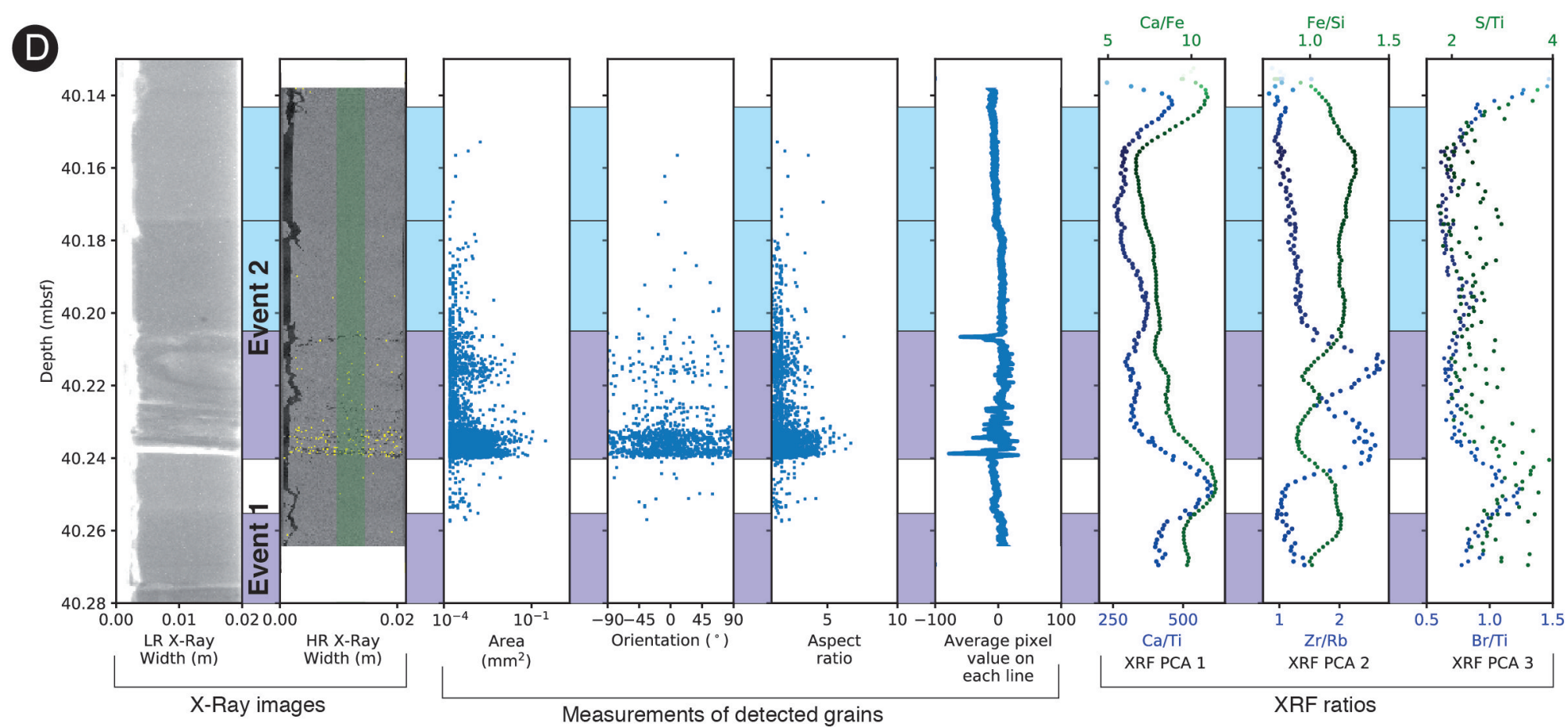

Figure 6.- Overview of U-Channel 4 a) Whole core overview including position of u-channel and different events. b) Low Resolution (LR) X-Ray image and measurements of U-Channel 4 including grainsize, grain shape, magnetic susceptibility, Anisotropy of Magnetic Susceptibility (AMS) and selected X-Ray Fluorescence (XRF) ratios for each of the three strongest Principal Components (see Fig. 5). c) Zoom-in on upper portion of U-Channel 4, including Low Resolution (LR) and High Resolution (HR) X-Ray images and measurements of area, orientation, and aspect of visible grains in HR X-Ray, average pixel value in HR X-Ray, and the same XRF ratios as in b. d) Same as in c, but for the lower portion of U-Channel 4. 
A

M0079A-6P-3

U-Channel 6

Marine Conditions

Whole Core

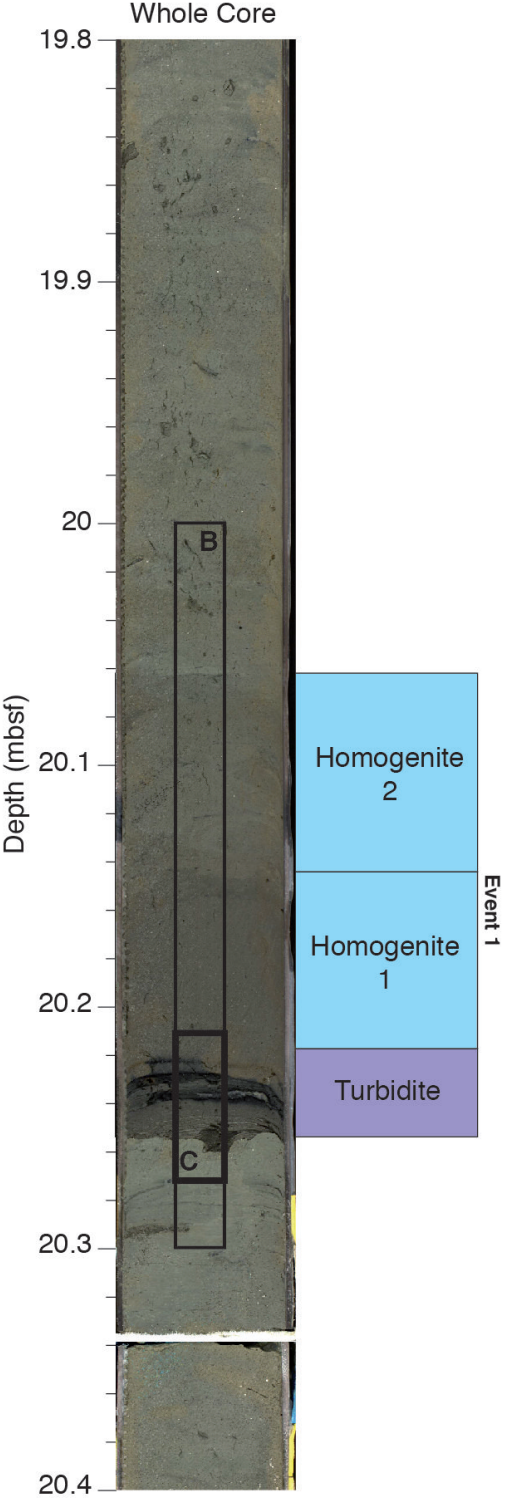

B

X-Ray image

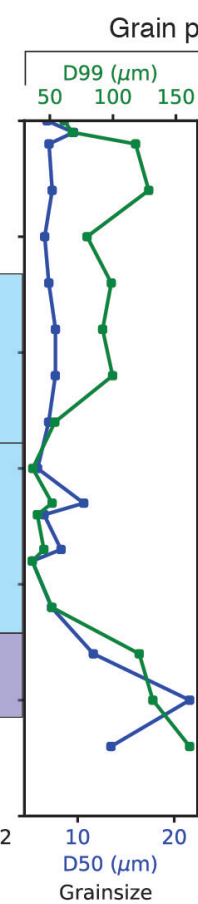

Grain parameters
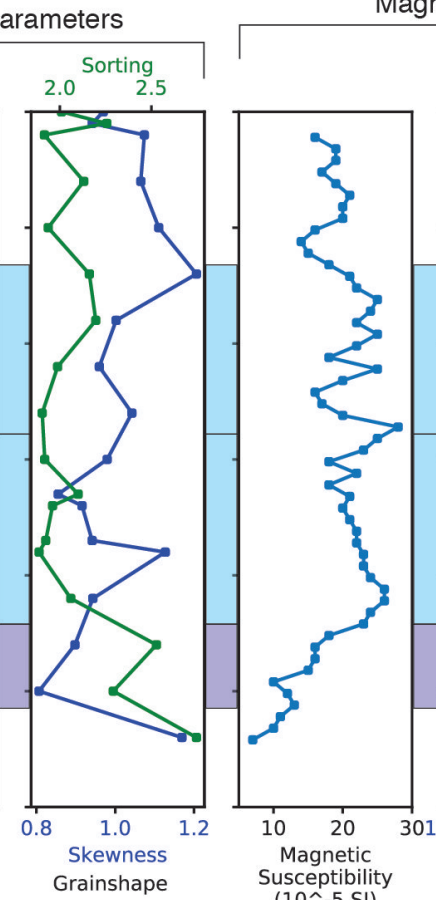

Magnetic measurements
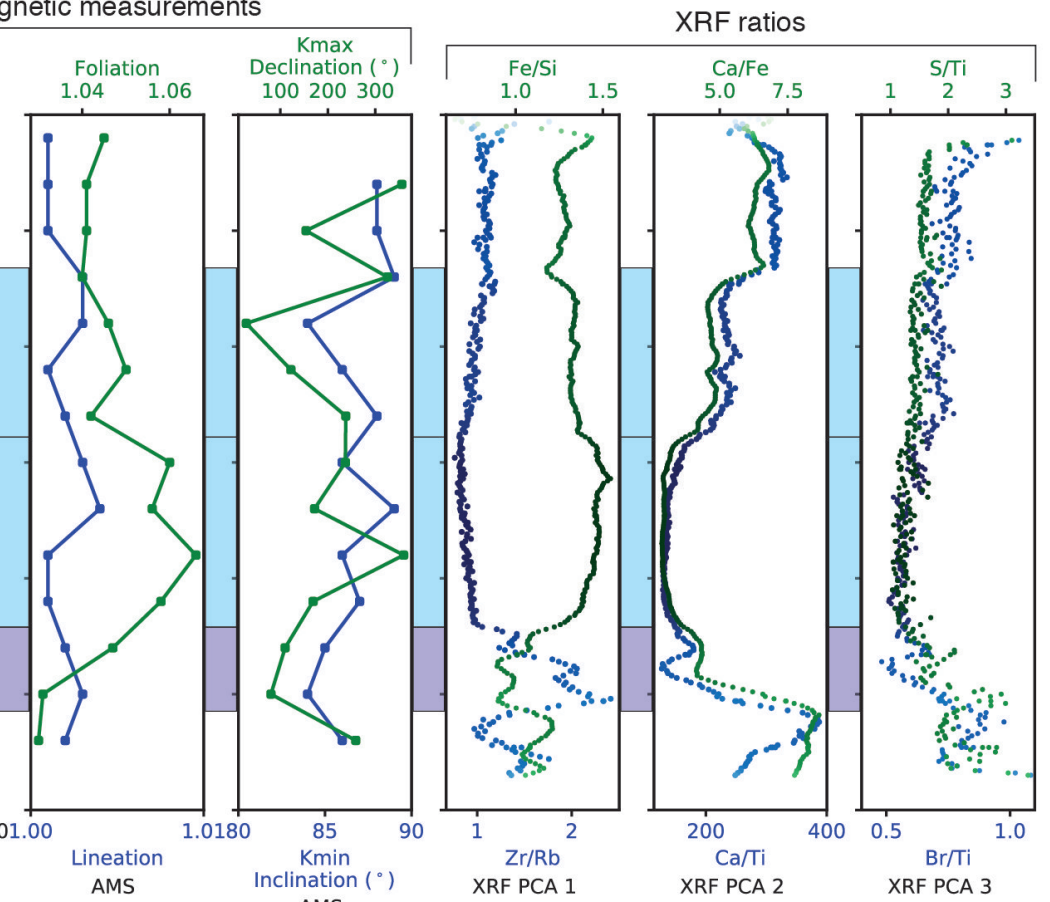

C

XRF PCA 2

XRF PCA 3

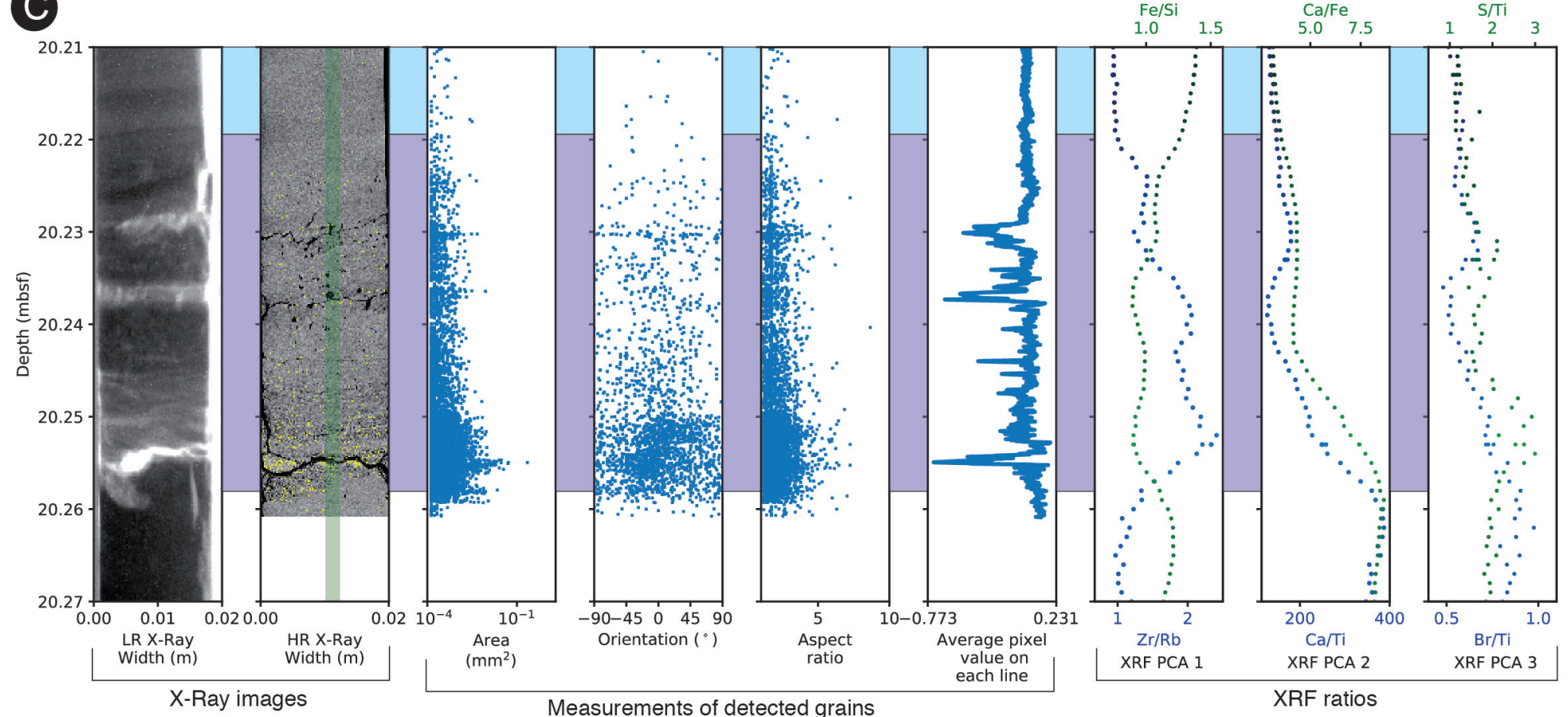

Measurements of detected grains

XRF ratios

Figure 7 - Overview of U-Channel 6. a) Whole core overview including position of U-channel 6 and different events. b) Low Resolution (LR) X-Ray image and measurements of U-Channel 6, including

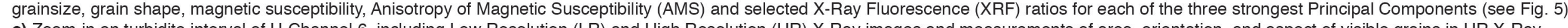
c) Zoom-in on turbidite interval of U-Channel 6, including Low Resolution (LR) and High Resolution (HR) X-Ray images and measurements of area, orientation, and aspect of visible grains in HR X-Ray, average pixel value in HR X-Ray, and the same XRF ratios as in $b$. 
A Microtomography

U-Channel 4

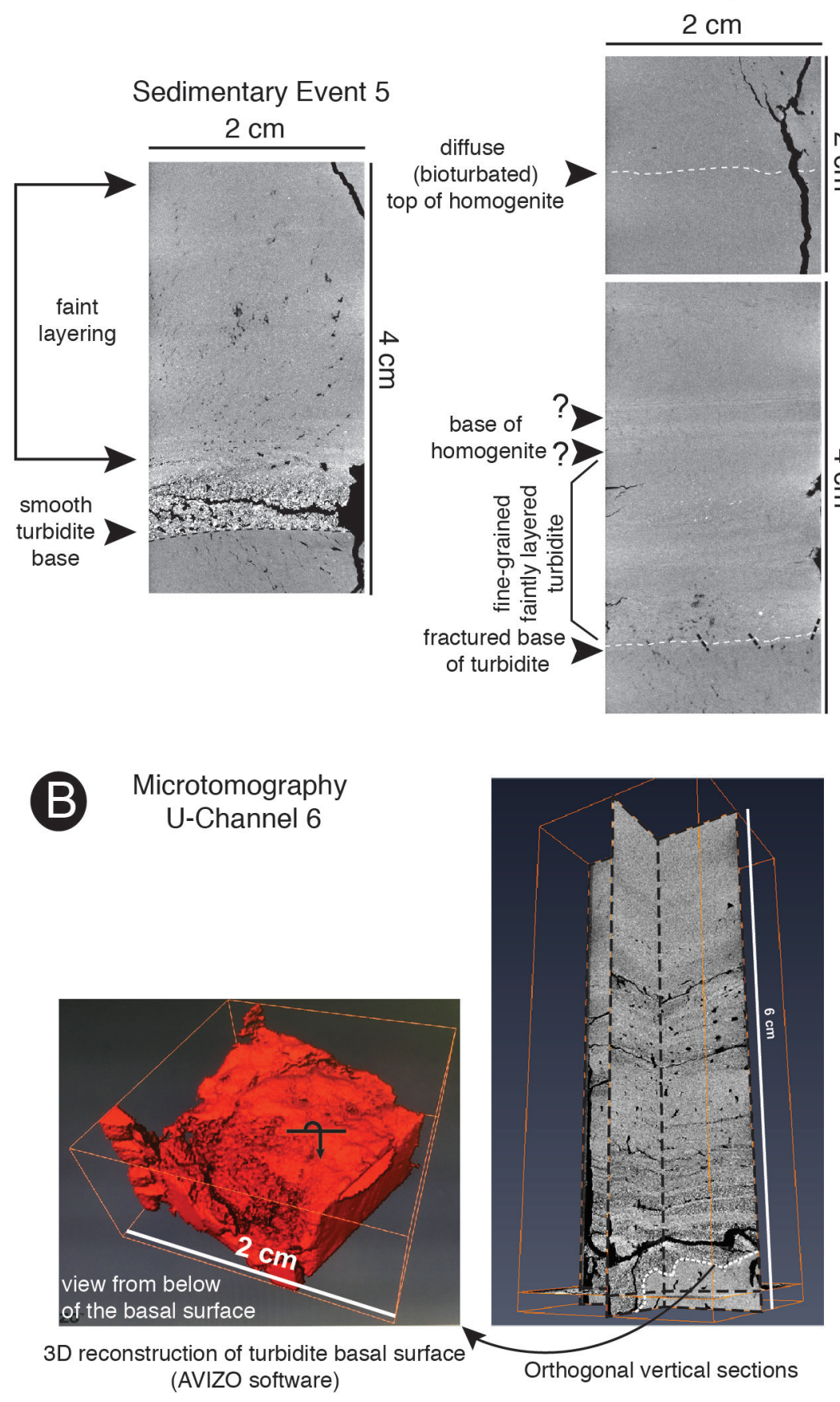

Sedimentary Event 2 $2 \mathrm{~cm}$

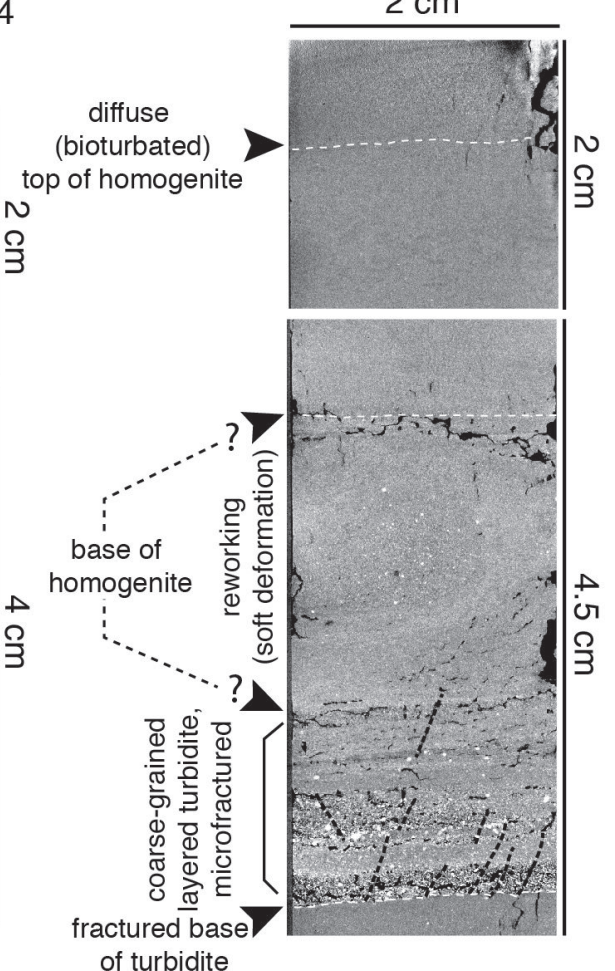

$2 \mathrm{~cm}$

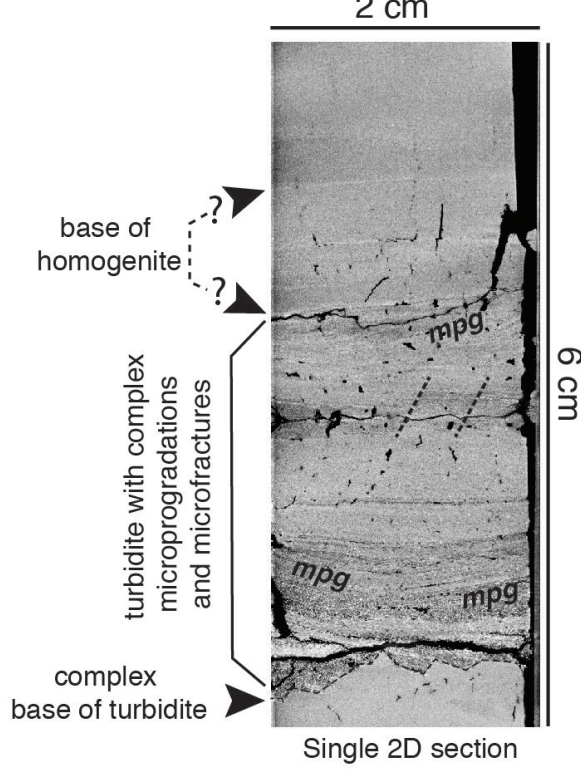

mpg: microprogradation

Figure 8 - X-Ray Microtomography examples for U-Channels 4 and 6 a) 2D images of three sedimentary events in U-Channel 4 (see position in Fig. 6). b) Images of the sedimentary event in U-Channel 6 (same interval as Fig. 7c), including the 3D view of the basal turbidite surface (left), orthogonal sections of the imaged interval (middle) and a single 2D section (right). Microprograding (mpg) features are displayed in 2D; additional microtomographic data on U-channel 6 indicate they display opposite senses. 


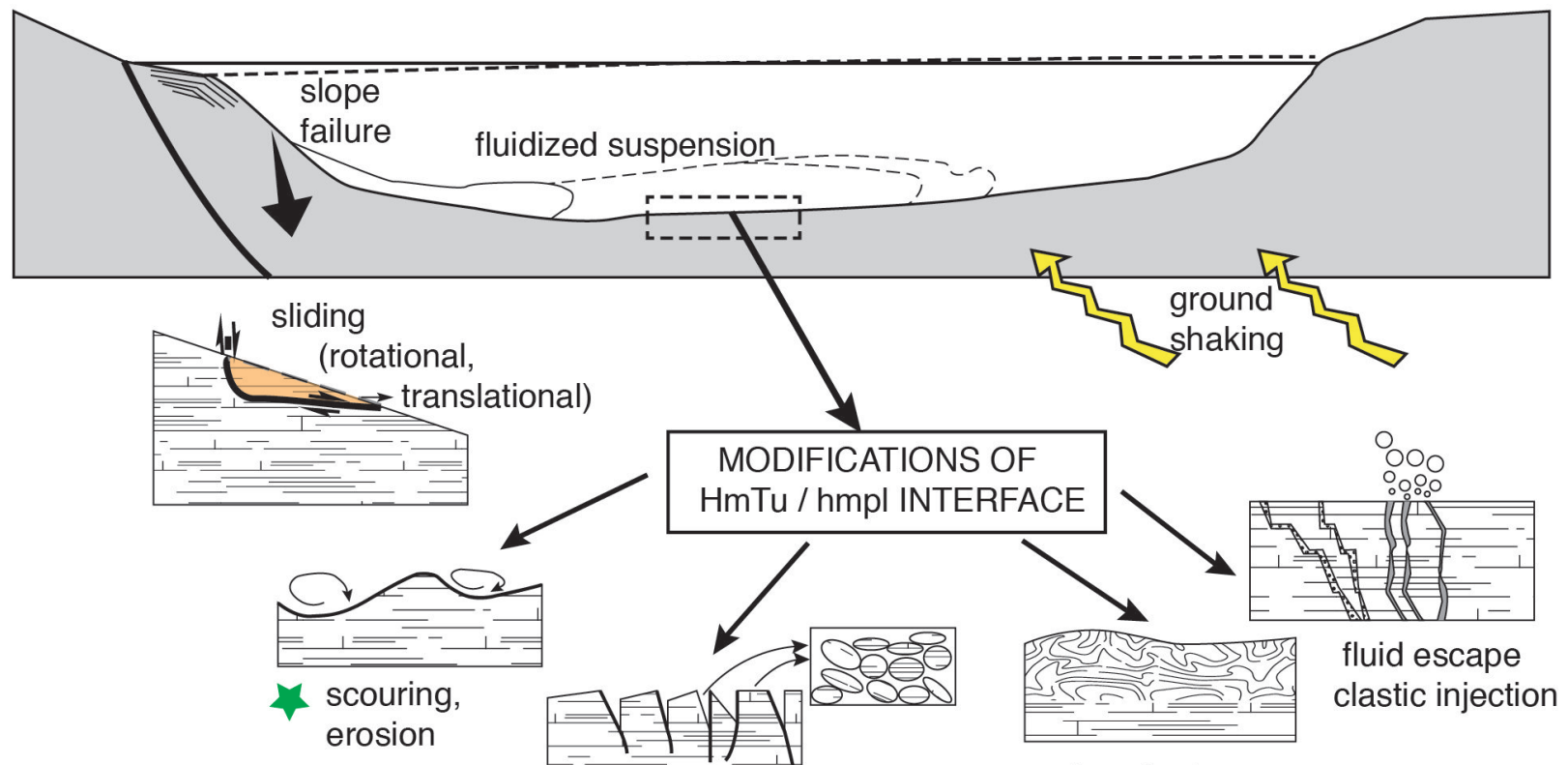

\section{during Homogenite+}

Turbidite event

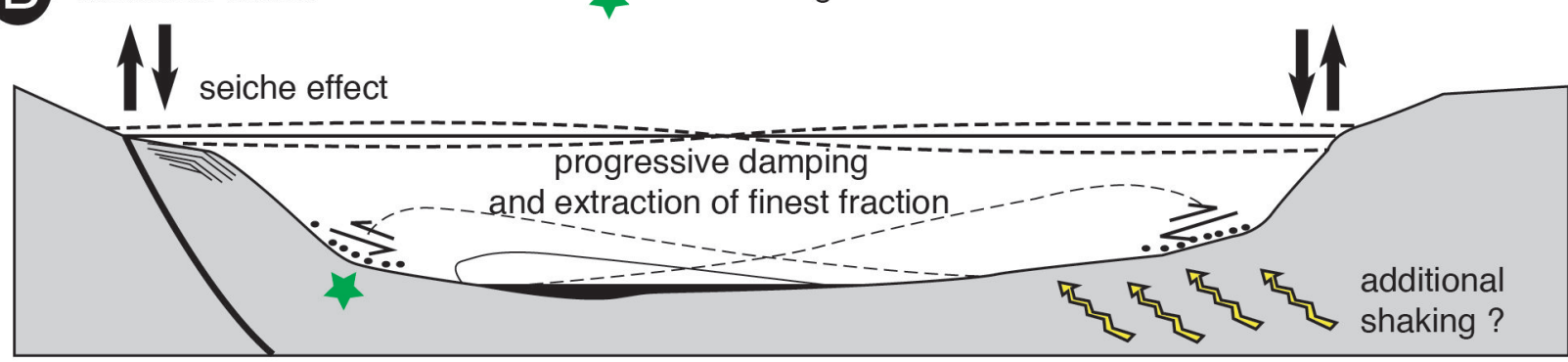

POSSIBLE EVOLUTIONS DURING hm DEPOSITION

A
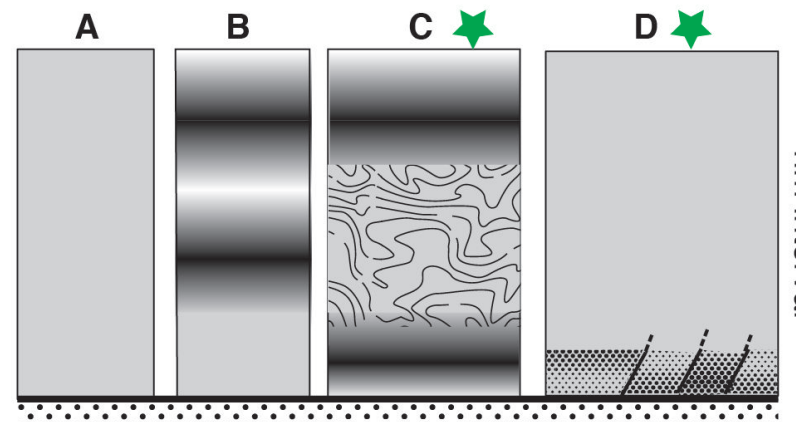

$=58$

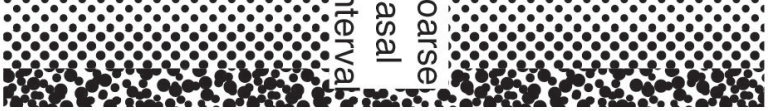

features displayed by X-ray microtomography

A: single monophasic settling

B: intrinsic settling fluctuations

C: disturbance related to ongoing oscillation ( fluage, slumping)

D: intercalation of coarser material by slopes sweeping ; microfracturing related to new shaking episode (depending on rheology/grain size distribution) corresponding synthetic log

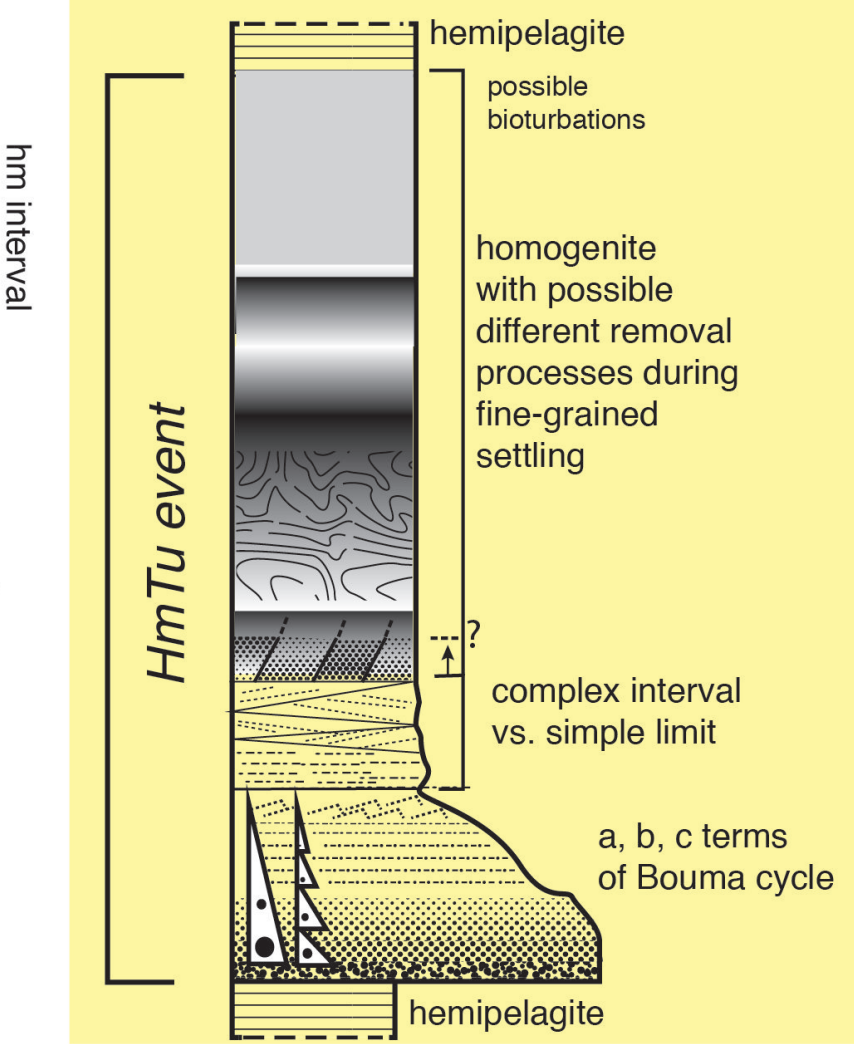

Figure 9.- Explanatory model for HmTu events from U-channels 4 and 6. a) initial triggering and different possible consequences: gravity reworking, water mass movement, and water/sediment interface disturbance; $\mathbf{b}$ ) possible additional effects on settling due to internal (a-A and a-B cases) or external factors ( $\mathrm{a}-\mathrm{C}$ and $\mathrm{a}-\mathrm{D}$ cases); $\mathbf{c}$ ) conceptual model integrating the different inferred mechanisms. Green stars marks particularly well imaged features through X-ray microtomography. To simplify, only one gravity reworking site is represented, but several ones may occur simultaneously from different areas. Adapted from Chapron et al. (1999), Beck et al. (2007), 


\section{Supporting Information for}

\section{Micro-scale sedimentary signature of paleoearthquakes and paleotsunamis in the Corinth Rift (Greece)}

Gino De Gelder ${ }^{1,2}$, Mai Linh Doan ${ }^{1}$, Christian Beck ${ }^{3}$, Julie Carlut ${ }^{2}$, Chloé Seibert ${ }^{2}$, Nathalie Feuillet $^{2}$, Gareth D.O. Carter ${ }^{4}$, Sofia Pechlivanidou ${ }^{5}$, Robert L. Gawthorpe ${ }^{5}$

\footnotetext{
'ISTerre, Université Grenoble-Alpes, 1381 rue de la Piscine, 38400 Saint Martin d'Hères, France, ${ }^{2}$ Université de Paris, Institut de Physique du Globe de Paris, CNRS, F-75005 Paris, France, ${ }^{3}$ ISTerre, Université Savoie-MontBlanc, Campus Scientifique, 73376 Le Bourget-du-Lac Cedex, France, ${ }^{4}$ British Geological Survey, The Lyell Centre, Research Avenue South, Edinburgh, EH14 4AP, United Kingdom, ${ }^{5}$ Department of Earth Science, University of Bergen, Postboks 7803 NO-5020 Bergen, Norway
}

\section{Contents of this file}

Supplementary Figures 1-5, Supplementary Table 1

\section{Introduction}

Supplementary Fig. 1 shows Principal Component Analysis results of 24 selected XRF ratios (see Methods), whereas Supplementary Fig. 2 shows XRF counts of specific elements. Supplementary Fig. 3 and 4 show XRF, grainsize/-shape, magnetic and microtomography analyses of U-channels not presented in the main paper, and Supplementary Fig. 5 additional microtomographic images of U-channels 2 and 8. Supplementary Table 1 gives an overview of observations and interpretations of the sedimentary events in all uchannels. 


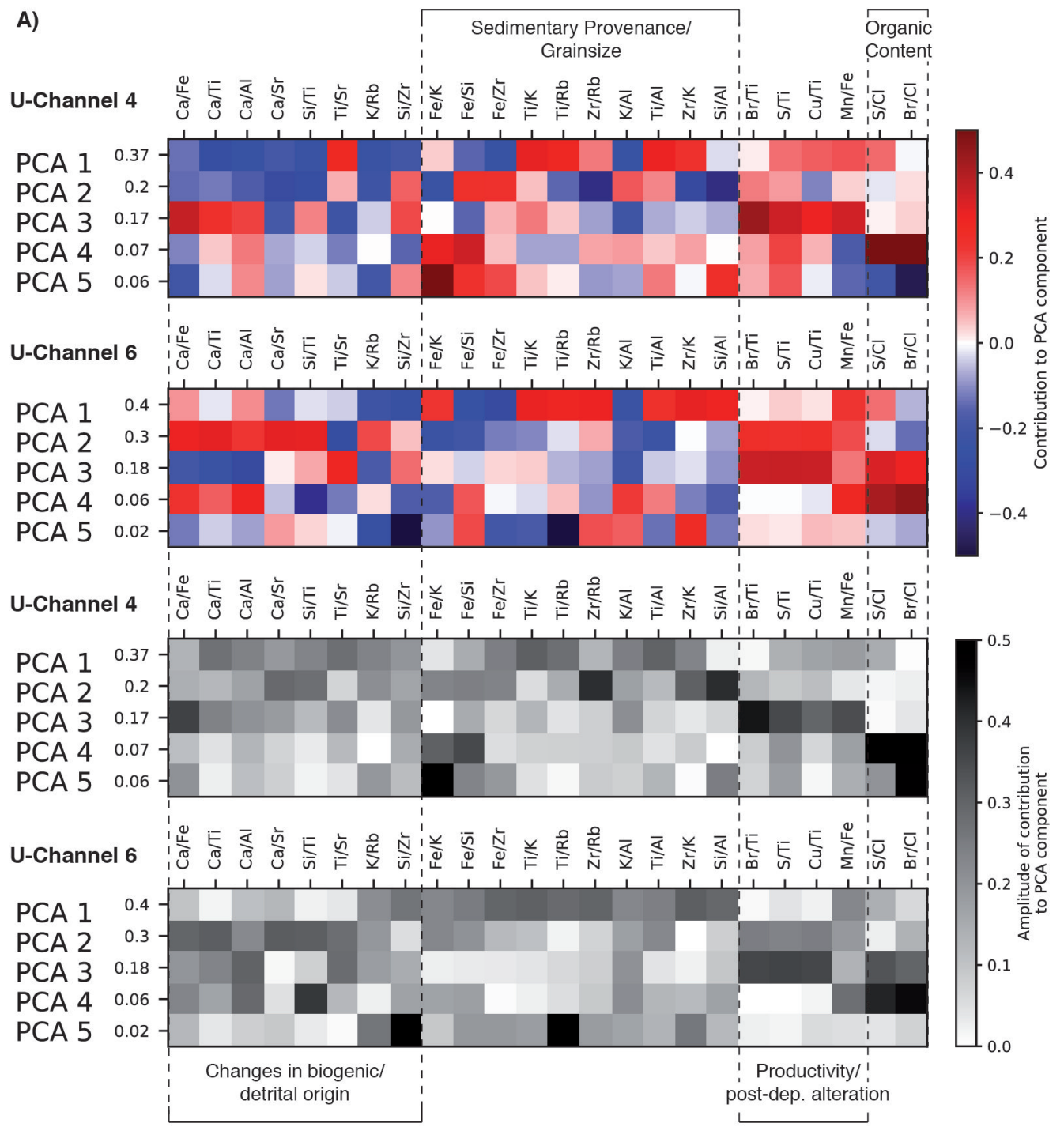

Supplementary Figure 1: X-Ray Fluorescence (XRF) Principal Component Analysis of U-Channels.

Showing the first 5 Principal Components and the normalized weight of each component for 24 XRF ratios, for a) U-Channels 4 and 6, both in color code and black/white b) U-Channels 1, 2, 3, 7, 8 in color code and c) in black/white 
B)

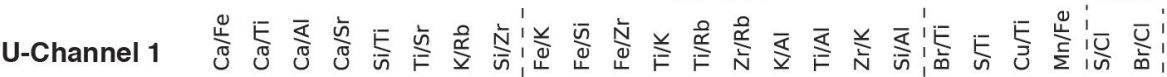

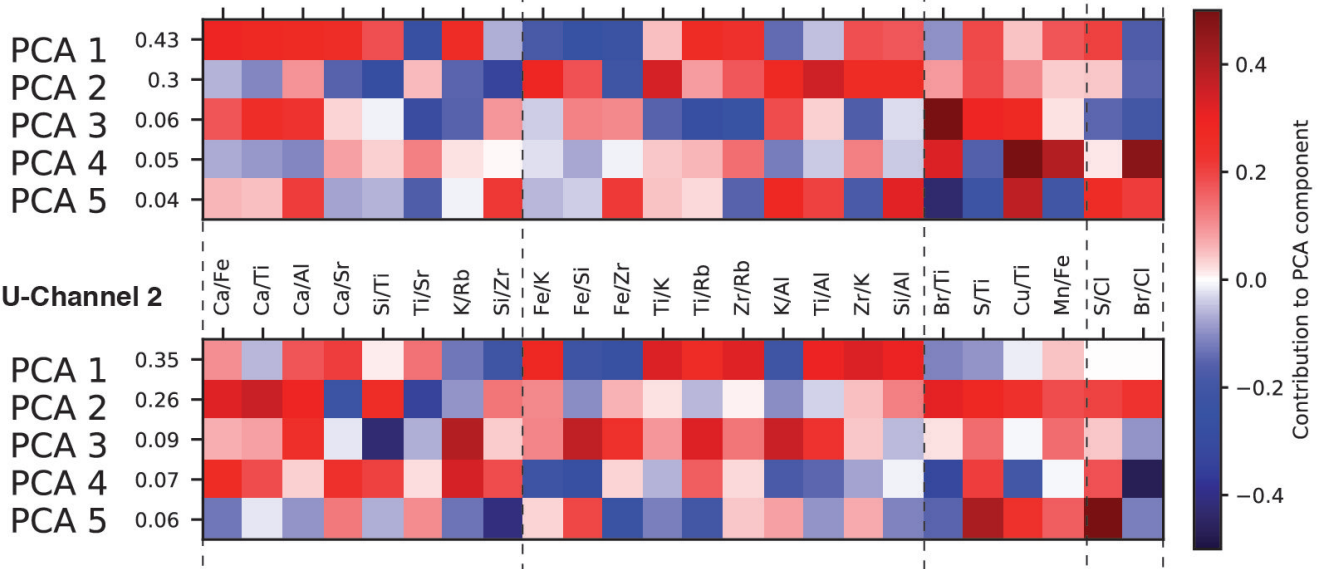

U-Channel 3 绕

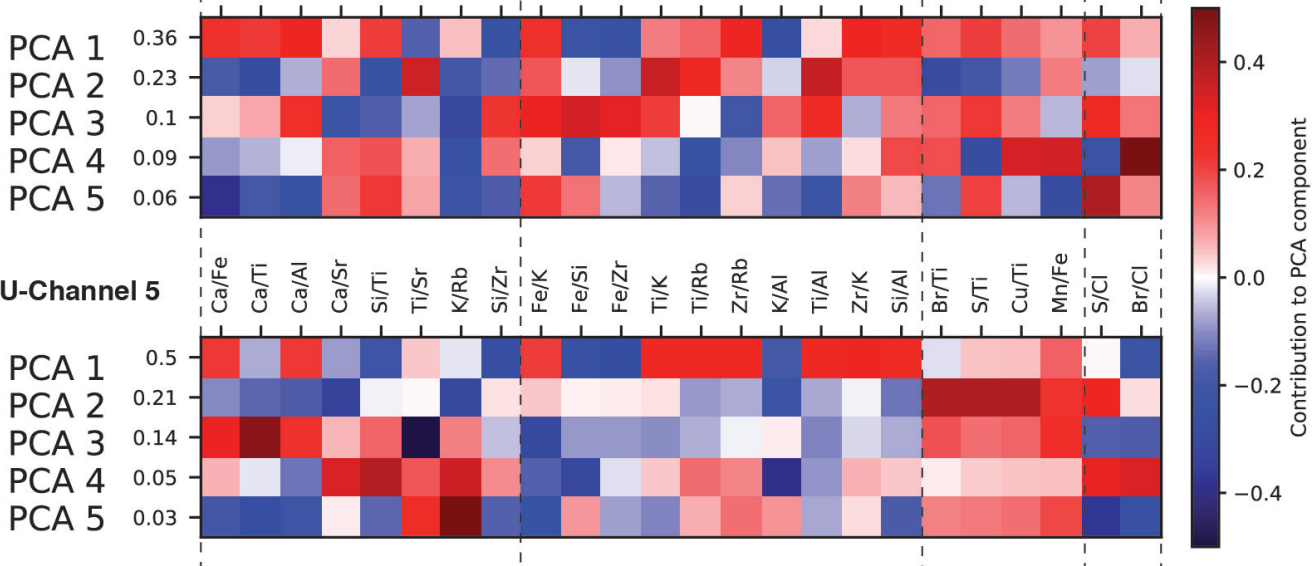

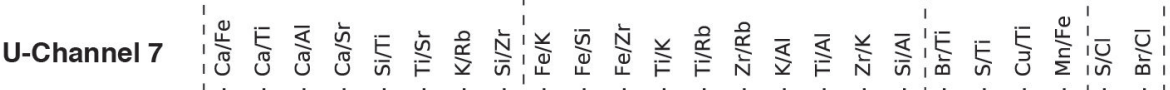

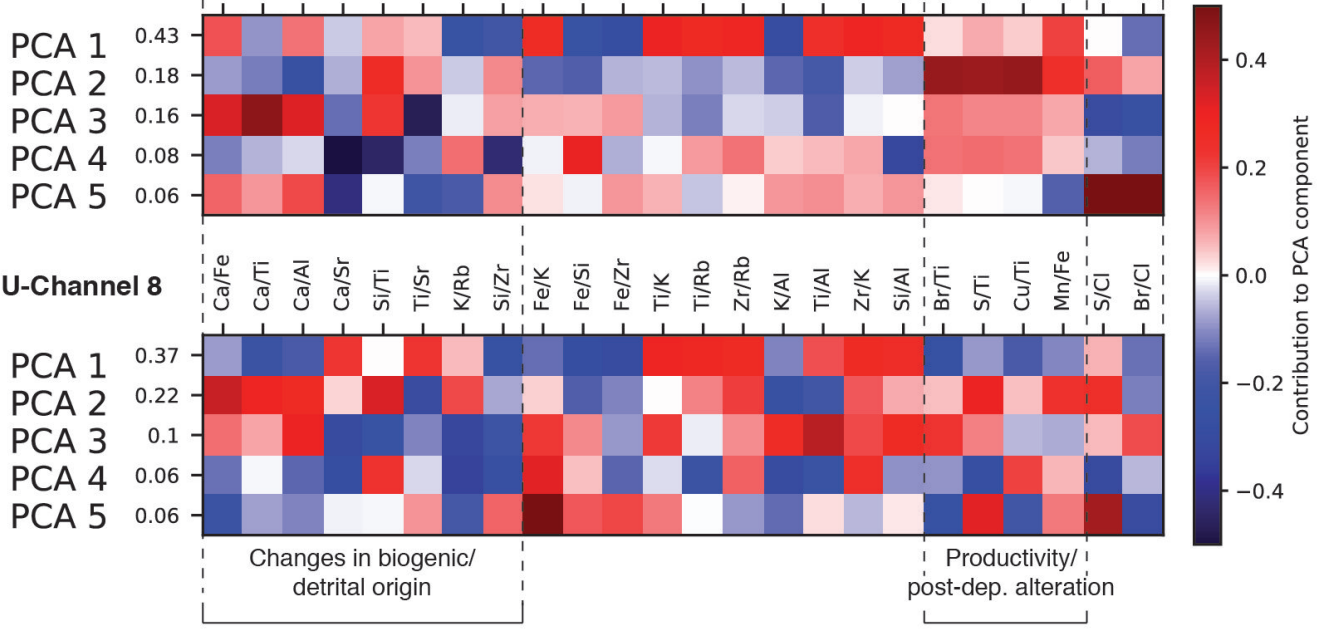


C)

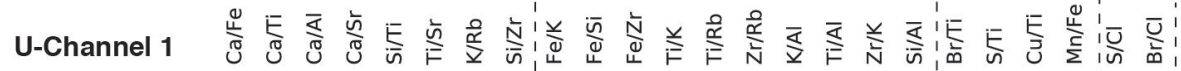

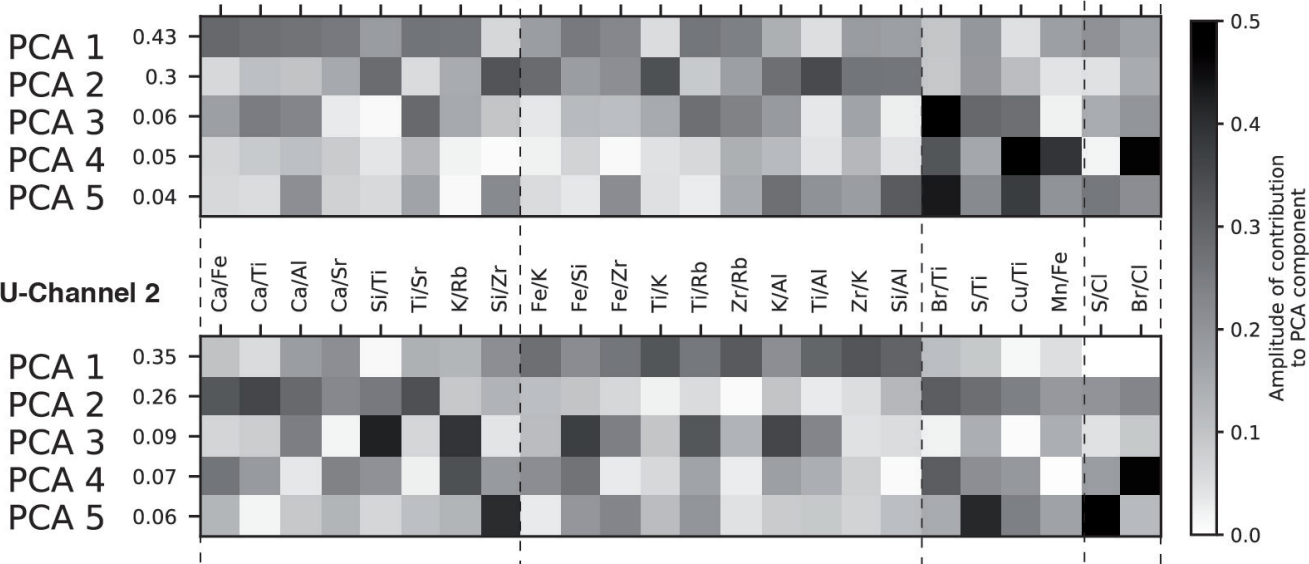

U-Channel 3 倍

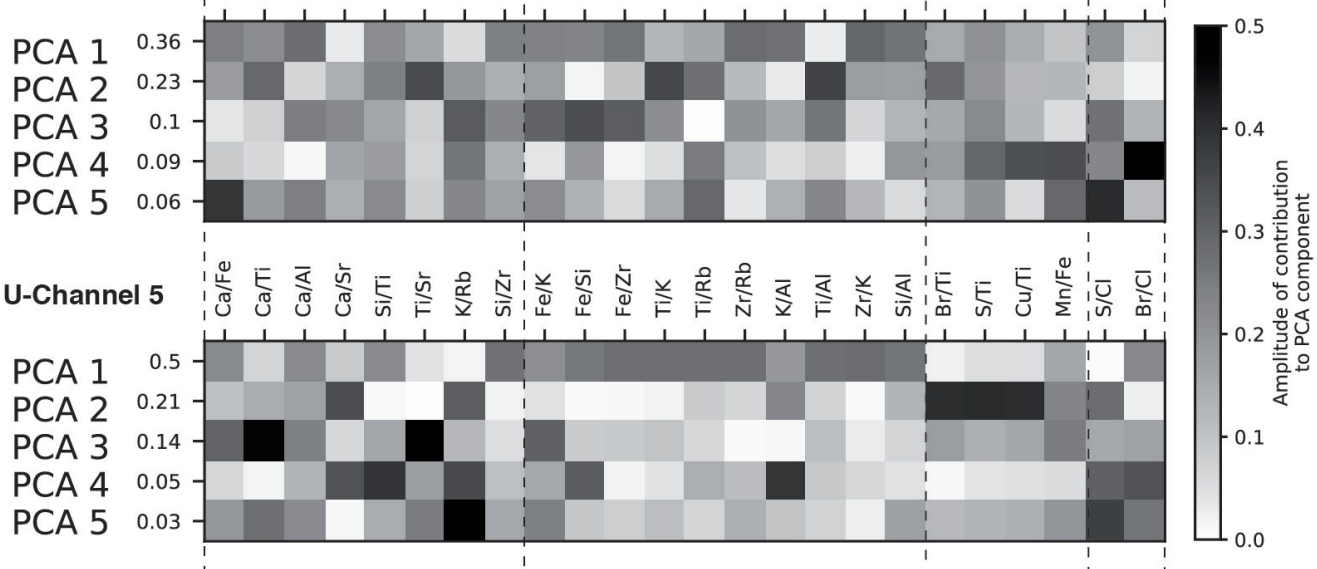

U-Channel 7 :

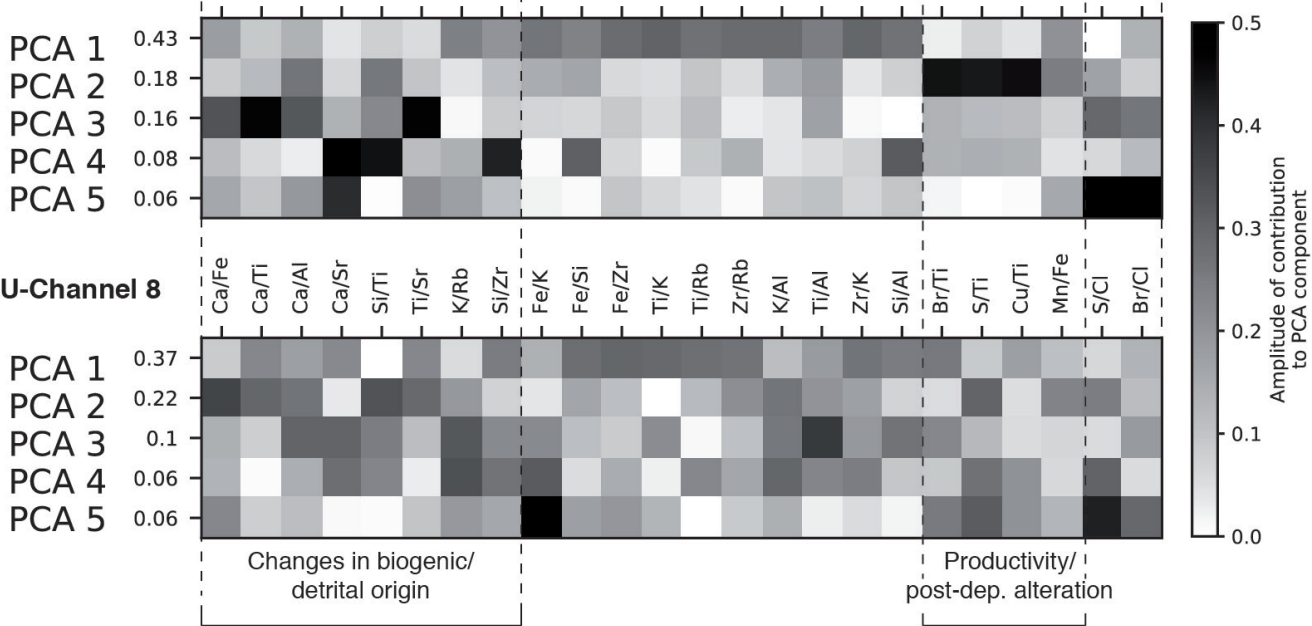




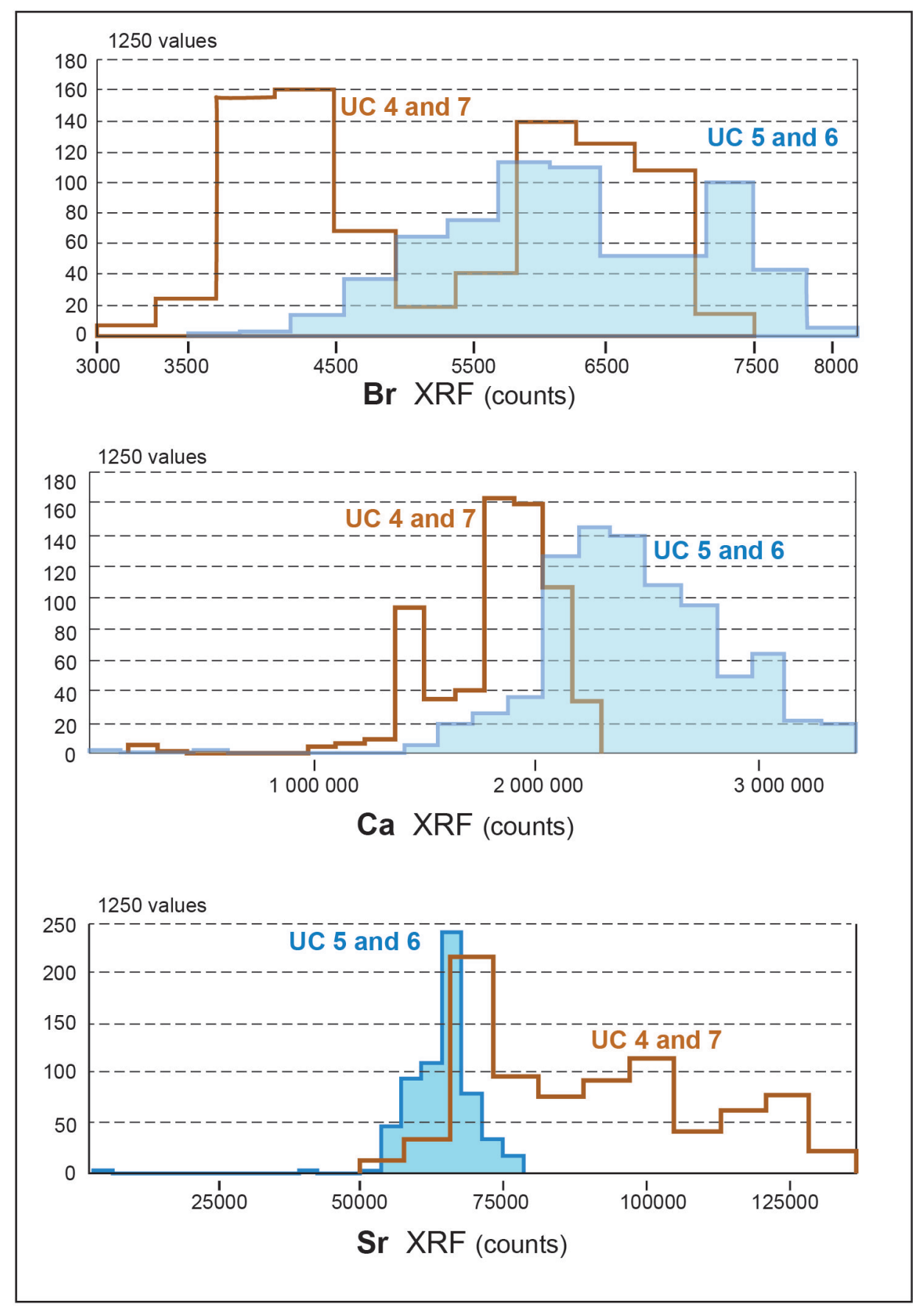

Supplementary Figure 2: Compared distribution of XRF $\mathrm{Ca}, \mathrm{Br}$, $\mathrm{Sr}$ counts within marine and (semi-)isolated U-channels. U-channels 5 and 6 representing marine conditions, and U-channels 4 and 7 representing (semi-)isolated conditions. 

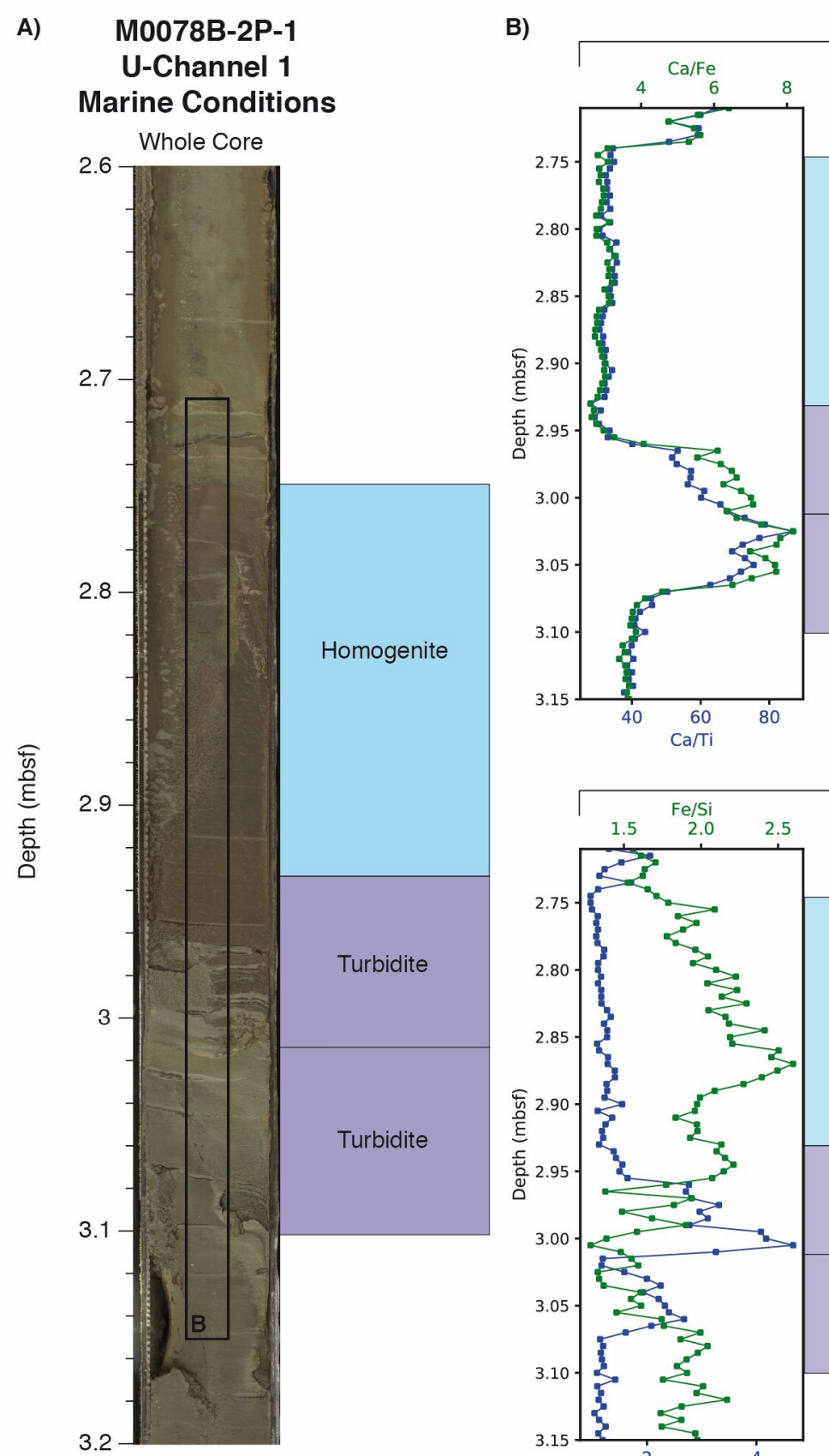

Changes in biogenic/detrital origin

Productivity/post-depositional alteration
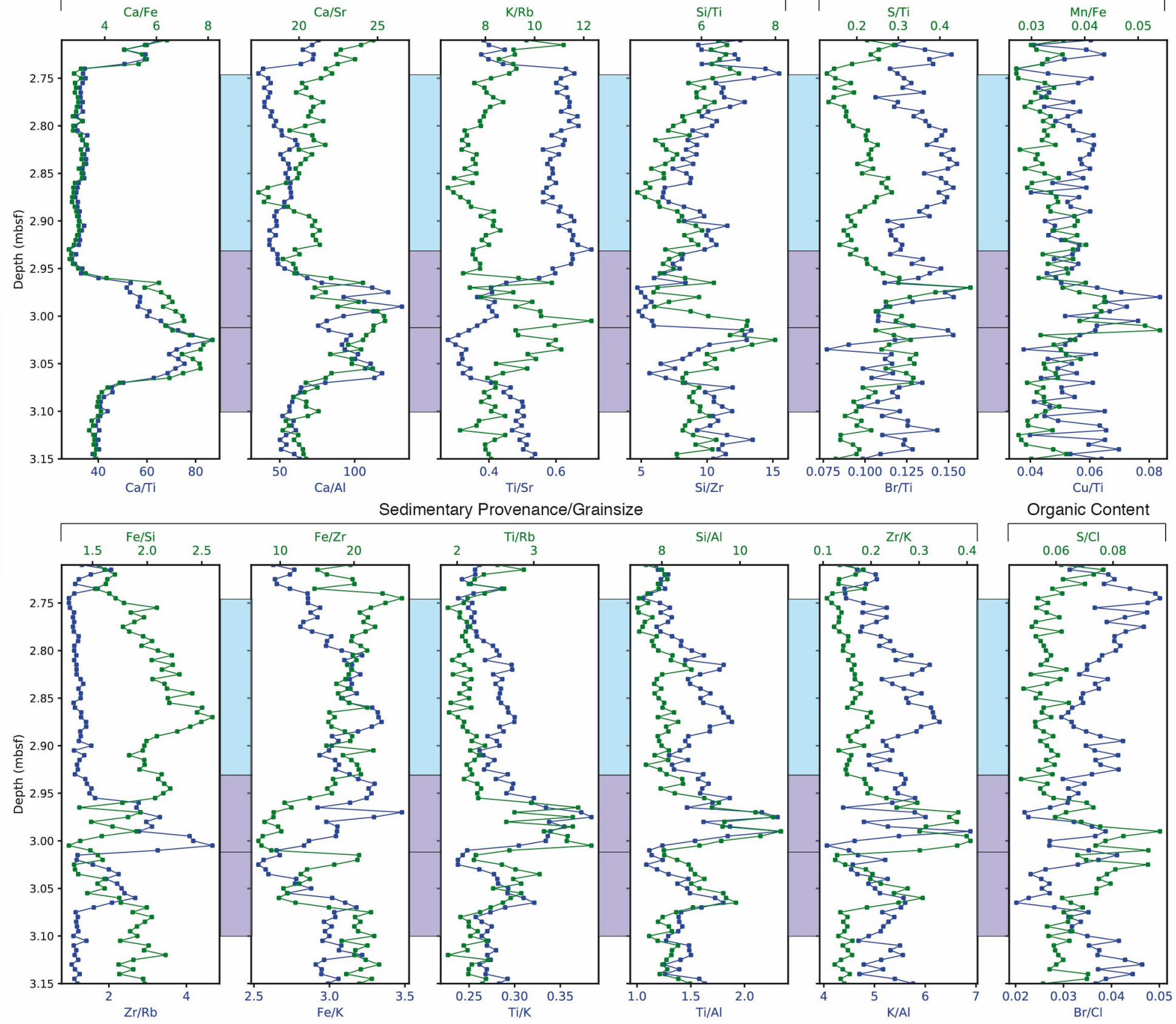

Supplementary Figure 3: X-Ray Fluorescence (XRF) ratios for all U-Channels (8 pages). Selection of $24 \mathrm{XRF}$ ratios, measured on the whole core at $5 \mathrm{~mm}$ resolution for U-Channels $1,2,3,8$ and measured on the $u$-channel at $1 \mathrm{~mm}$ resolution for U-Channels $4,5,6$ and 7 
M0078B-7P-2

U-Channel 2

Marine Conditions

Whole Core

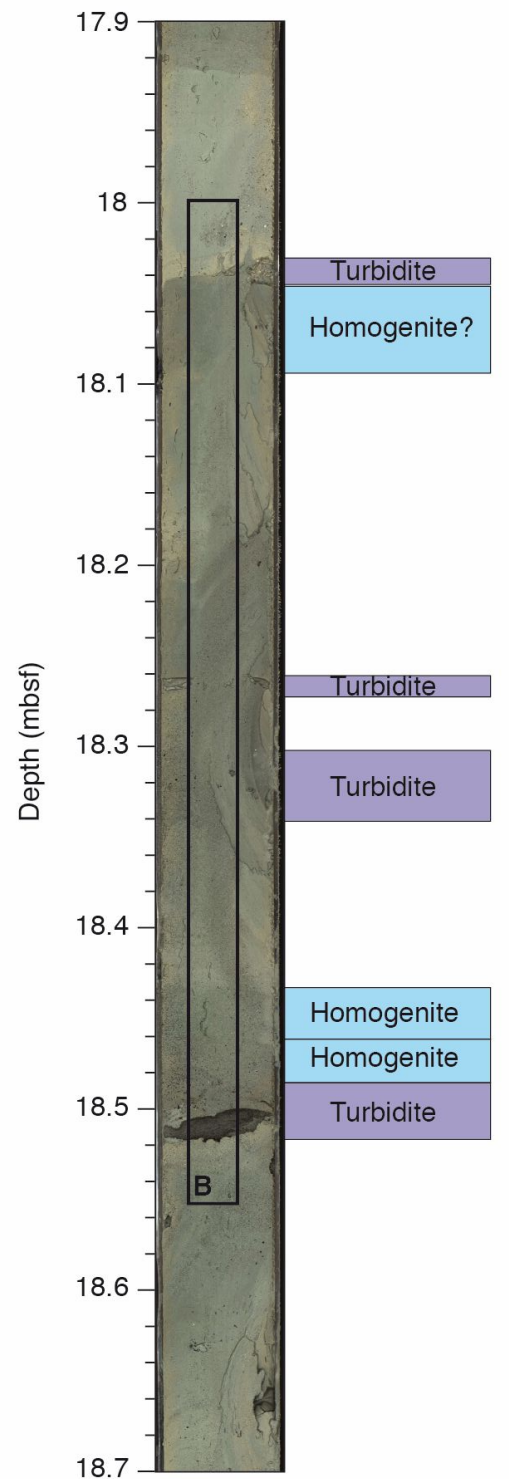

B)

Changes in biogenic/detrital origin

Productivity/post-depositional alteration
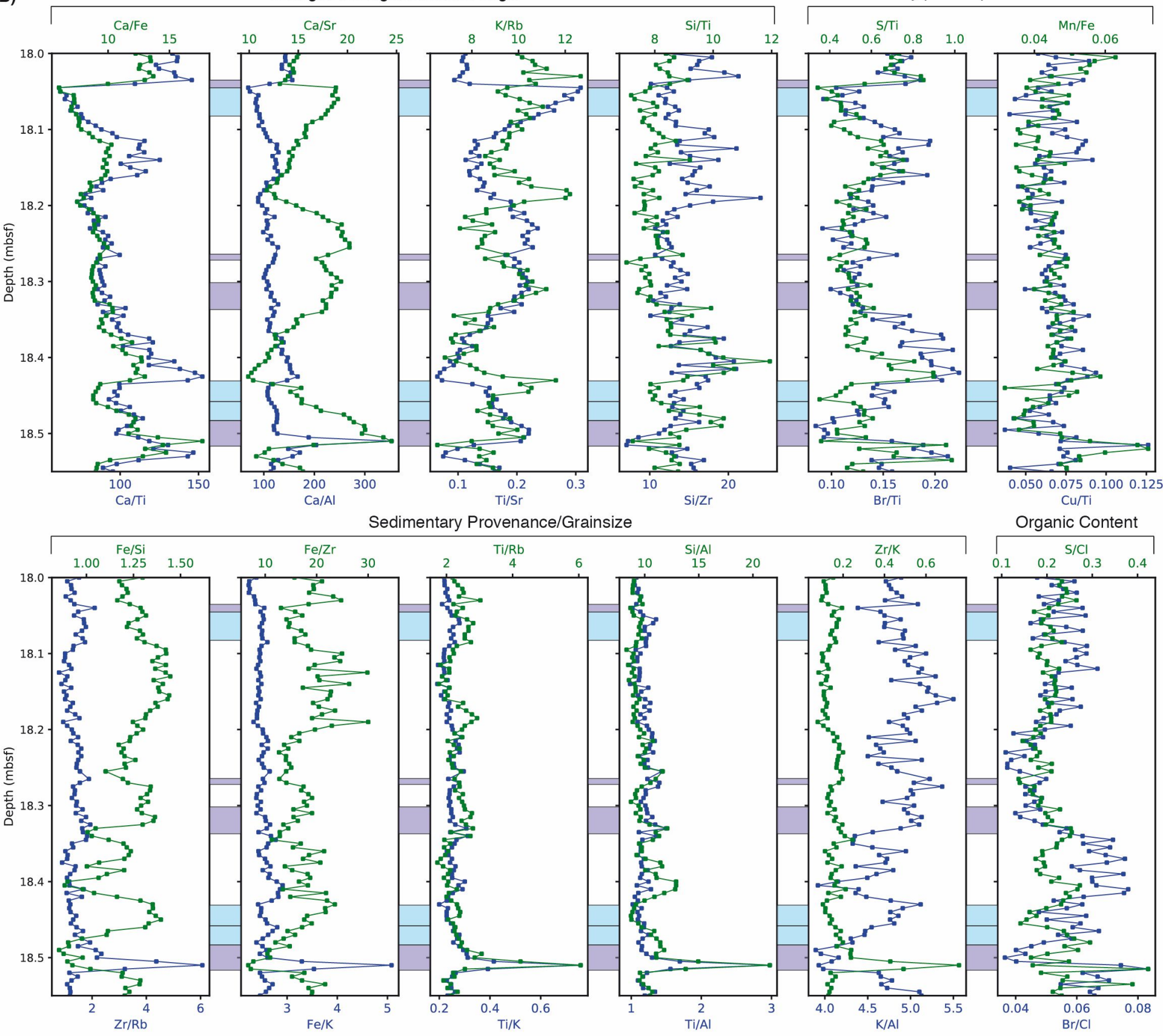
M0078B-8P-3

U-Channel 3

(Semi-)Isolated Conditions

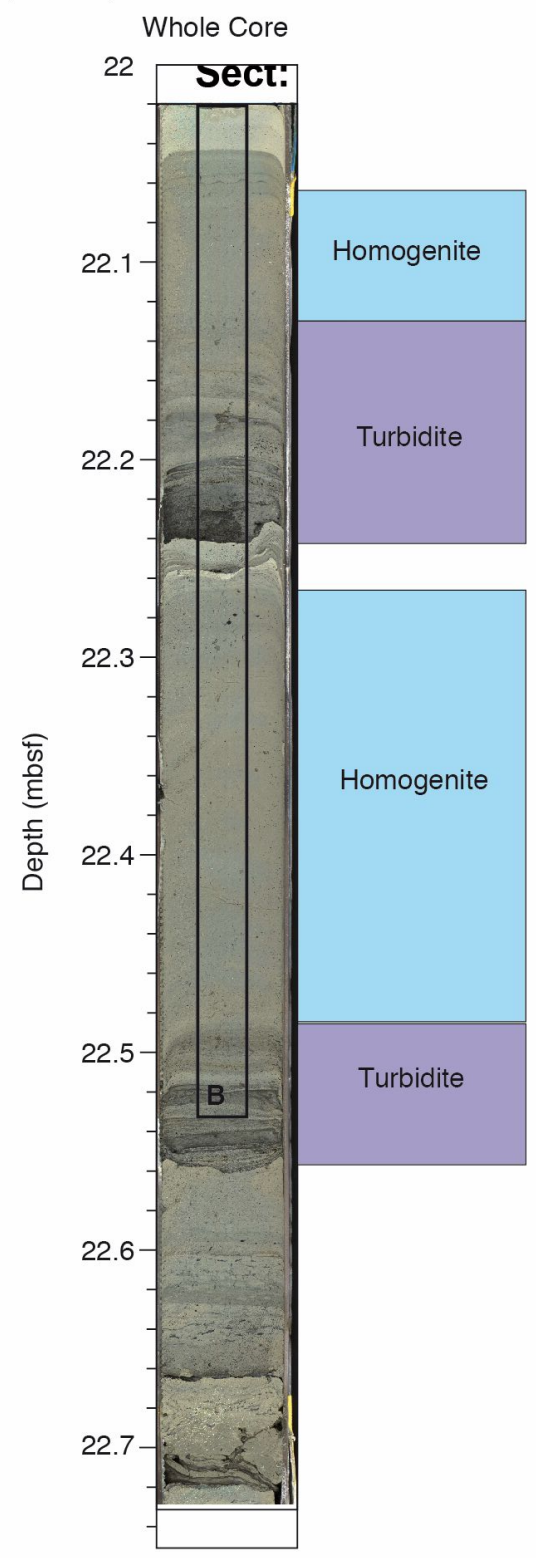

B)

Changes in biogenic/detrital origin
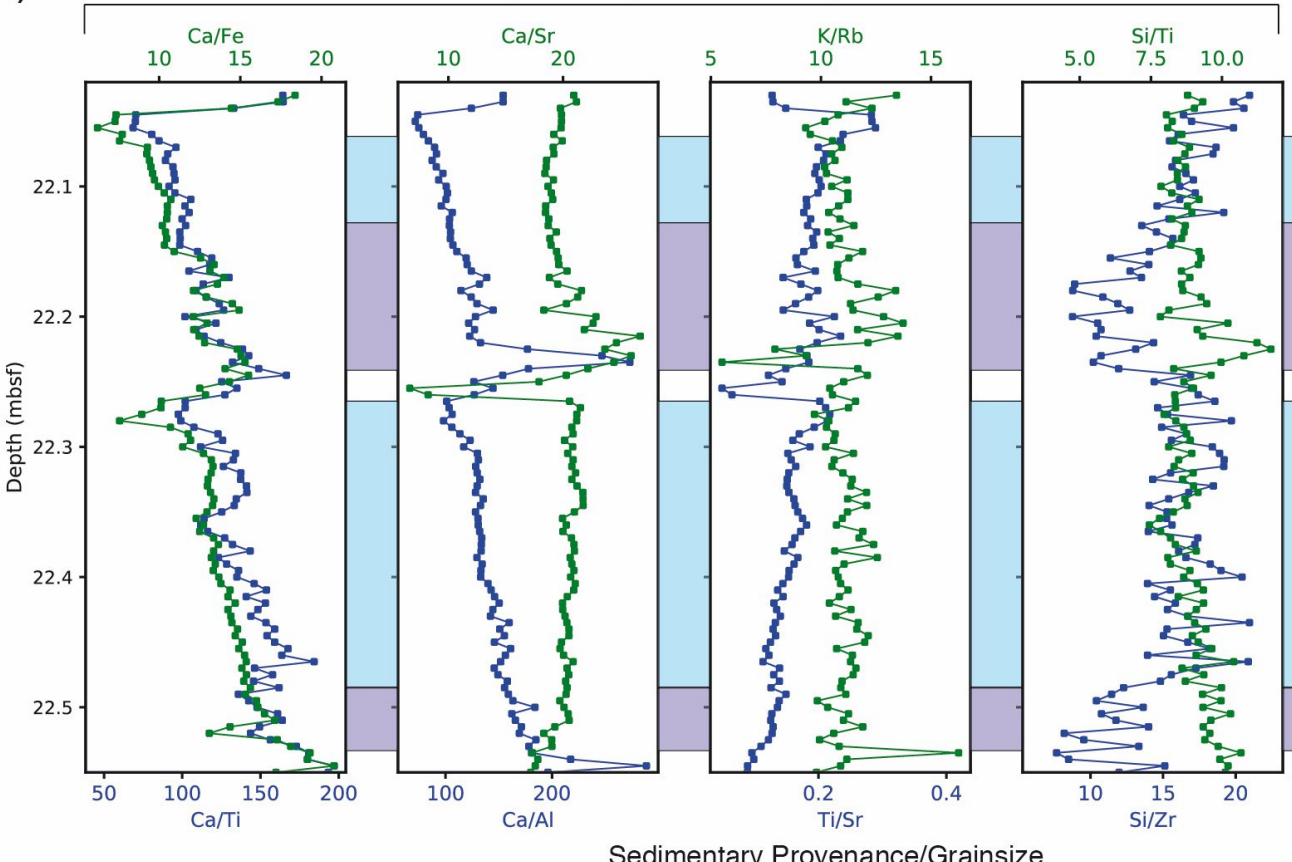

Productivity/post-depositional alteration
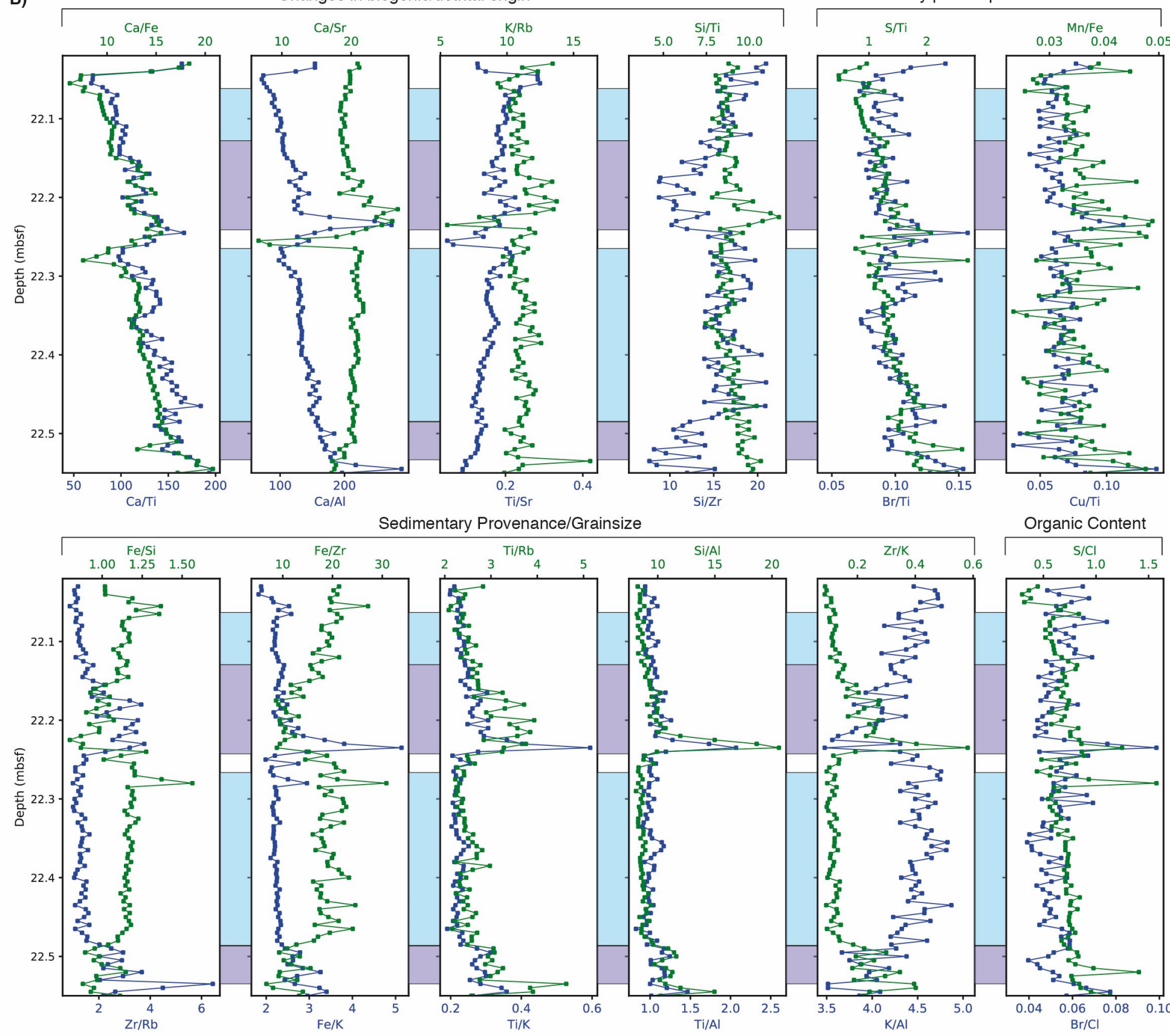

Cu/Ti

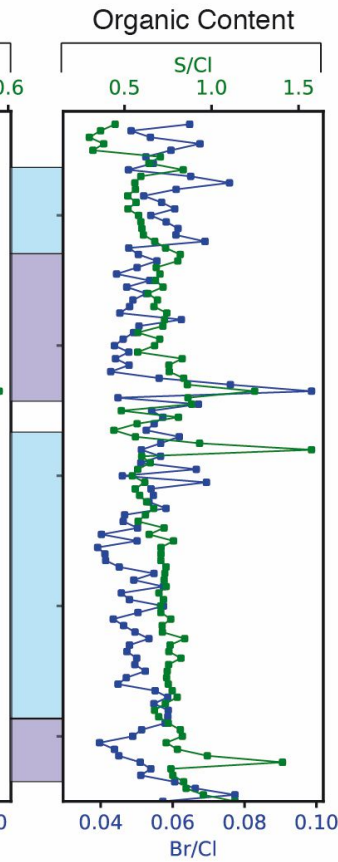


M0078B-12P-3

U-Channel 4

(Semi-)lsolated conditions

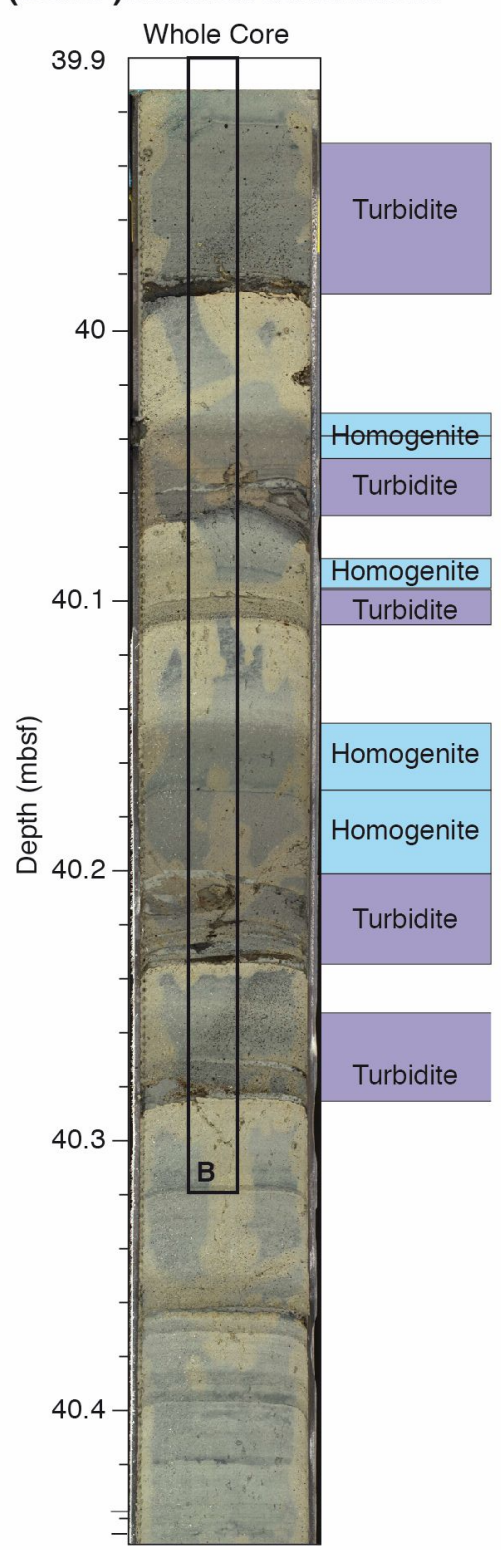

B)

Changes in biogenic/detrital origin

Productivity/post-depositional alteration

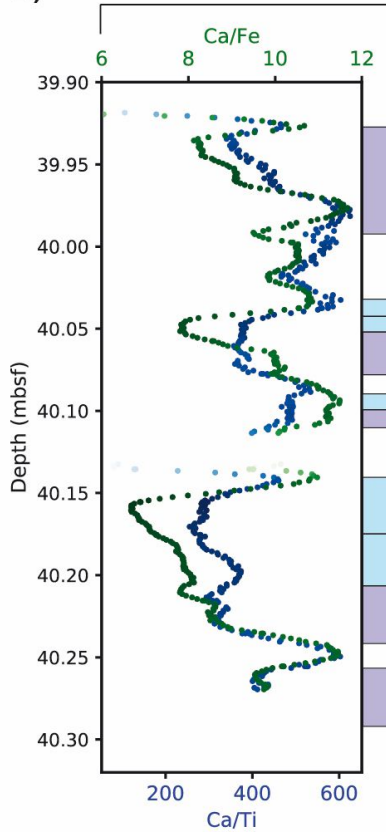

$\mathrm{Ca} / \mathrm{Sr}$
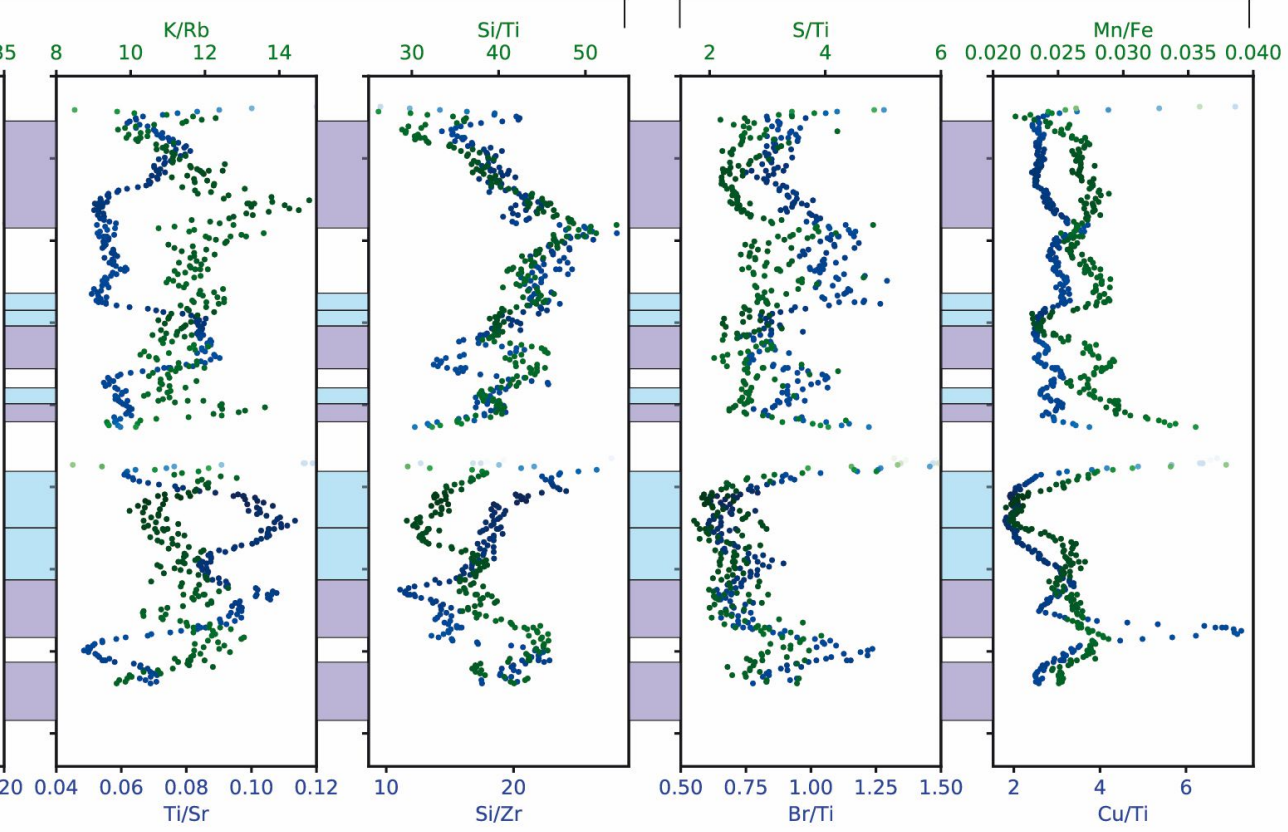
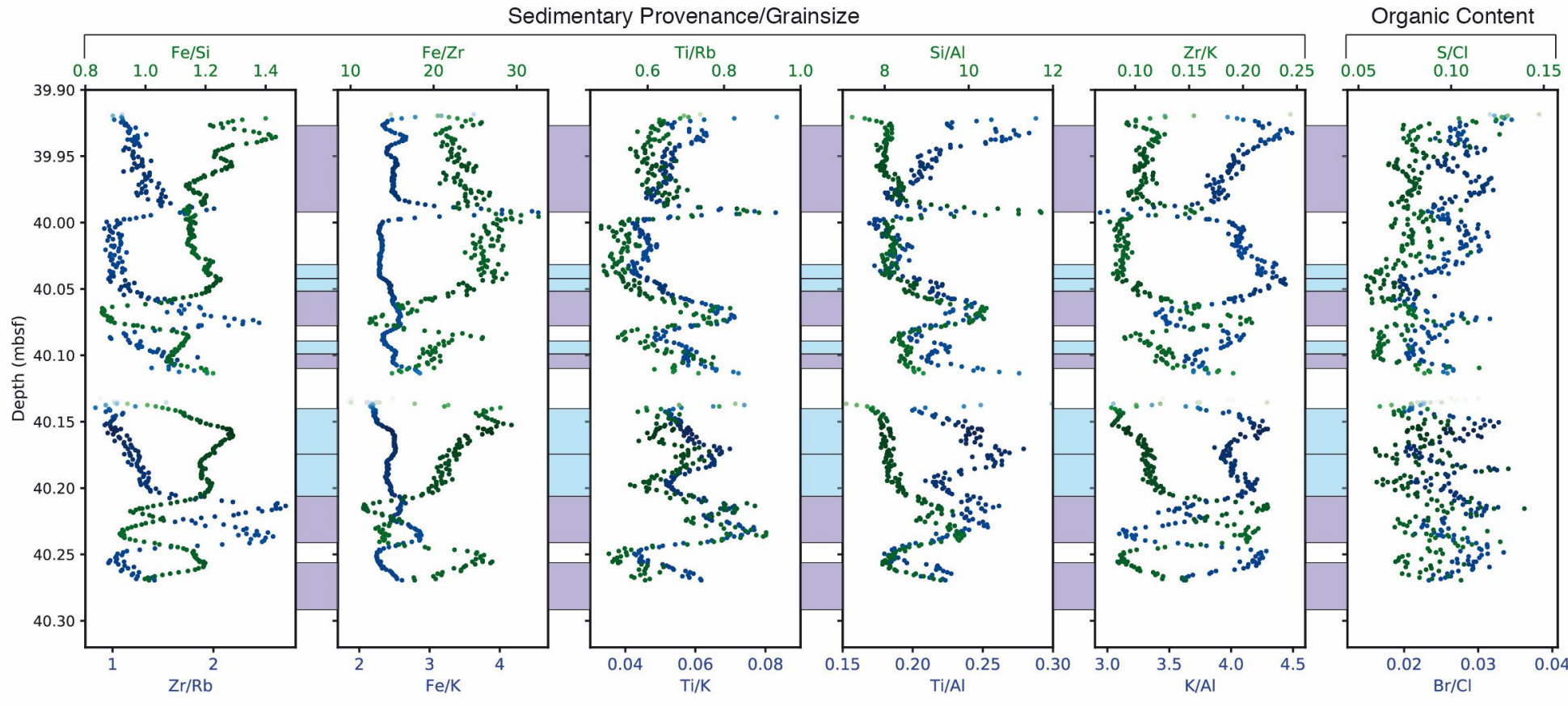


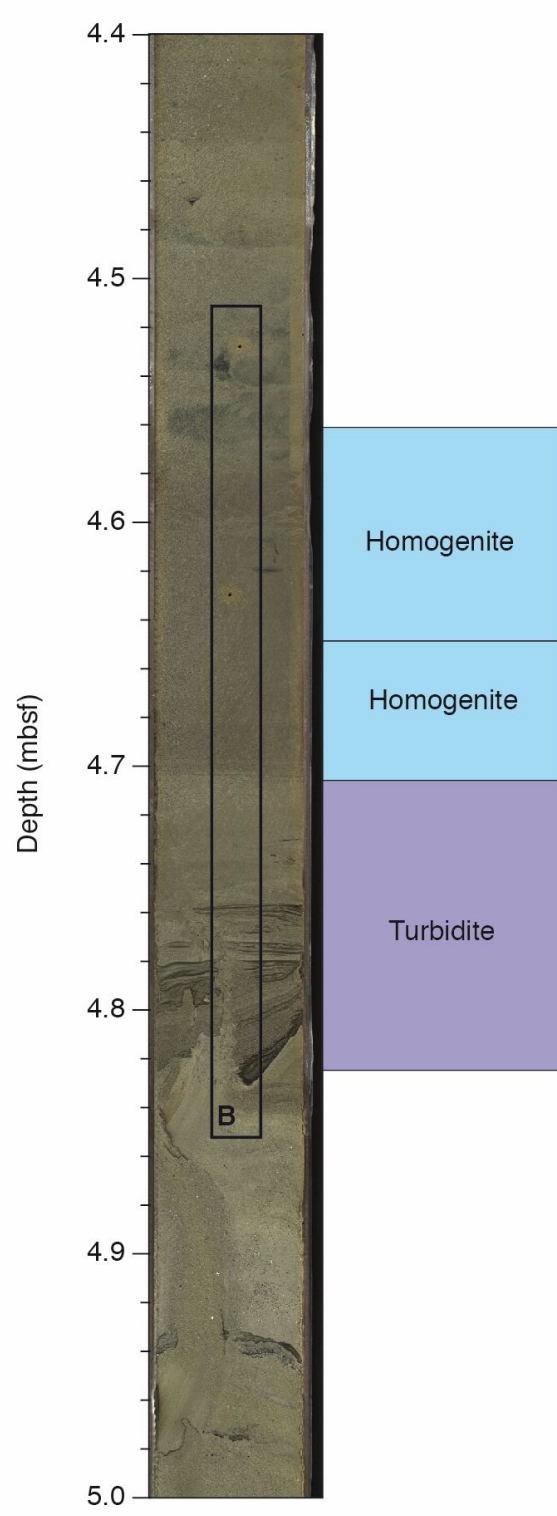

B)

Changes in biogenic/detrital origin
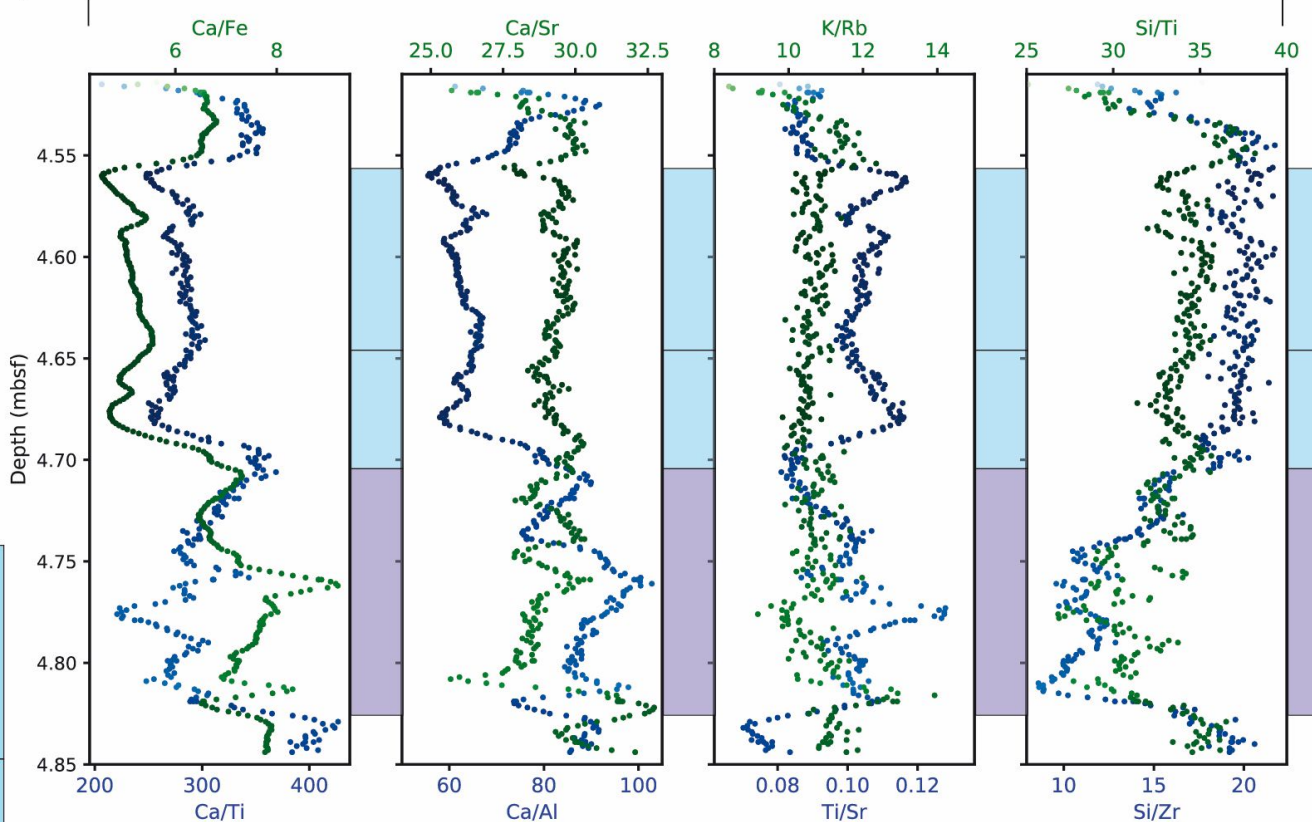

Productivity/post-depositional alteration
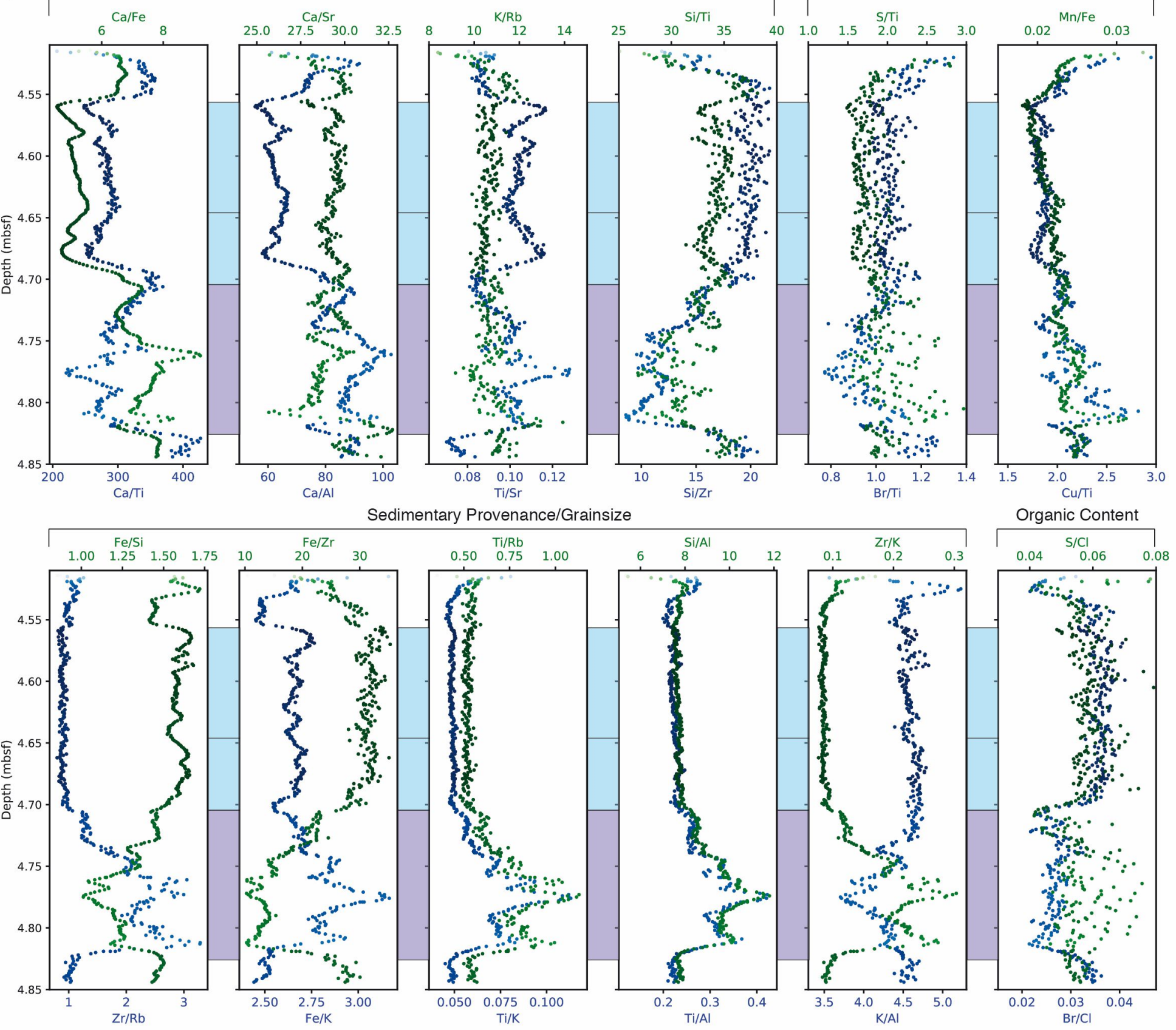
M0079A-6P-3

U-Channel 6 Marine Conditions 19.8 Whole Core

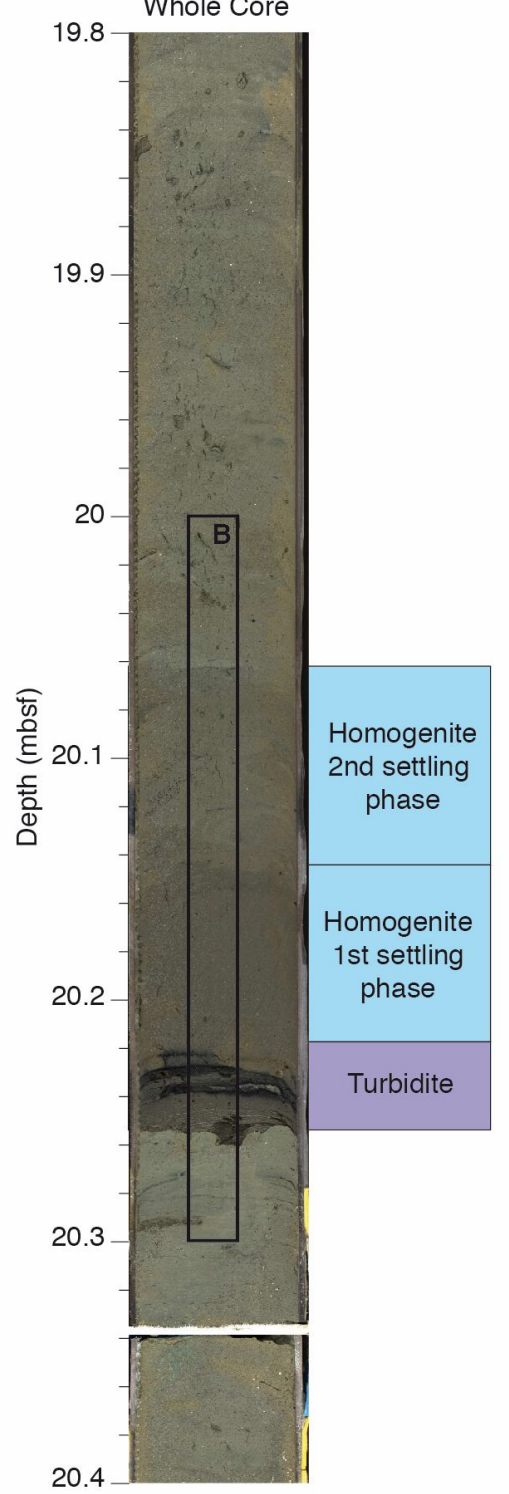

B)

Changes in biogenic/detrital origin
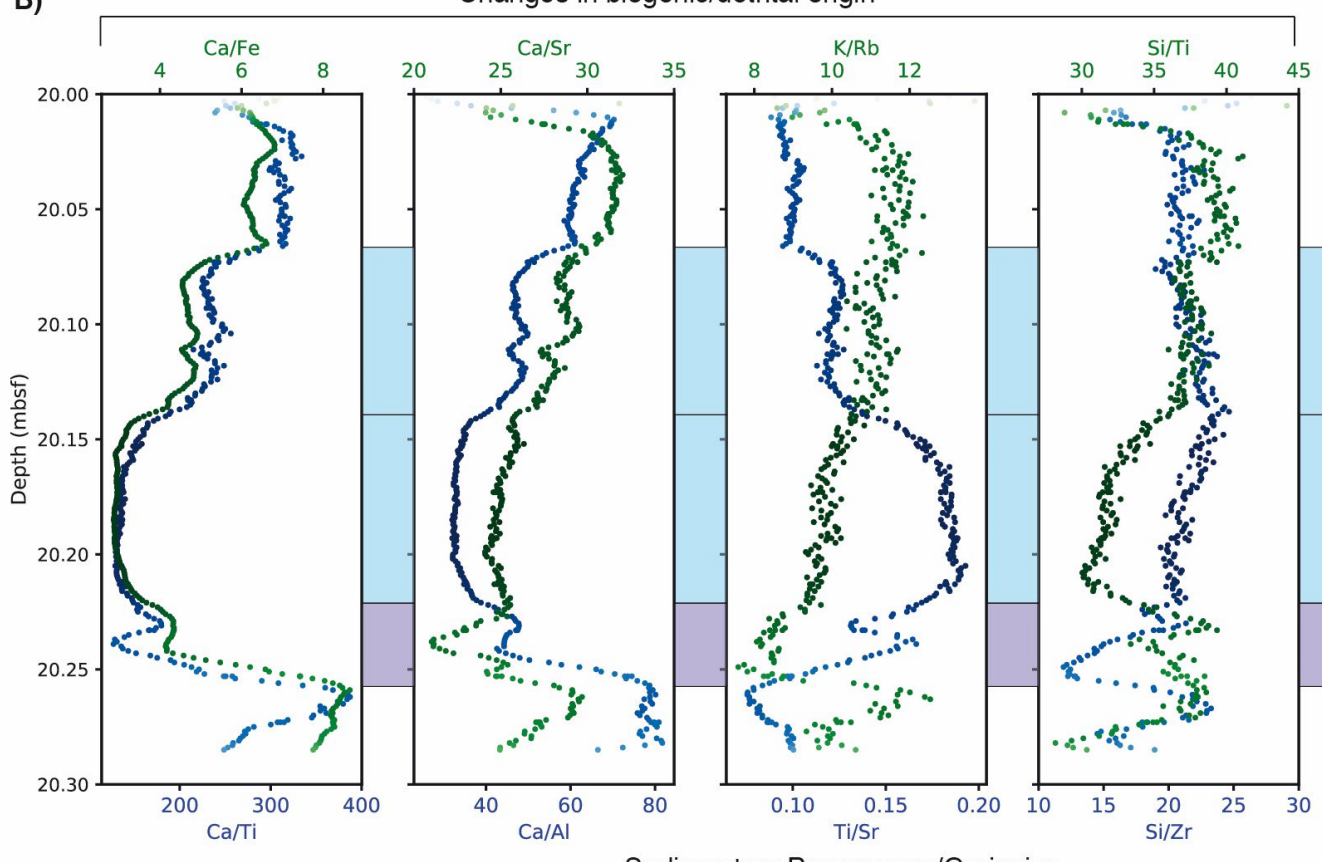

Productivity/post-depositional alteration
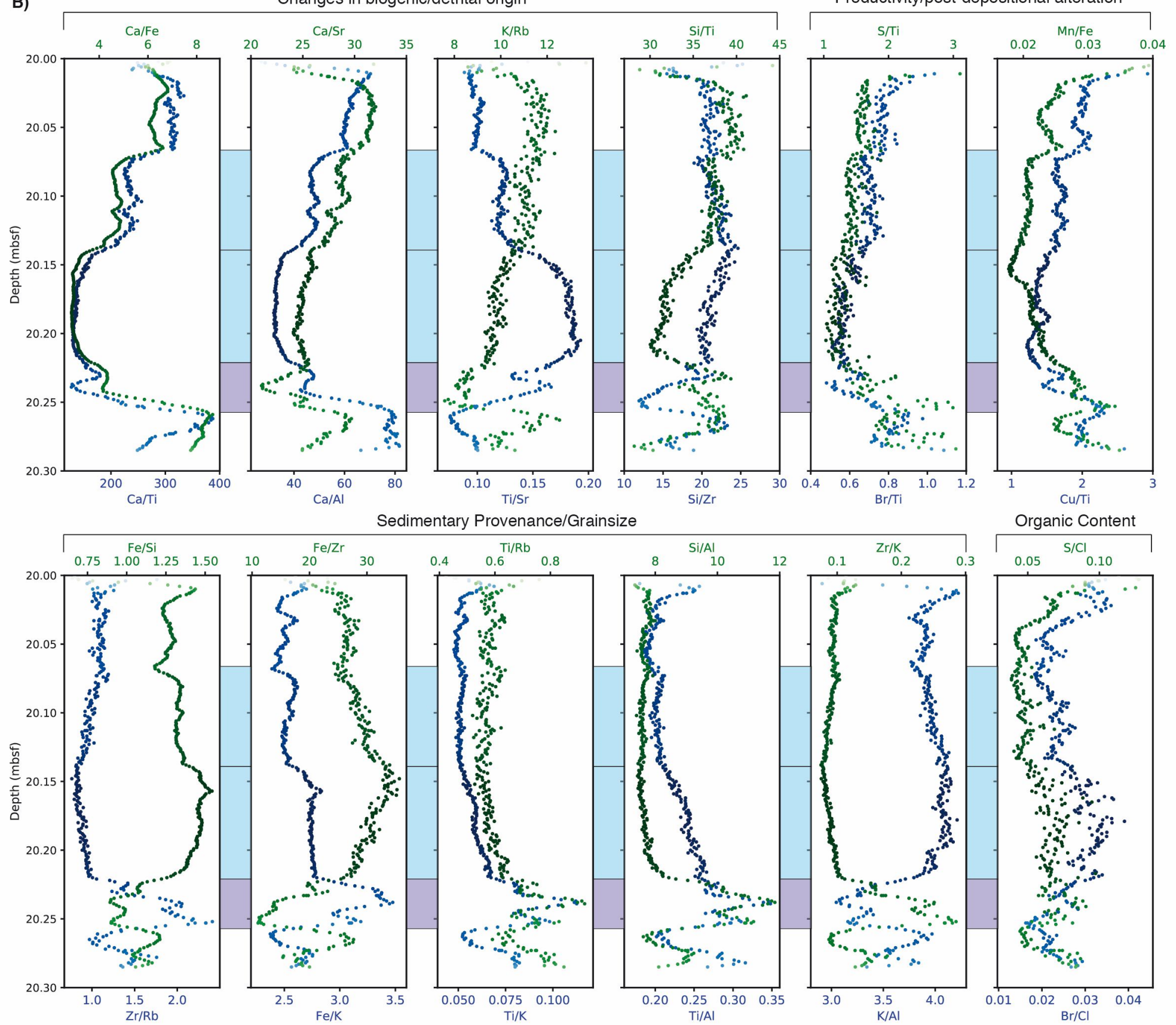

Organic Content
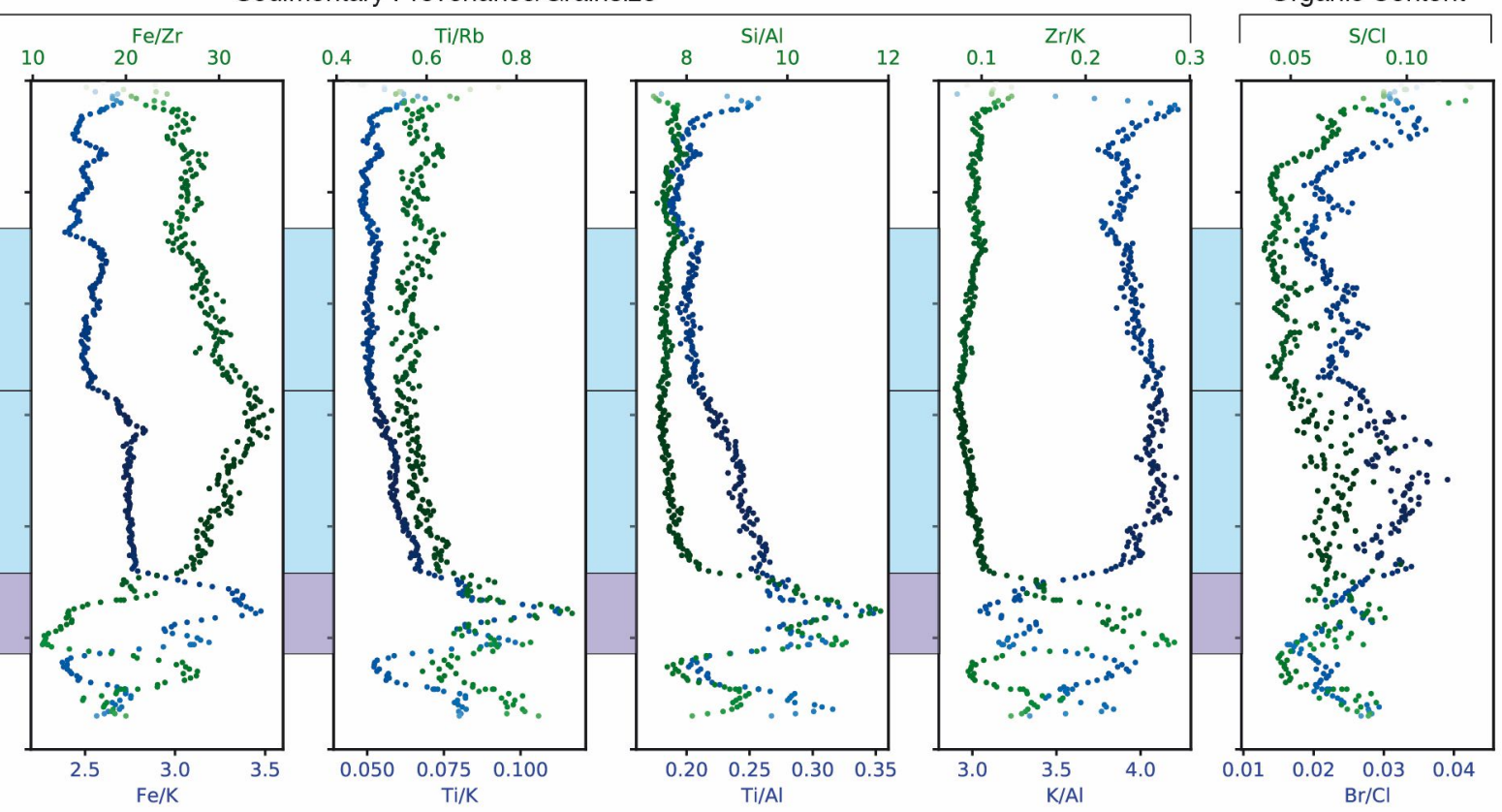
(Semi-)Isolated Conditions

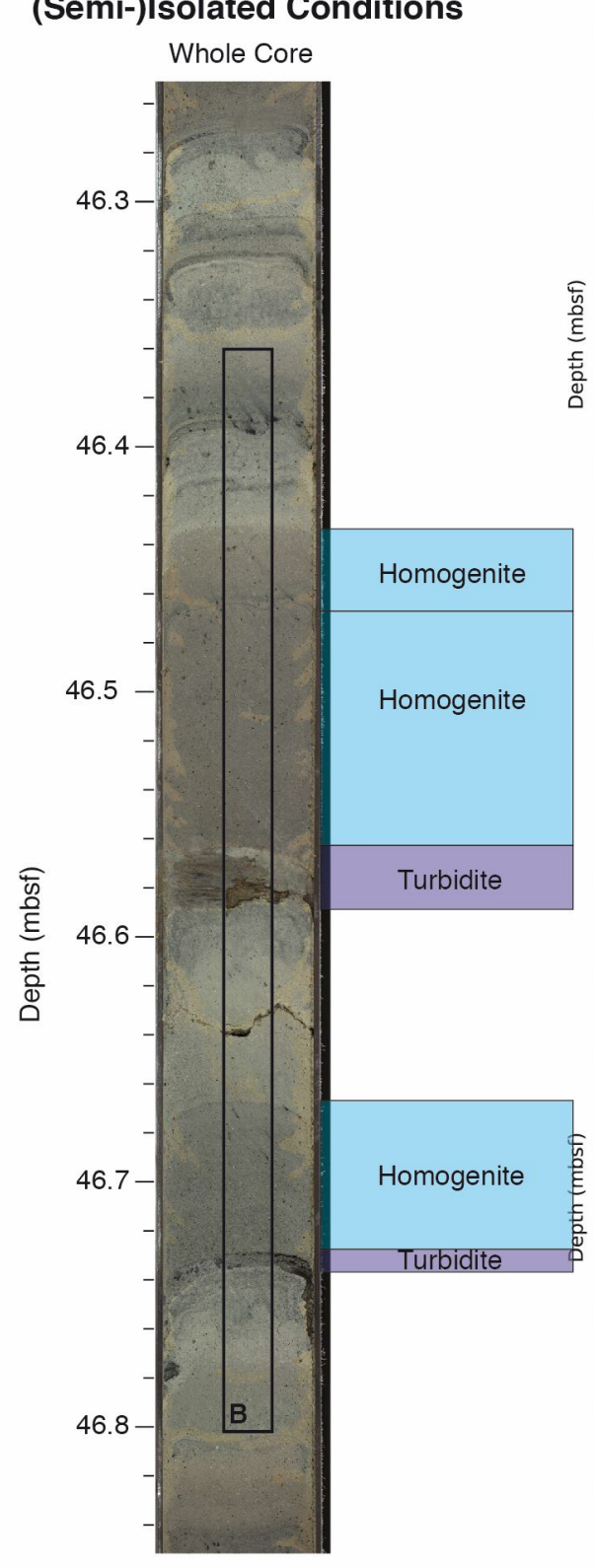

B)

Changes in biogenic/detrital origin

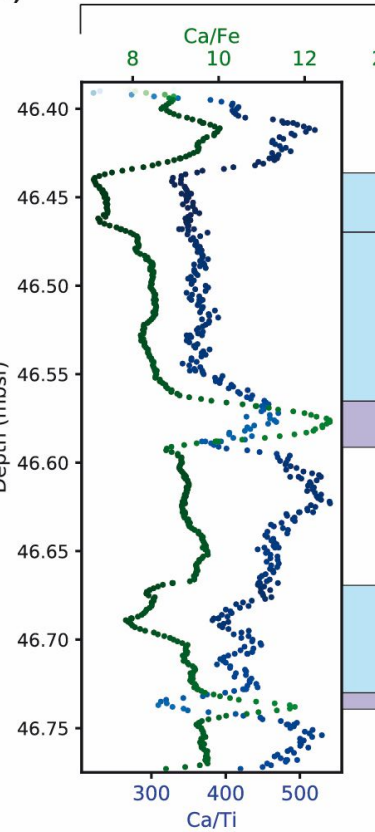

$\begin{array}{lll} & \text { Ca/Sr } & \\ 30.0 & 32.5\end{array}$

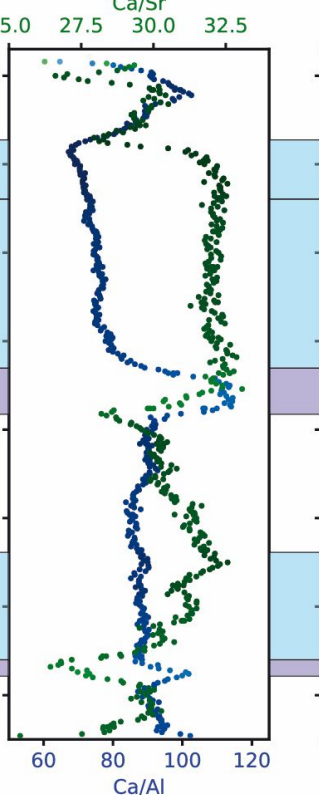

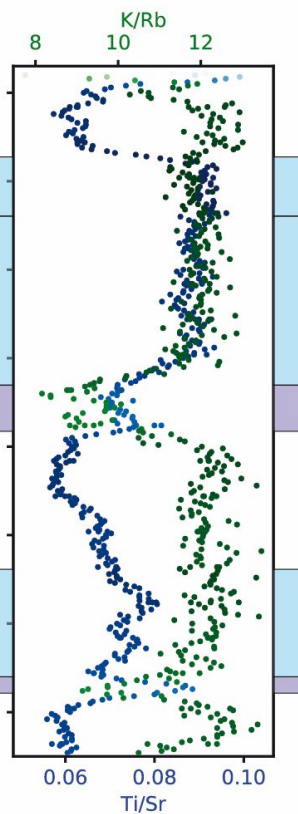

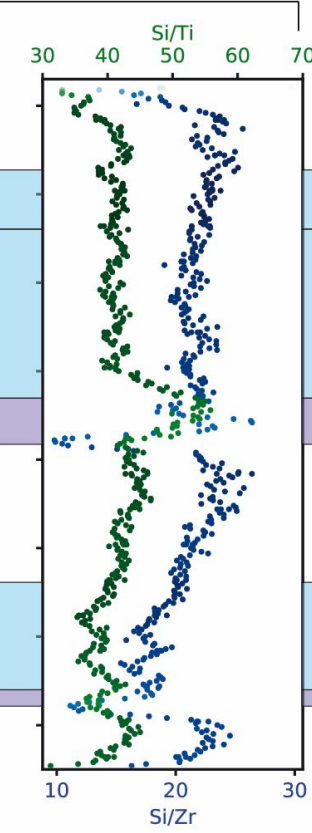

Productivity/post-depositional alteration

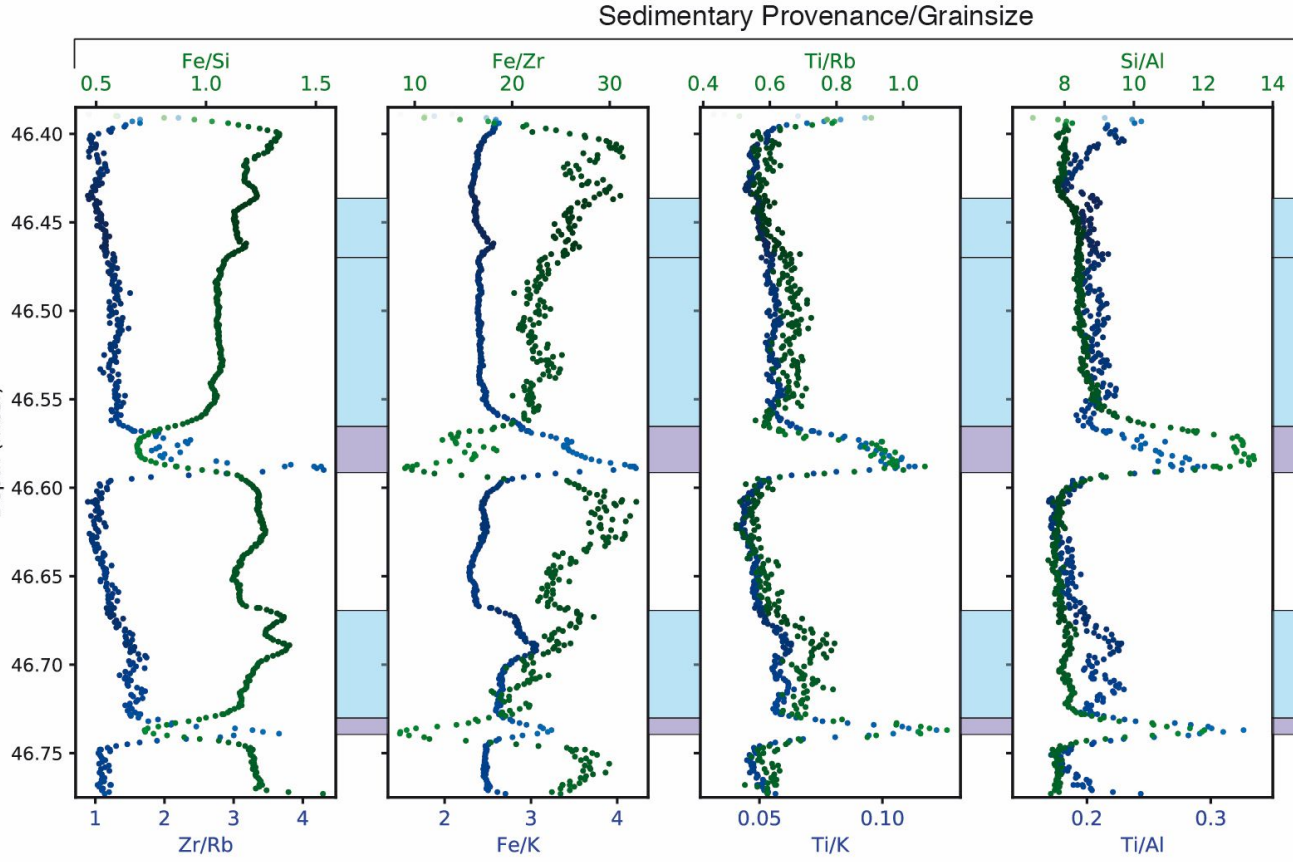

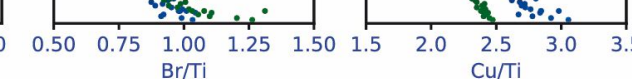

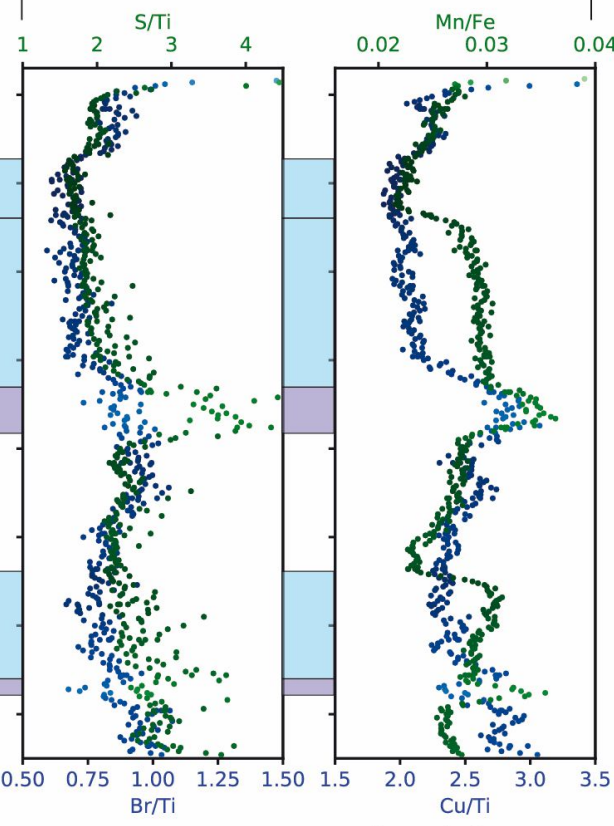

$\cdot 0.04$

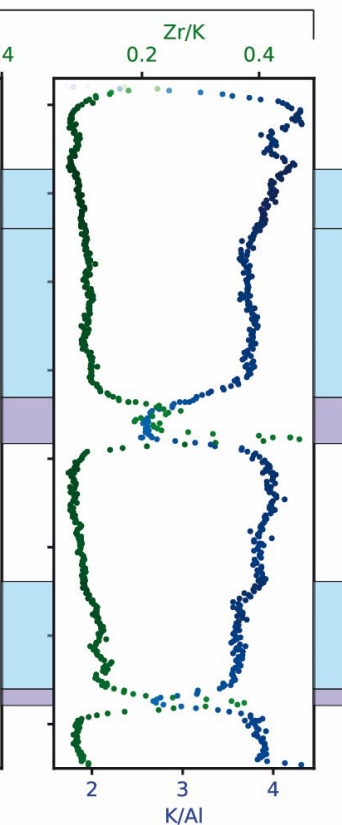

S/CI 0.050
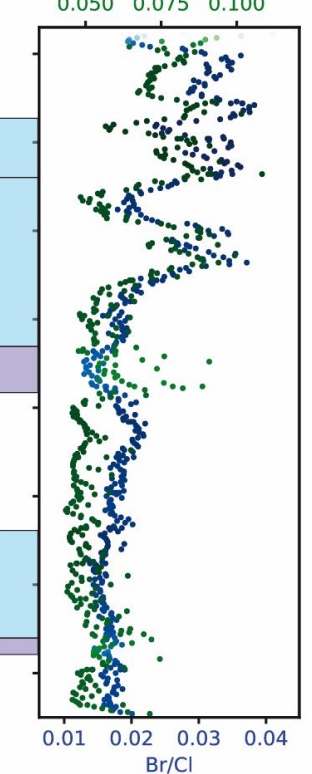
A) M0079A-15P-1

U-Channel 8

(Semi-)Isolated Conditions

Whole Core

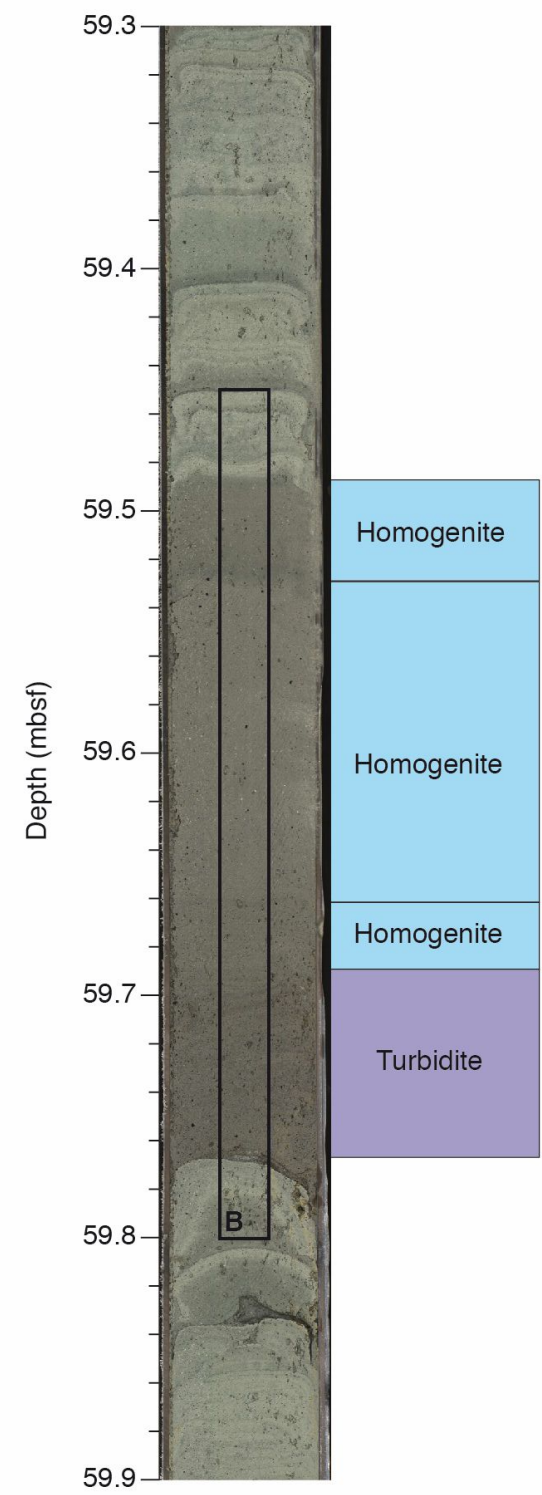

B)

Changes in biogenic/detrital origin
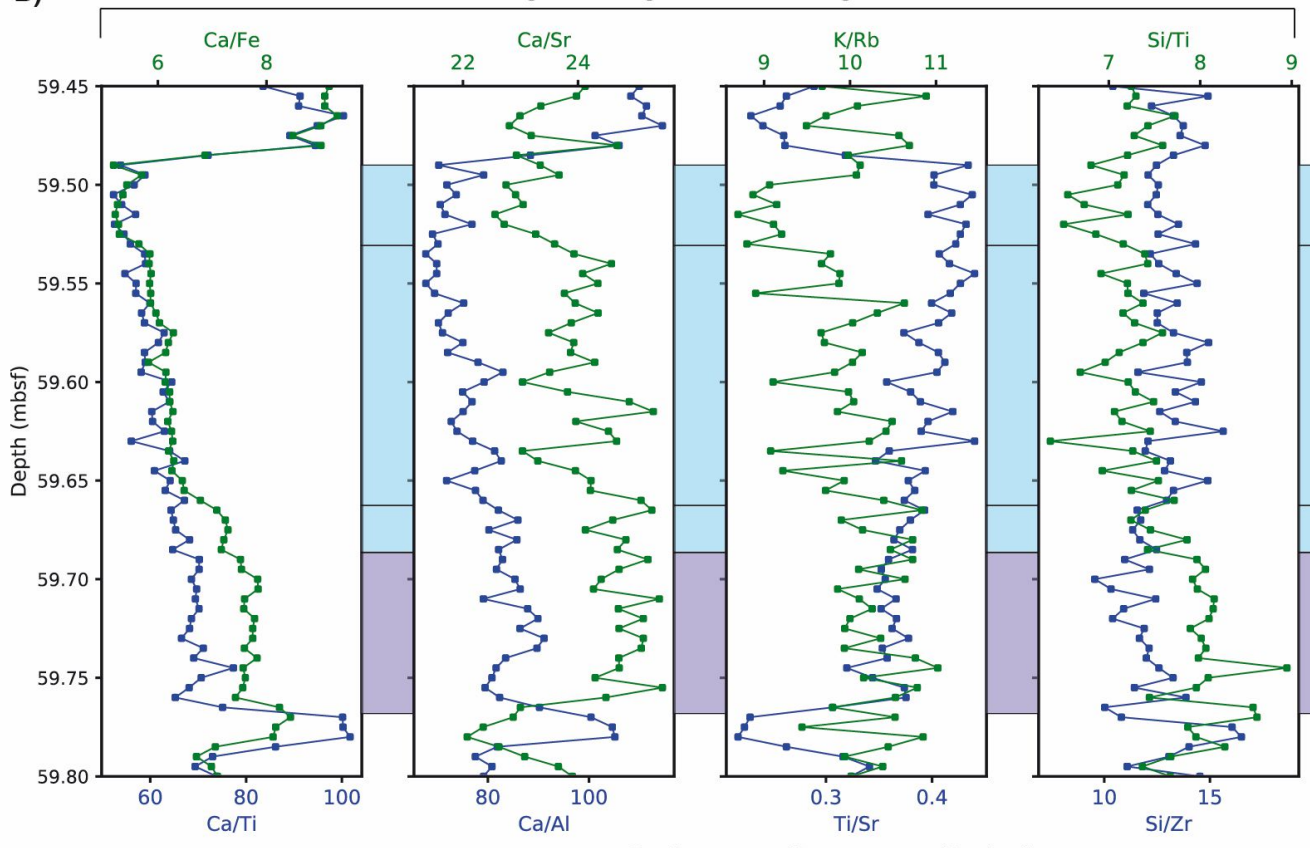

Productivity/post-depositional alteration
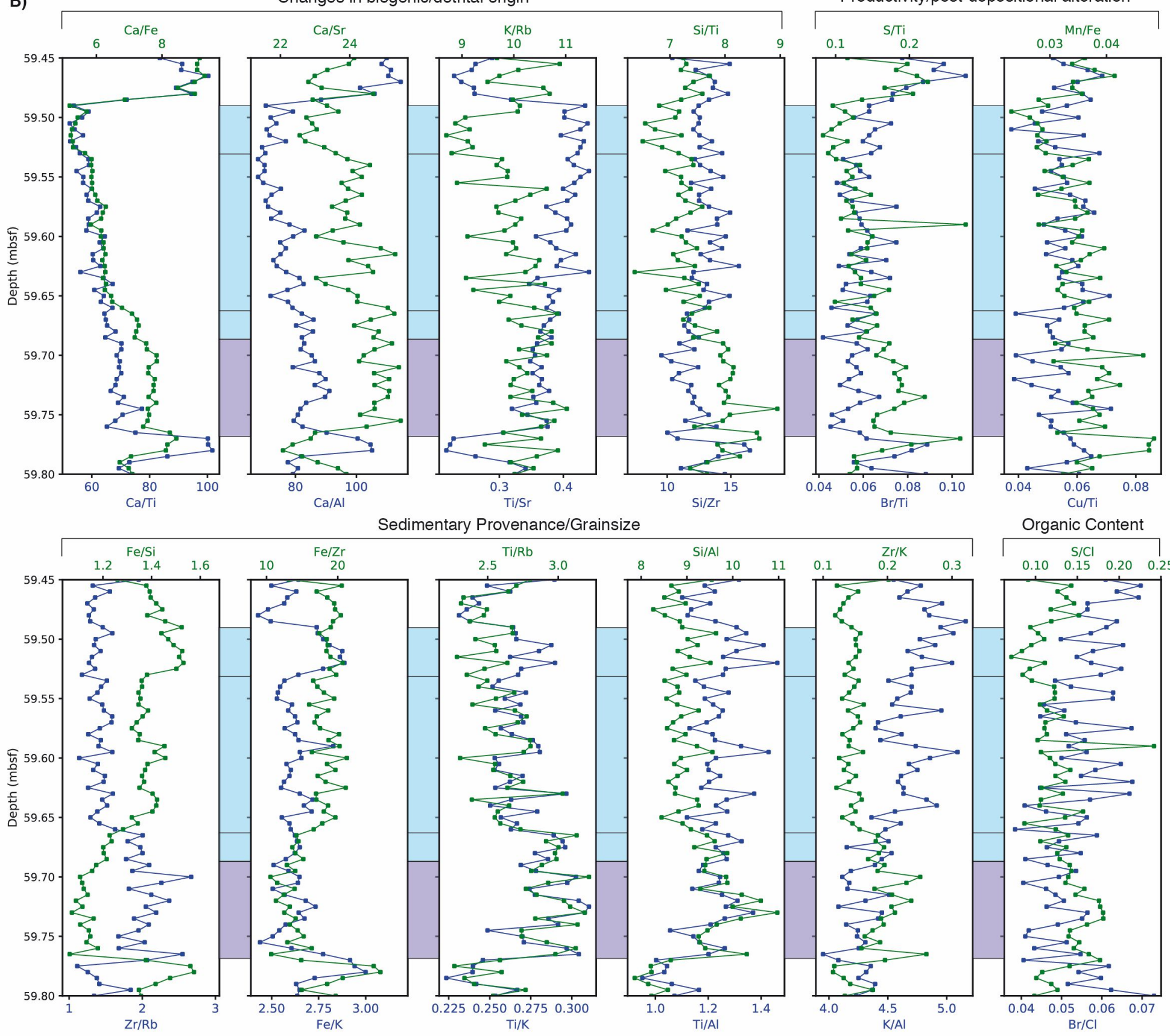
M0078B-2P-1

U-Channel 1 Marine Conditions

Whole Core

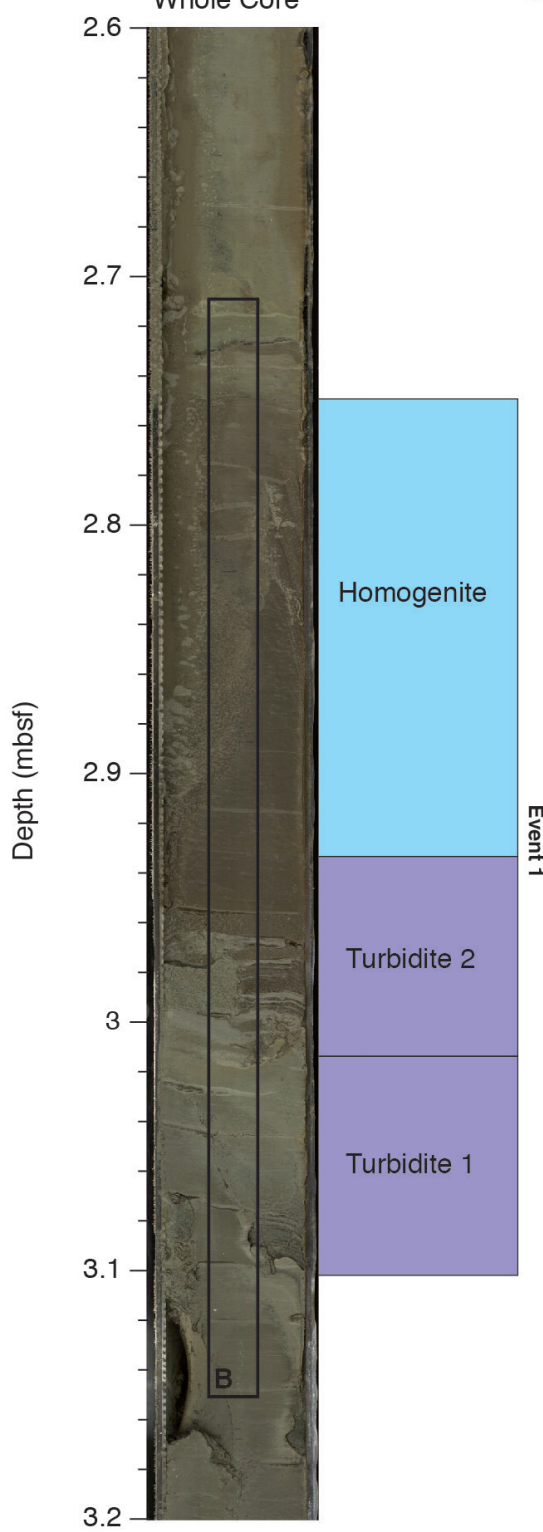

Supplementary Figure 4: Overview of U-Channels 1, 2, 3, 5, 7 and 8 (7 pages) a) Whole core overviews including position of u-channel and different events. b) Low Resolution (LR) X-Ray image and measurements, including grainsize, grainshape, magnetic susceptibility, Anisotropy of Magnetic Susceptibility (AMS) and the same X-Ray Fluorescence (XRF) ratios as in Figs. 5 and 6 c) and d) For U-Channels 2 and 8: zoom-ins of intervals scanned with High Resolution

Microtomography, showing Low Resolution (LR) and High Resolution (HR) X-Ray images and measurements of area, orientation, and aspect of visible grains in HR $X$-Ray, average pixel value in HR X-Ray, and the same XRF ratios as in $b$.

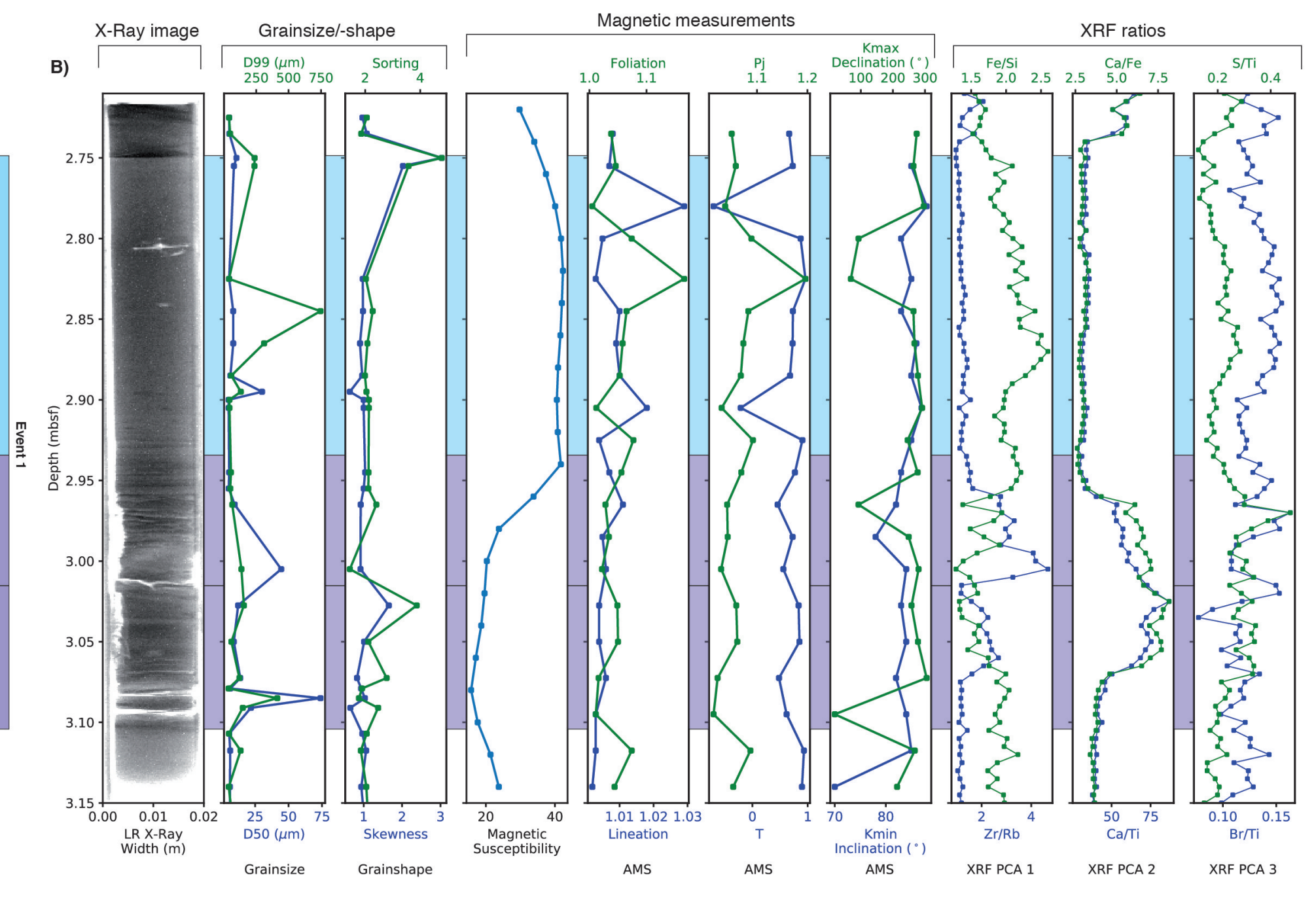


0078B-7P-2

U-Channel 2

Marine Conditions

Whole Core

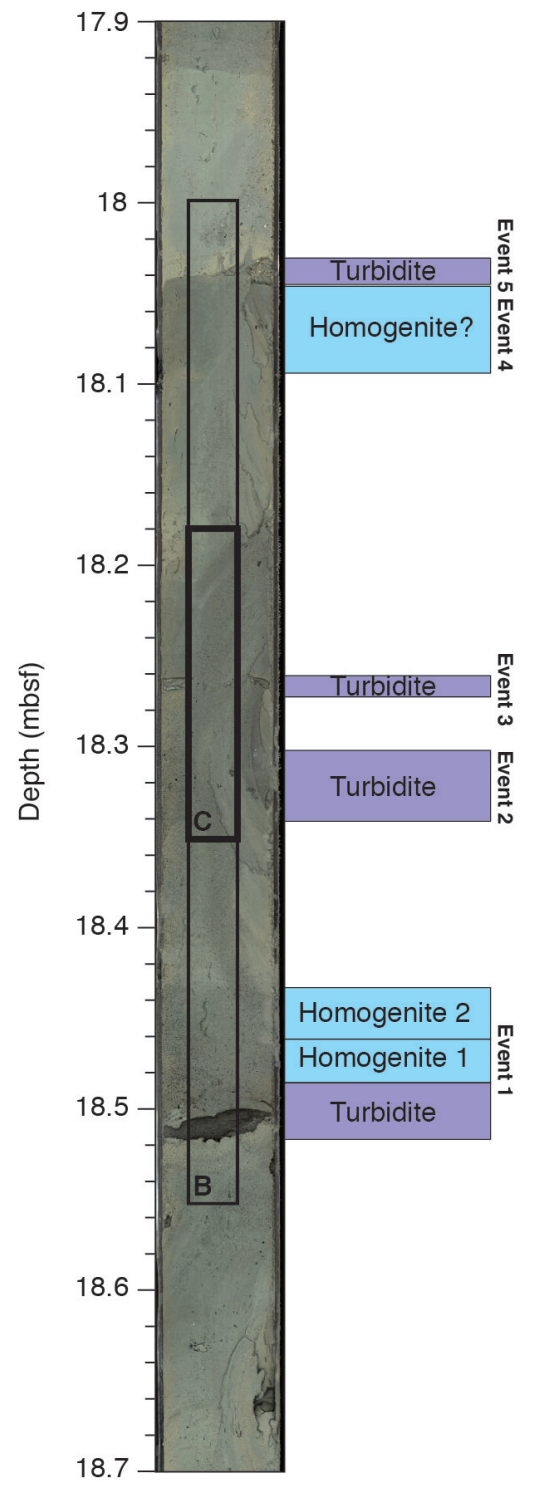

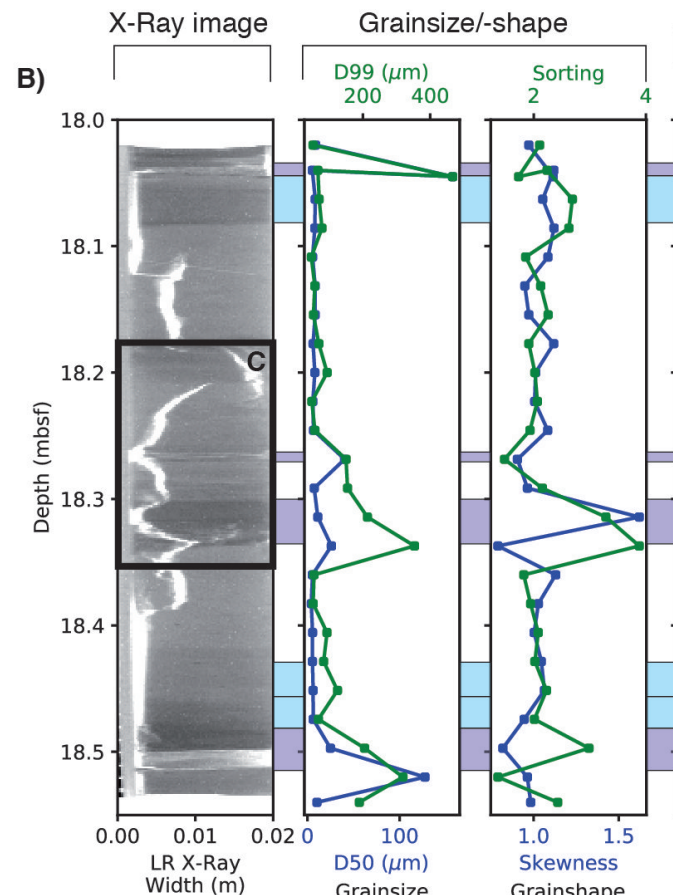

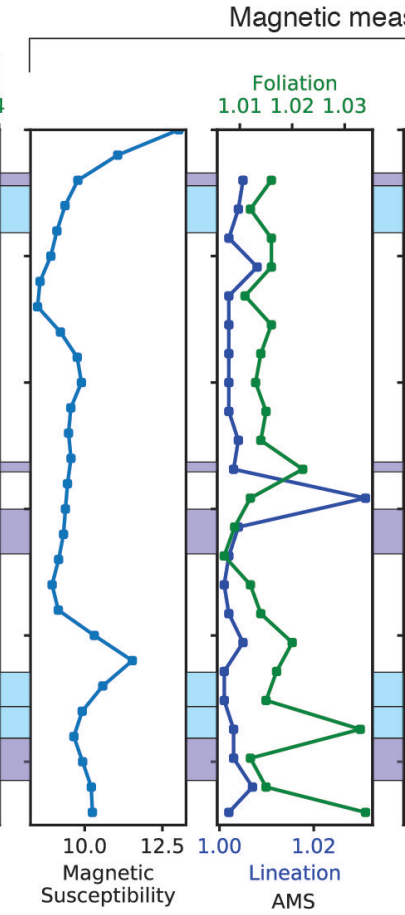

ic measurements

C)

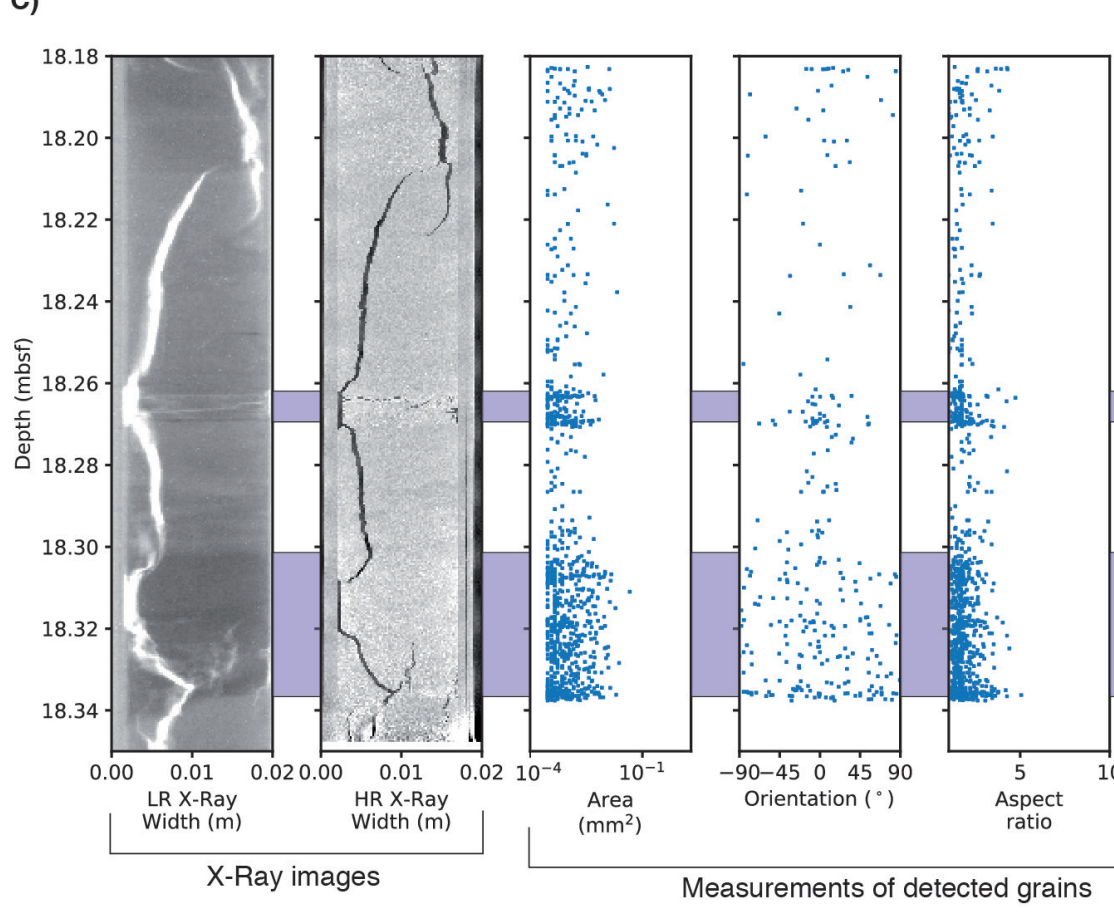

XRF ratios

$\mathrm{Ca} / \mathrm{Fe}{ }_{15} \mathrm{~S} / \mathrm{Ti}$

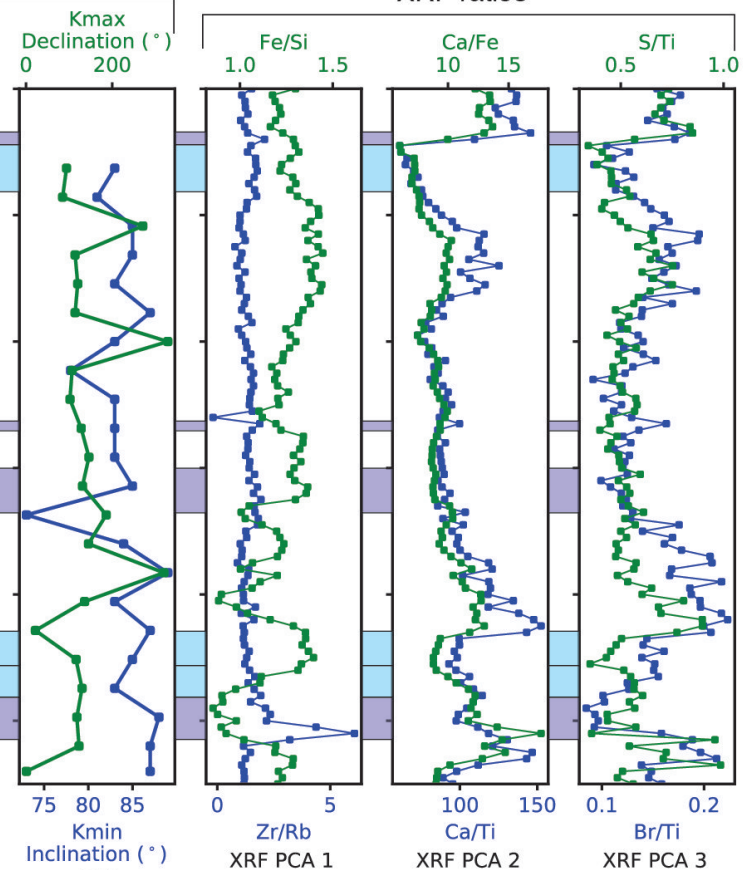
XRF PCA 2 XRF PCA

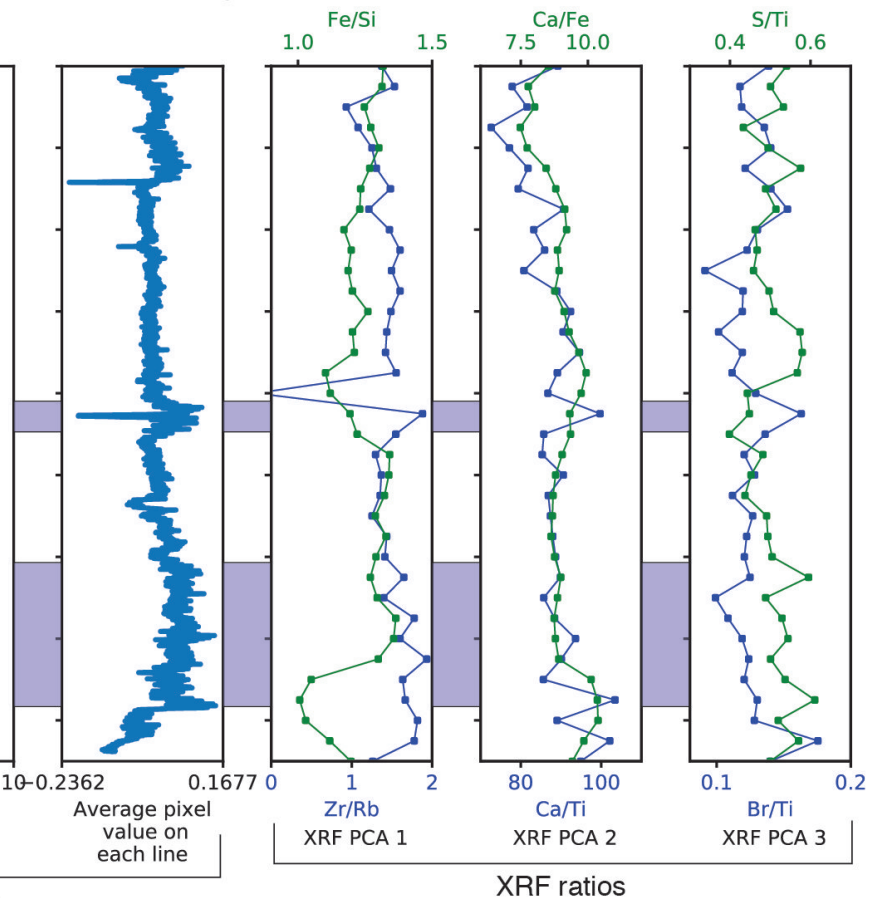


M0078B-8P-3

U-Channel 3

(Semi-)Isolated Conditions

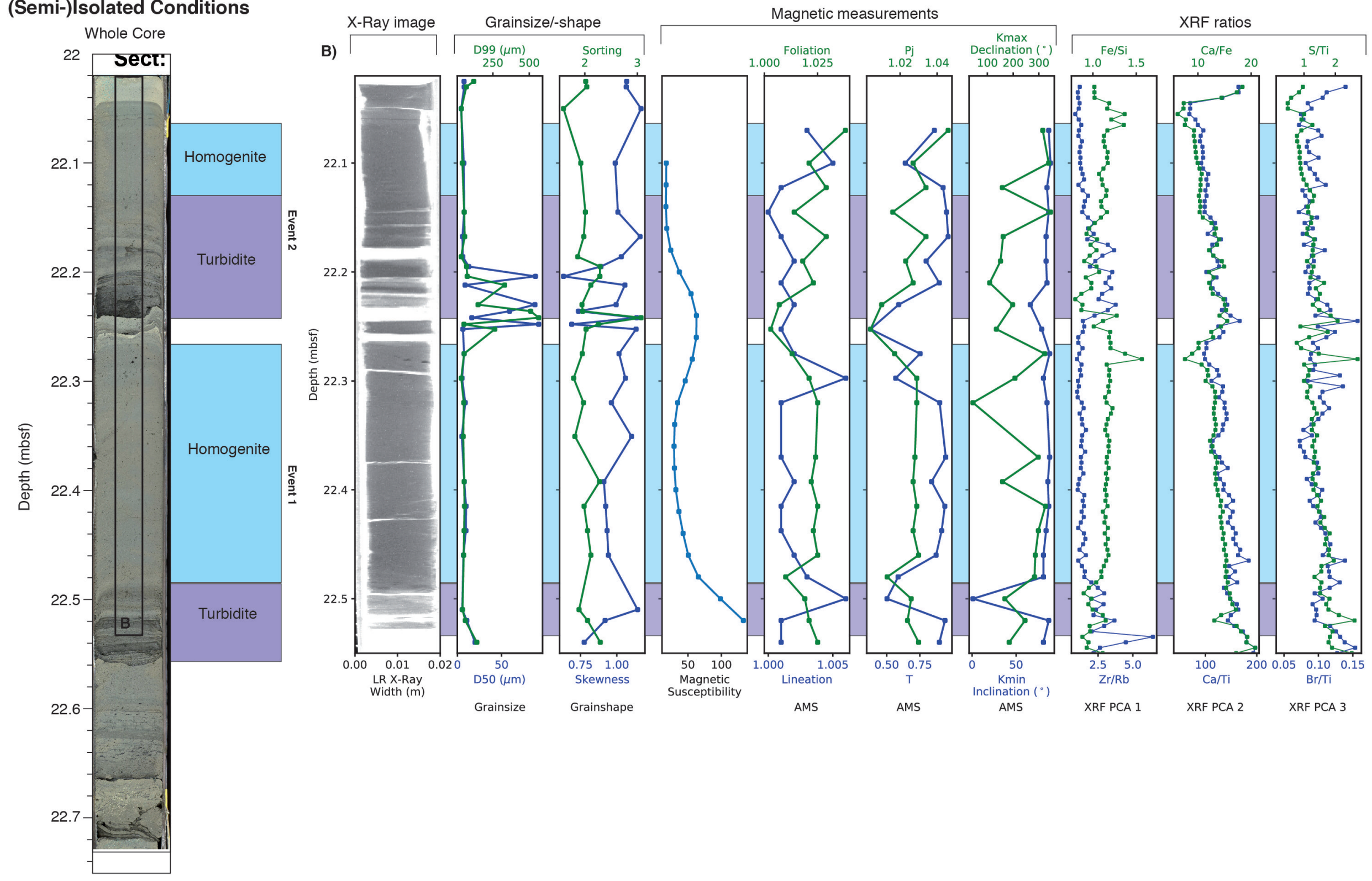



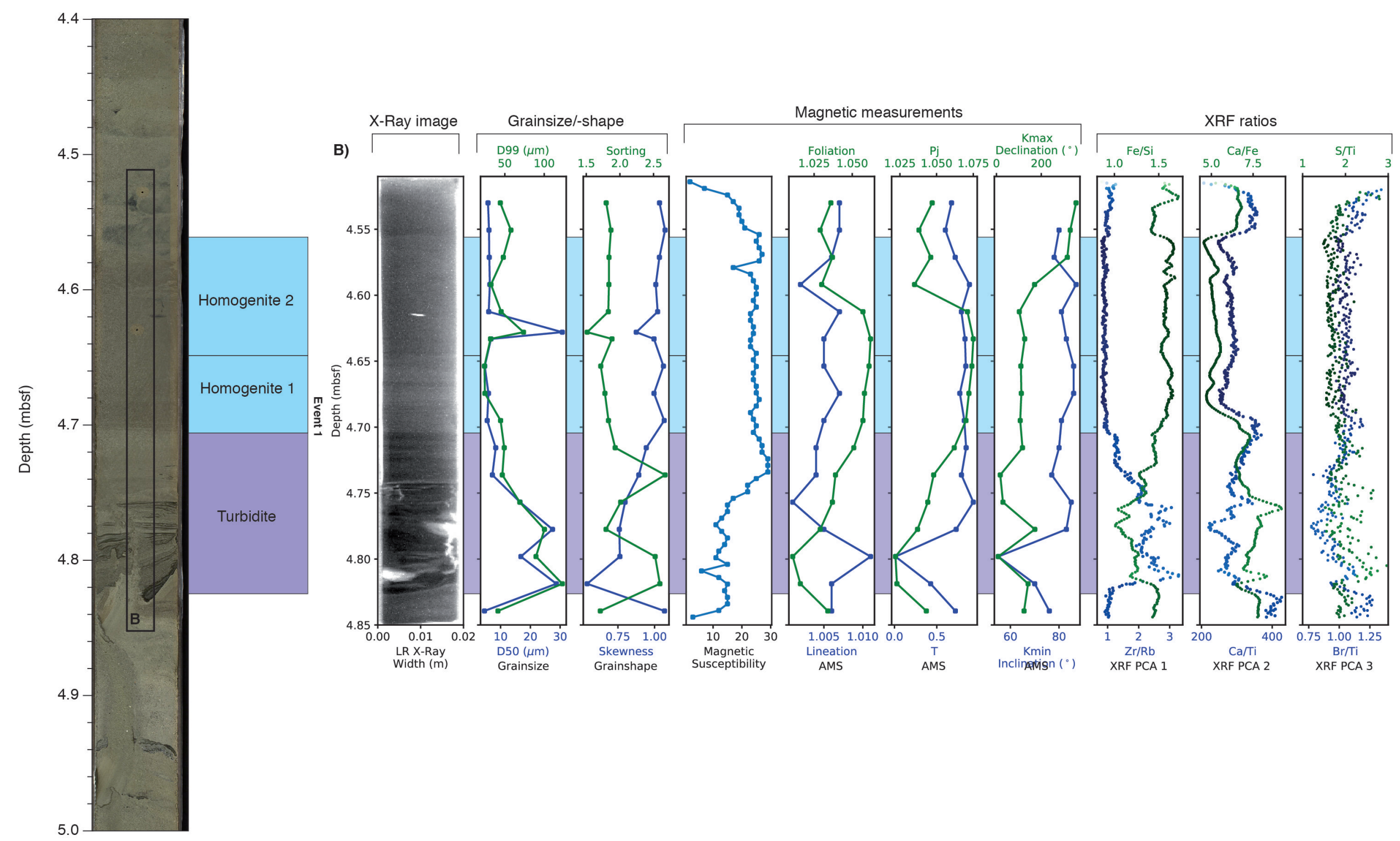
M0079A-12P-3

U-Channel 7

(Semi-)Isolated Conditions

Whole Core
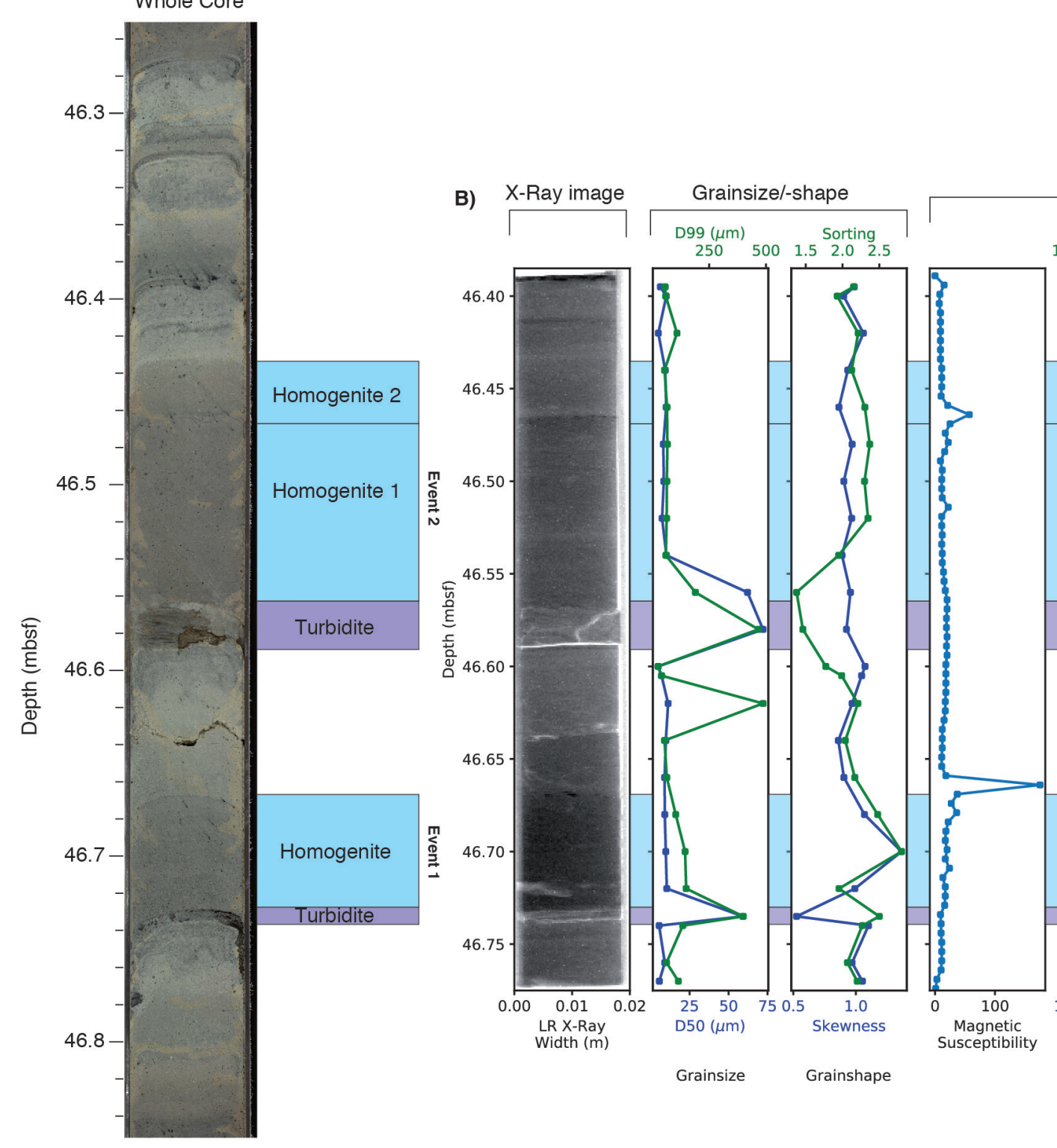

Magnetic measurements
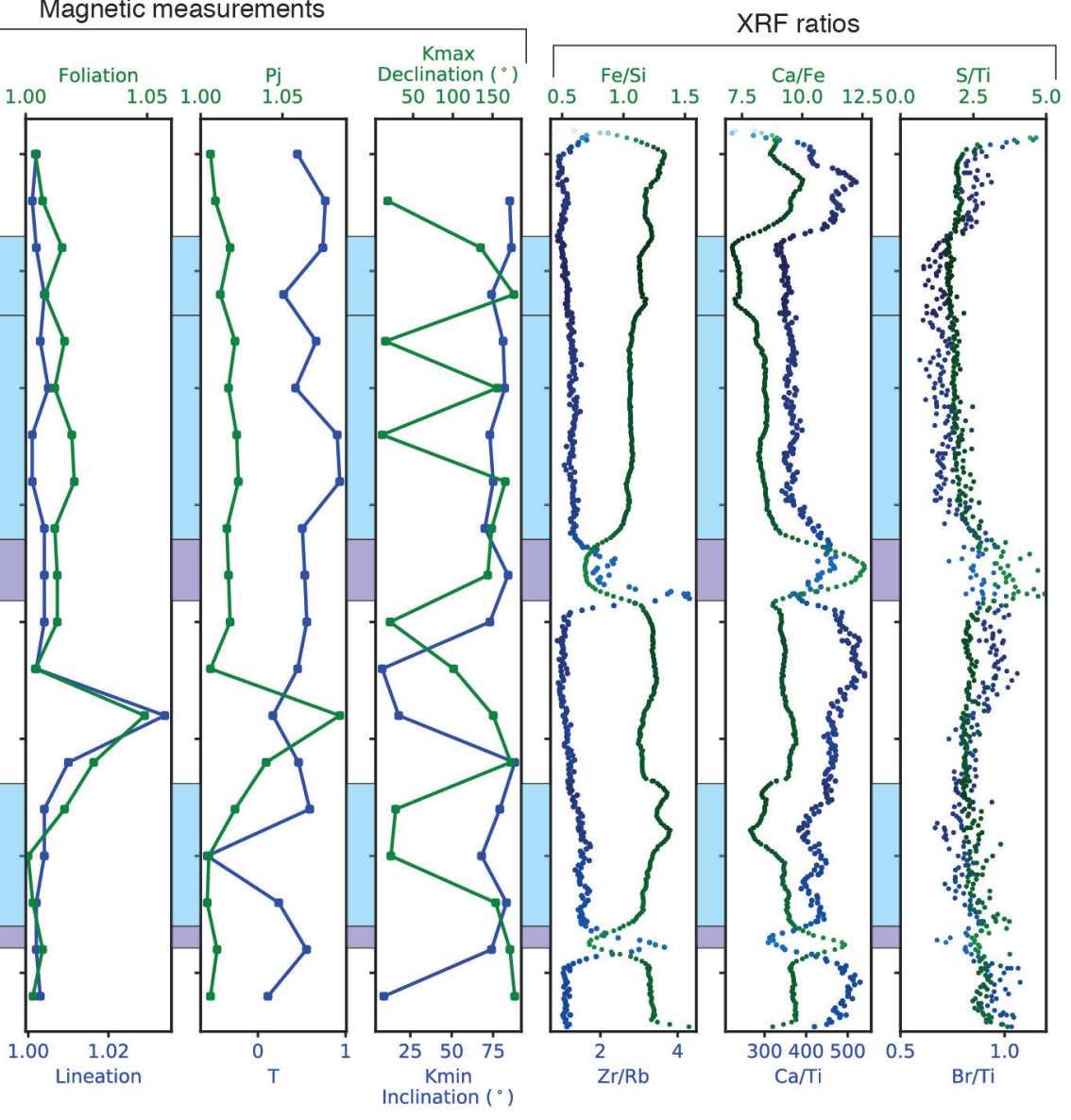

$\begin{array}{ccc}\mathrm{Ca} / \mathrm{Fe} & \\ 7.5 \quad 10.0 & 12.50 .0\end{array}$

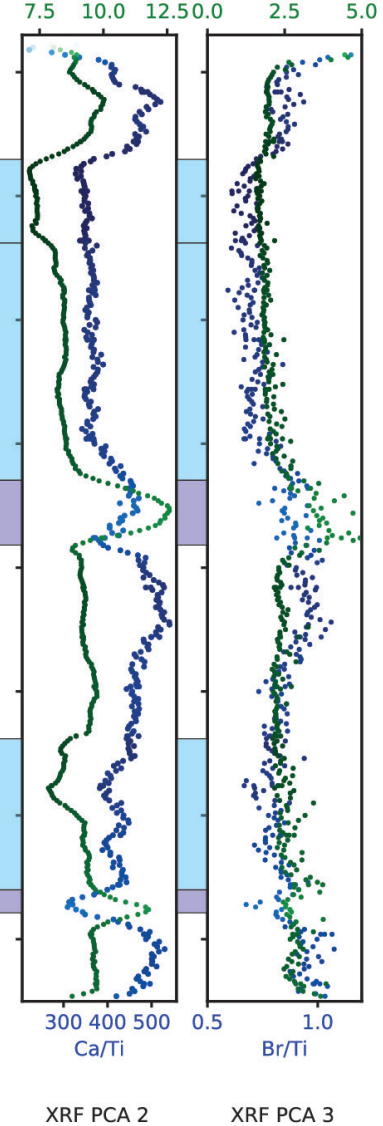


A) M0079A-15P-1

U-Channel 8

(Semi-)Isolated Conditions

Whole Core

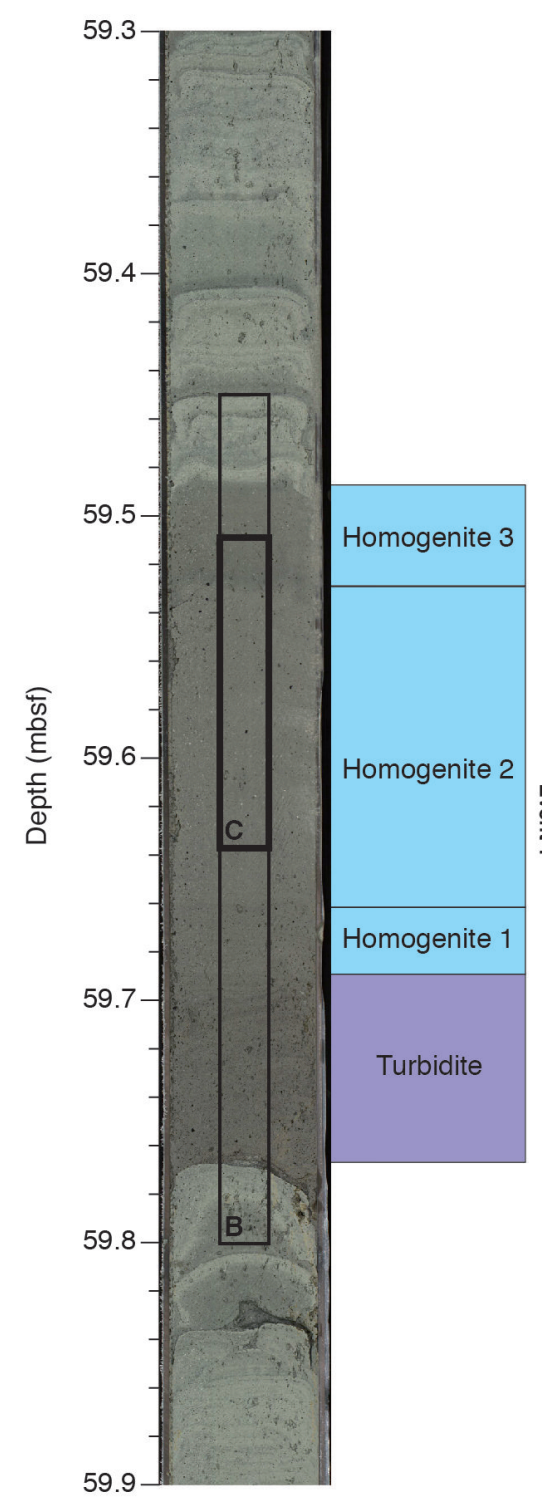

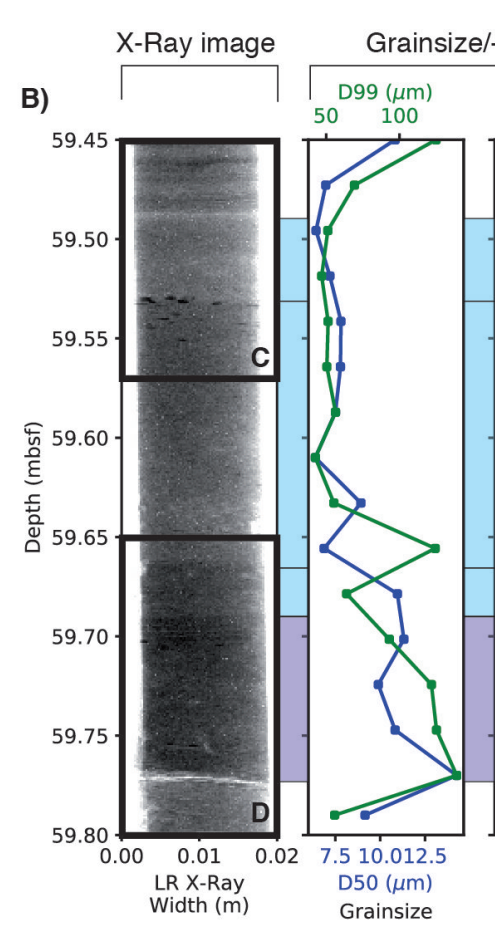

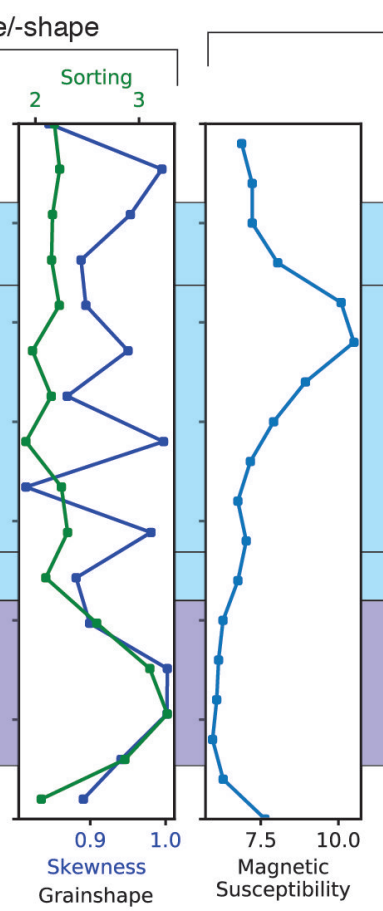

C)
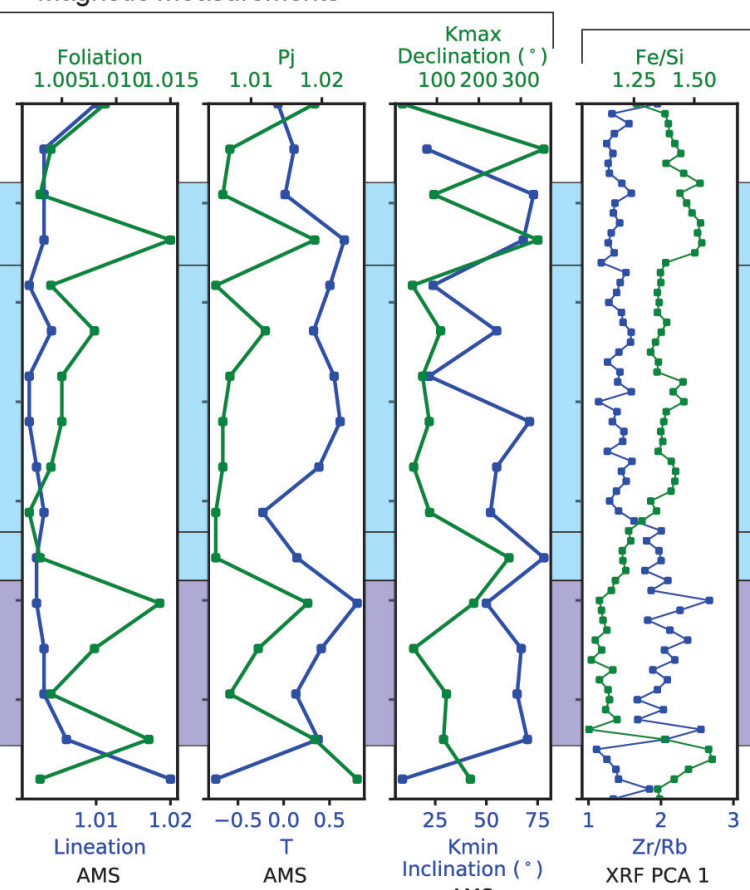

XRF ratios
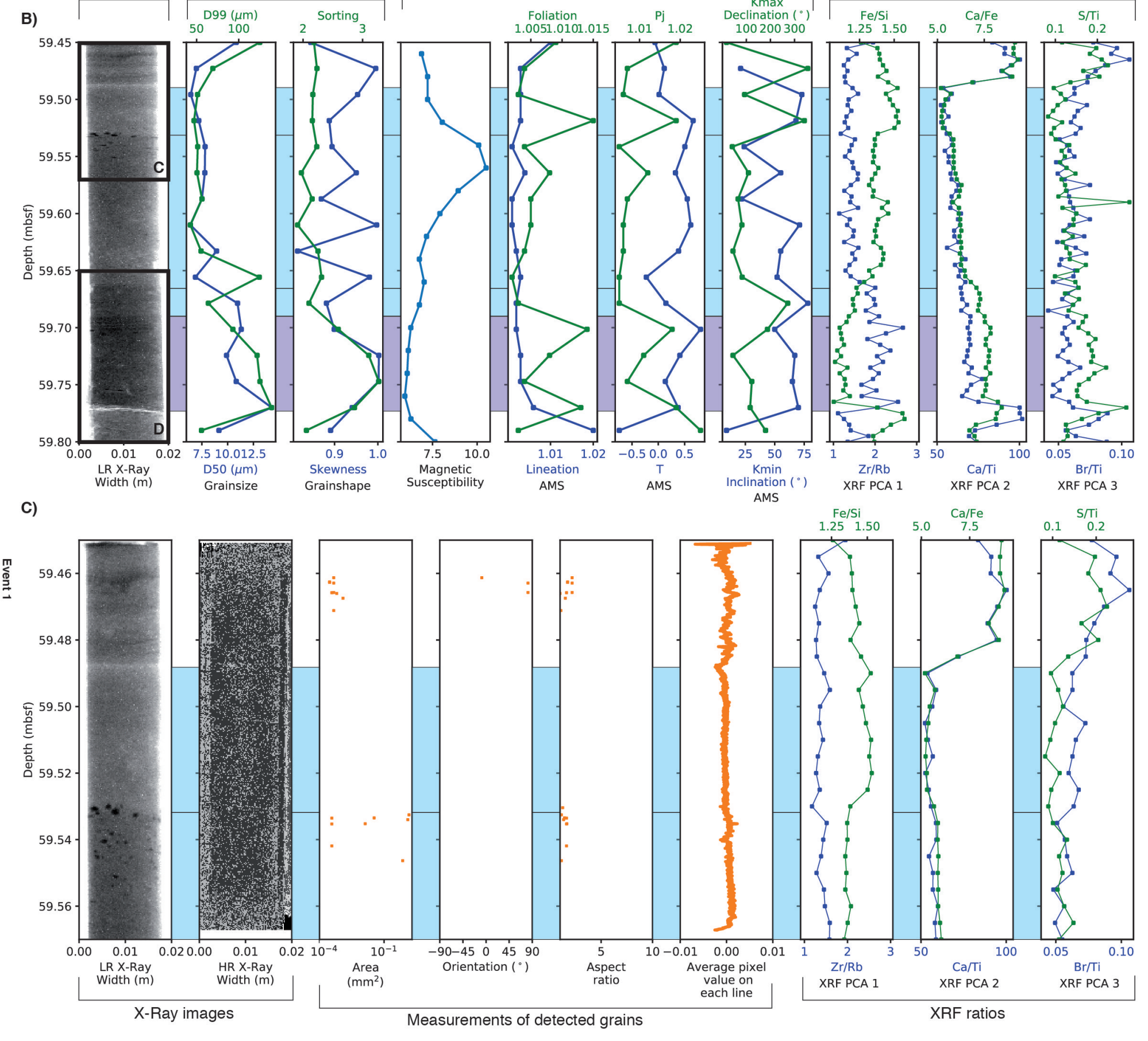


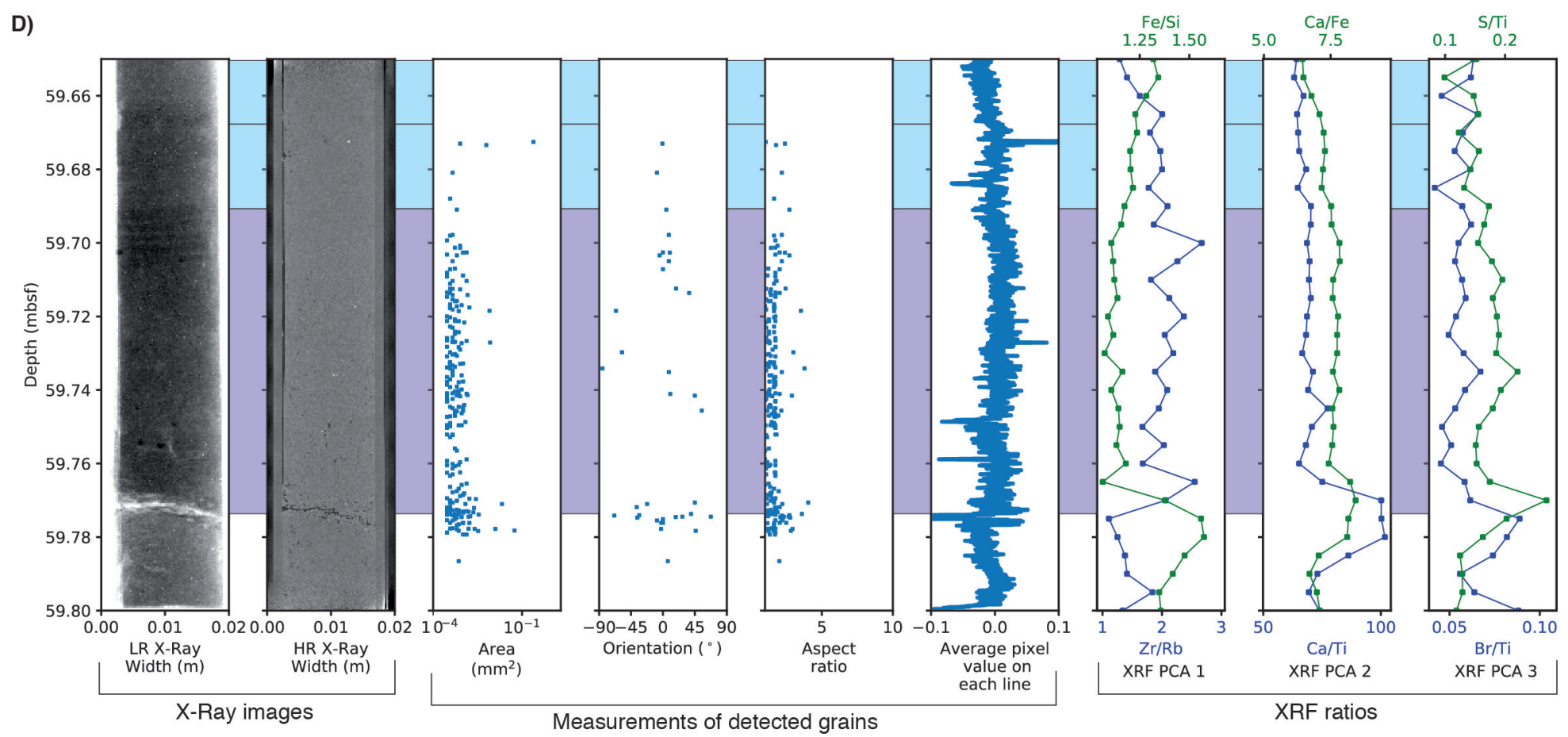


A)
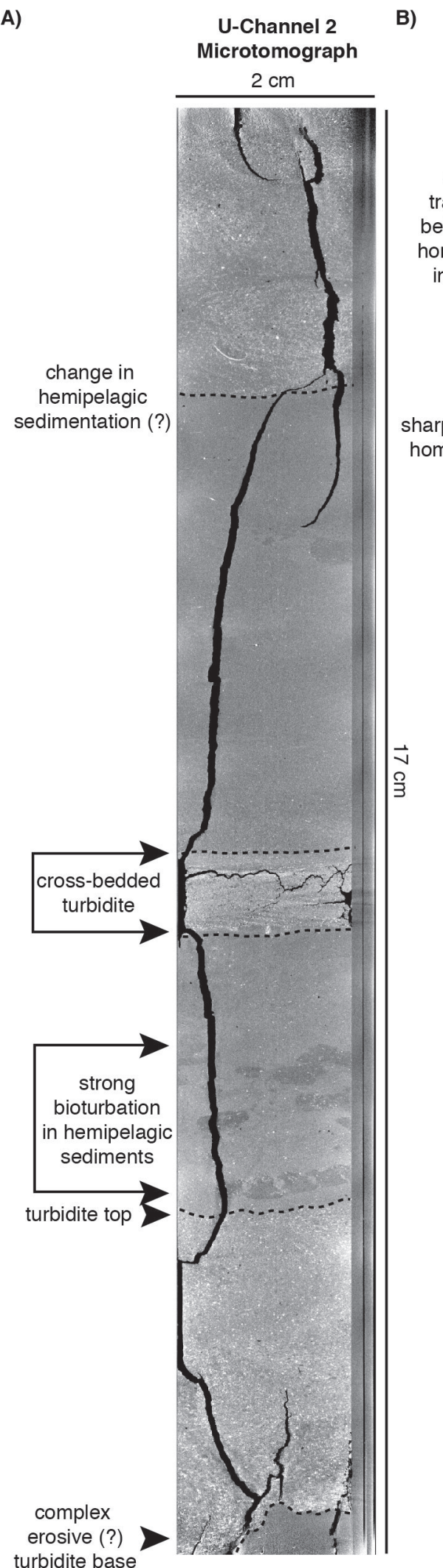

C)

U-Channel 8 Bottom Microtomograph $2 \mathrm{~cm}$

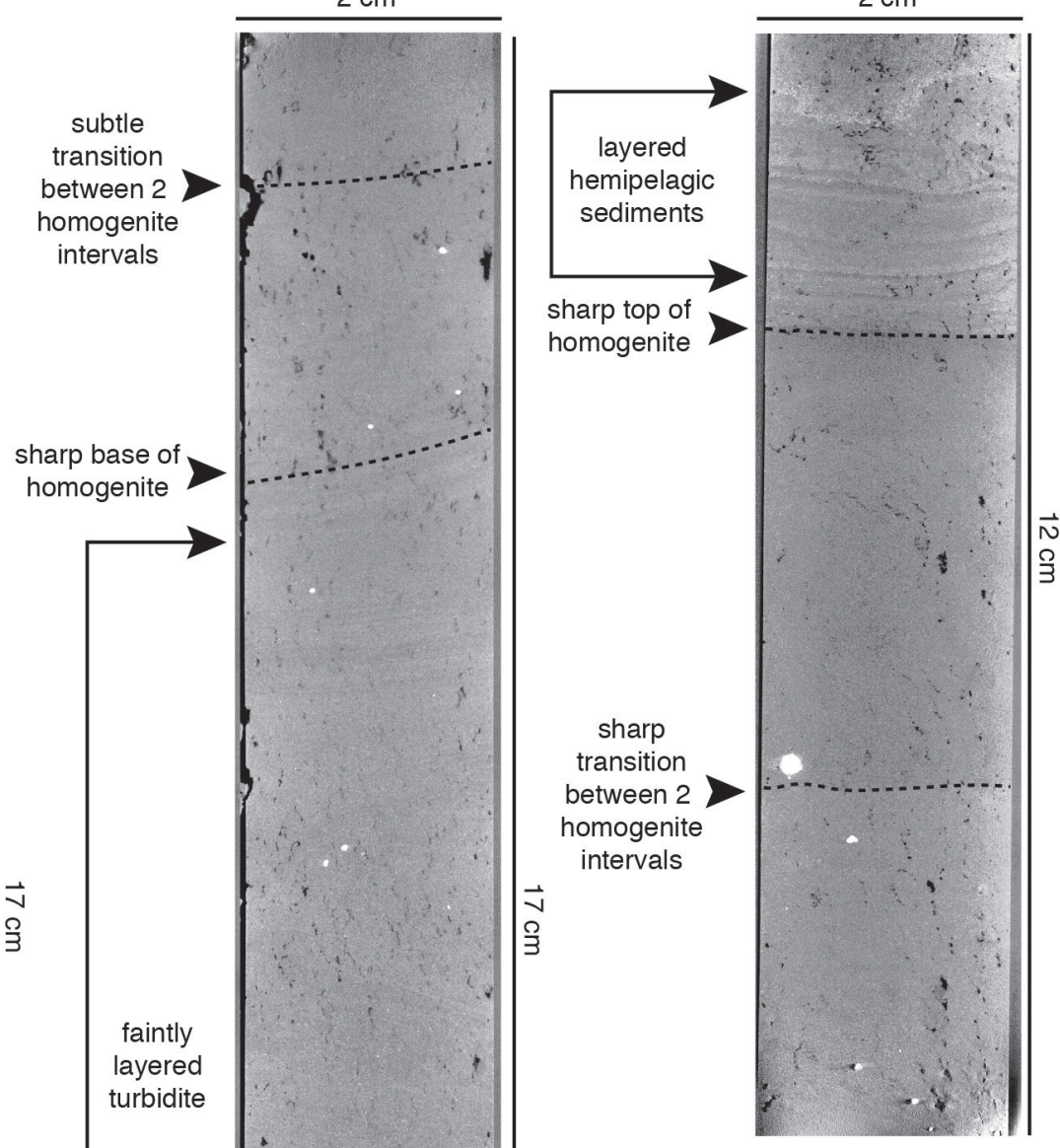

Supplementary Figure 5: X-Ray Microtomography examples for U-Channels 2 and 8 . See positions in Sup. Fig. 3 a) 2D image of sedimentary events in U-Channel 2 b) $2 \mathrm{D}$ image of bottom of U-Channel 8 c) $2 \mathrm{D}$ images of top of U-Channel 8. 
Supplementary Table 1: Overview of sedimentary events in U-Channels. Describing observations on grainsize/-shape, (anisotropy of) magnetic susceptibility, X-Ray Fluorescence ratios, X-Ray images and an overall interpretation of the sedimentary event in relation to the proposed types (Fig. 2)

\begin{tabular}{|c|c|c|c|c|c|c|c|}
\hline U-Channel & Event & $\begin{array}{l}\text { Size } \\
(\mathrm{mm})\end{array}$ & Grainsize/-shape & AMS/Mag. Sus & XRF & X-ray tomography & Interpretation \\
\hline UC-1 (mar) & $\begin{array}{c}1 \\
(\text { Tu1+ } \\
\text { Tu2+ } \\
\mathrm{Hm})\end{array}$ & 352 & $\begin{array}{l}\text { Two major fining } \\
\text { upwards pulses in Tu, } \\
\text { similar grainsize } \mathrm{Hm} \\
\text { and hemipelagic } \\
\text { deposits }\end{array}$ & $\begin{array}{l}\text { Higher Magnetic } \\
\text { Susceptibility, average } \\
\text { AMS foliation and } \\
\text { corrected anisotropy } \\
\text { degree } \mathrm{Pj} \text { in Hm }\end{array}$ & $\begin{array}{l}\text { Higher } \mathrm{Zr} / \mathrm{Rb} \text { in Tu, especially } \\
\text { Tu2, also higher } \mathrm{Ca} / \mathrm{Ti} \text { and } \mathrm{Ca} / \mathrm{Fe} \\
\text { in Tu's, increasing within Tu1 and } \\
\text { decreasing within Tu2. Low } \\
\mathrm{Ca} / \mathrm{Fe} \text { and } \mathrm{Ca} / \mathrm{Ti} \text { in } \mathrm{Hm}\end{array}$ & $\begin{array}{l}\text { Low-resolution only. Irregular Tu } \\
\text { base, clear layering within Tu's. } \\
\text { Sharp boundary between Tu and } \\
\mathrm{Hm} \text {, faint layering in lowermost } \\
\text { part of Hm. Sharp boundary Hm } \\
\text { and overlying hemipelagite. }\end{array}$ & $\begin{array}{l}\text { Complex TuHm sedimentary } \\
\text { event with multiple turbiditic } \\
\text { pulses. Possibly of seismic origin }\end{array}$ \\
\hline \multirow[t]{5}{*}{ UC-2 (mar) } & $\begin{array}{l}1 \text { (Tu+ } \\
\mathrm{Hm} 1+ \\
\mathrm{Hm} 2)\end{array}$ & 80 & $\begin{array}{l}\text { Fining upwards Tu, too } \\
\text { small event for details }\end{array}$ & $\begin{array}{l}\text { Higher Magnetic } \\
\text { Susceptibility, average } \\
\text { AMS foliation and } \\
\text { corrected anisotropy } \\
\text { degree } \mathrm{Pj} \text { in } \mathrm{Hm}\end{array}$ & $\begin{array}{l}\text { Higher } \mathrm{Zr} / \mathrm{Rb} \text { in } \mathrm{Tu} \text {, lower } \mathrm{Ca} / \mathrm{Fe} \text {, } \\
\mathrm{Ca} / \mathrm{Ti} \text { and higher } \mathrm{Fe} / \mathrm{Si} \text { in } \mathrm{Hm} \text { 's, } \\
\text { especially } \mathrm{Hm} 2 . \mathrm{S} / \mathrm{Ti} \text { and } \mathrm{Br} / \mathrm{Ti} \\
\text { low in both } \mathrm{Tu} \text { and } \mathrm{Hm}\end{array}$ & $\begin{array}{l}\text { Sharp but very irregular Tu base, } \\
\text { sharp transitions from Tu to } \mathrm{Hm} 1 \text {, } \\
\mathrm{Hm} 1 \text { to } \mathrm{Hm} 2 \text { and } \mathrm{Hm} 2 \text { to - } \\
\text { overlying hemipelagite }\end{array}$ & $\begin{array}{l}\text { Complex TuHm sedimentary } \\
\text { event with two Hm settling } \\
\text { phases, possibly of seismic origin }\end{array}$ \\
\hline & $2(\mathrm{Tu})$ & 40 & $\begin{array}{l}\text { Fining upwards Tu, too } \\
\text { small event for details }\end{array}$ & $\begin{array}{l}\text { Low AMS foliation and } \\
\text { corrected anisotropy } \\
\text { degree } \mathrm{Pj}\end{array}$ & $\begin{array}{l}\text { Strong increase in } \mathrm{Fe} / \mathrm{Si} \text { at base } \\
\text { of } \mathrm{Tu} \text {, gradual decrease in } \mathrm{Ca} / \mathrm{Ti} \\
\text { and } \mathrm{Ca} / \mathrm{Fe} \text { upwards }\end{array}$ & $\begin{array}{l}\text { Irregular, erosive Tu base, no } \\
\text { clear layering within Tu and } \\
\text { sharp top of Tu }\end{array}$ & $\begin{array}{l}\text { Small 'classic' turbidite of } \\
\text { unknown origin }\end{array}$ \\
\hline & $3(\mathrm{Tu})$ & 12 & $\begin{array}{l}\text { Relatively high } \\
\text { grainsize compared to } \\
\text { hemipelagic deposits }\end{array}$ & High AMS foliation & Small peak in $\mathrm{Br} / \mathrm{Ti}$ and $\mathrm{Ca} / \mathrm{Ti}$ & $\begin{array}{l}\text { Relatively smooth Tu base, } \\
\text { cross-bedded layering within Tu }\end{array}$ & $\begin{array}{l}\text { Small 'classic' turbidite of } \\
\text { unknown origin }\end{array}$ \\
\hline & $4(\mathrm{Hm})$ & 50 & $\begin{array}{l}\text { Similar grainsize to } \\
\text { hemipelagic deposits }\end{array}$ & No clear trends & Low $\mathrm{Ca} / \mathrm{Fe}$ and $\mathrm{Ca} / \mathrm{Ti}$ ratios & $\begin{array}{l}\text { Sharp transitions at both bottom } \\
\text { and top, with possibly a thin, } \\
\text { darker (coarser?) layer at the } \\
\text { bottom of } \mathrm{Hm}\end{array}$ & $\begin{array}{l}\text { Homogenite with possibly a small } \\
\text { silt turbidite at base. Cut off at the } \\
\text { top by overlying turbidite. } \\
\text { Possibly of seismic origin }\end{array}$ \\
\hline & $5(\mathrm{Tu})$ & 14 & $\begin{array}{l}\text { Relatively high } \\
\text { grainsize compared to } \\
\text { hemipelagic deposits }\end{array}$ & No clear trends & $\begin{array}{l}\text { Sharp changes in } \mathrm{Ca} / \mathrm{Fe}, \mathrm{Ca} / \mathrm{Ti} \text {, } \\
\mathrm{S} / \mathrm{Ti} \text { and } \mathrm{Br} / \mathrm{Ti} \text { ratios between } \\
\text { underlying and overlying deposits }\end{array}$ & $\begin{array}{l}\text { Too thin for observations on low- } \\
\text { resolution X-ray tomography }\end{array}$ & $\begin{array}{l}\text { Small 'classic' turbidite, } \\
\text { associated with a change in } \\
\text { hemipelagic sedimentation, } \\
\text { possibly changing environmental } \\
\text { conditions }\end{array}$ \\
\hline \multirow[t]{2}{*}{ UC-3 (ISI) } & $\begin{array}{c}1(\mathrm{Tu}+ \\
\mathrm{Hm})\end{array}$ & 295 & $\begin{array}{l}\text { Fining upwards Tu, } \\
\text { uniform grainsize } \\
\text { throughout } \mathrm{Hm}\end{array}$ & $\begin{array}{l}\text { Peaks in Magnetic } \\
\text { Susceptibility and AMS } \\
\text { lineation at both Tu and } \\
\text { top of } \mathrm{Hm}\end{array}$ & $\begin{array}{l}\text { Peak in } \mathrm{Zr} / \mathrm{Rb} \text { at base of } \mathrm{Tu} \text {, } \\
\text { peaks in } \mathrm{Fe} / \mathrm{Si} \text { and } \mathrm{S} / \mathrm{Ti} \text { at top of } \\
\mathrm{Hm} . \mathrm{Ca} / \mathrm{Ti} \text { and } \mathrm{Ca} / \mathrm{Fe} \text { gradually } \\
\text { decreasing upwards in Tu and } \\
\mathrm{Hm}\end{array}$ & $\begin{array}{l}\text { Strong layering within } \mathrm{Tu} \text {, faint } \\
\text { layering in } \mathrm{Hm} \text {. Big grains near } \\
\text { the top of the } \mathrm{Hm} \text {. Sharp limit } \\
\text { between } \mathrm{Tu} \text { and } \mathrm{Hm}\end{array}$ & $\begin{array}{l}\text { TuHm sedimentary event, } \\
\text { possibly of seismic origin. Grains } \\
\text { near top probably result from } \\
\text { post-depositional alteration. }\end{array}$ \\
\hline & $\begin{array}{c}2(\mathrm{Tu}+ \\
\mathrm{Hm})\end{array}$ & 175 & $\begin{array}{l}\text { Strongly fluctuating at } \\
\text { base of Tu, uniformly } \\
\text { small grainsize at top }\end{array}$ & $\begin{array}{l}\text { Within Tu/Hm, general } \\
\text { decrease in in Magnetic } \\
\text { Susceptibility upwards }\end{array}$ & $\begin{array}{l}\text { Peak in } \mathrm{Zr} / \mathrm{Rb} \text { at base of } \mathrm{Tu}, \\
\text { peak in } \mathrm{Fe} / \mathrm{Si} \text { at top of } \mathrm{Hm} . \mathrm{Ca} / \mathrm{Ti} \\
\text { and } \mathrm{Ca} / \mathrm{Fe} \text { irregularly decreasing }\end{array}$ & $\begin{array}{l}\text { Strong layering within Tu, faint } \\
\text { layering in } \mathrm{Hm} \text {. }\end{array}$ & $\begin{array}{l}\text { TuHm sedimentary event, } \\
\text { possibly of seismic origin. }\end{array}$ \\
\hline
\end{tabular}




\begin{tabular}{|c|c|c|c|c|c|c|c|}
\hline & & & of $\mathrm{Tu}$ and $\mathrm{Hm}$ & $\begin{array}{l}\text { and increase in } \mathrm{AMS} \\
\text { foliation, lineation, } \mathrm{Pj} \\
\text { and } \mathrm{T}\end{array}$ & $\begin{array}{l}\text { upwards in Tu and gradually } \\
\text { decreasing upwards in Hm }\end{array}$ & & \\
\hline \multirow[t]{5}{*}{ UC-4 (ISI) } & $1(\mathrm{Tu})$ & 27 & Not sufficient data & Not sufficient data & $\begin{array}{l}\text { Relatively low } \mathrm{Ca} / \mathrm{Fe} \text { and } \mathrm{Ca} / \mathrm{Ti} \text {, } \\
\text { decreasing upwards } \mathrm{Zr} / \mathrm{Rb} \text { and } \\
\text { increasing upwards } \mathrm{Fe} / \mathrm{Si}, \mathrm{Br} / \mathrm{Ti} \\
\text { and } \mathrm{S} / \mathrm{Ti}\end{array}$ & $\begin{array}{l}\text { Sharp transition between Tu and } \\
\text { overlying Hemipelagic sediments }\end{array}$ & $\begin{array}{l}\text { Small 'classic' turbidite of } \\
\text { unknown origin }\end{array}$ \\
\hline & $\begin{array}{l}2 \text { (Tu+ } \\
\mathrm{Hm} 1+ \\
\mathrm{Hm} 2)\end{array}$ & 94 & $\begin{array}{l}\text { Few data, but larger } \\
\text { grainsize in Tu }\end{array}$ & $\begin{array}{l}\text { Higher Magnetic } \\
\text { Susceptibility in Tu, peak } \\
\text { in AMS foliation and } \\
\text { corrected anisotropy } \\
\text { degree Pj in Hm's }\end{array}$ & $\begin{array}{l}\text { Relatively low } \mathrm{Ca} / \mathrm{Fe}, \mathrm{Ca} / \mathrm{Ti}, \mathrm{Br} / \mathrm{Ti} \\
\text { and } \mathrm{S} / \mathrm{Ti} \text { in } \mathrm{Tu} / \mathrm{Hm} \text { event. Two } \\
\text { peaks within } \mathrm{Tu} \text { for } \mathrm{Fe} / \mathrm{Si} \text { and } \\
\mathrm{Zr} / \mathrm{Rb}\end{array}$ & $\begin{array}{l}\text { Microfractured base of Tu, and } \\
\text { several microfractures within } \sim 4 \\
\text { turbiditic pulses near the base, } \\
\text { neat base of } \mathrm{Hm} \text { and sharp } \\
\text { transition to upper } \mathrm{Hm} \text {. Diffuse } \\
\text { (bioturbated) top of } \mathrm{Hm} \text {. }\end{array}$ & $\begin{array}{l}\text { Complex TuHm sedimentary } \\
\text { event of seismic origin. } \\
\text { Microfractures at Tu base and } \\
\text { two settling phases for } \mathrm{Hm} 1 \text { and } \\
\mathrm{Hm} 2\end{array}$ \\
\hline & $\begin{array}{c}3(\mathrm{Tu}+ \\
\mathrm{Hm})\end{array}$ & 25 & Not sufficient data & Not sufficient data & $\begin{array}{l}\text { Gradual decrease in } \mathrm{Zr} / \mathrm{Rb} \text { within } \\
\text { Tu/Hm, sharp increase in } \mathrm{Ca} / \mathrm{Ti} \\
\text { at } \mathrm{Hm} \text {-Hemipelagic transition }\end{array}$ & $\begin{array}{l}\text { Sharp base of Tu and diffuse top } \\
\text { of } \mathrm{Hm} \text {. }\end{array}$ & $\begin{array}{l}\text { TuHm sedimentary event } \\
\text { possibly of seismic origin. }\end{array}$ \\
\hline & $\begin{array}{l}4 \text { (Tu+ } \\
\mathrm{Hm} 1+ \\
\mathrm{Hm} 2)\end{array}$ & 40 & $\begin{array}{l}\text { Few data, but larger } \\
\text { grainsize in Tu }\end{array}$ & $\begin{array}{l}\text { Higher Magnetic } \\
\text { Susceptibility in Tu, peak } \\
\text { in AMS foliation and } \\
\text { corrected anisotropy } \\
\text { degree } \mathrm{Pj} \text { in Hm's }\end{array}$ & $\begin{array}{l}\text { Relatively low } \mathrm{Ca} / \mathrm{Fe}, \mathrm{Ca} / \mathrm{Ti}, \mathrm{Br} / \mathrm{Ti} \\
\text { and } \mathrm{S} / \mathrm{Ti} \text { in } \mathrm{Tu} / \mathrm{Hm} \text { event. } \mathrm{Zr} / \mathrm{Rb} \\
\text { decreasing and } \mathrm{Fe} / \mathrm{Si} \text { increasing } \\
\text { upwards within } \mathrm{Tu} \text {. }\end{array}$ & $\begin{array}{l}\text { Microfractured base of Tu, faint } \\
\text { layering within Tu and a neat } \\
\text { base of } \mathrm{Hm} \text {. Diffuse (bioturbated) } \\
\text { top of } \mathrm{Hm} \text {. }\end{array}$ & $\begin{array}{l}\text { Complex TuHm sedimentary } \\
\text { event of seismic origin. } \\
\text { Microfractures at Tu base and } \\
\text { two settling phases for } \mathrm{Hm} 1 \text { and } \\
\mathrm{Hm} 2\end{array}$ \\
\hline & $5(\mathrm{Tu})$ & 55 & $\begin{array}{l}\text { Few data, but larger } \\
\text { grainsize at base of Tu }\end{array}$ & $\begin{array}{l}\text { Relatively high Magnetic } \\
\text { Susceptibility, peak near } \\
\text { top of Tu. Relatively high } \\
\text { AMS lineation and low } \\
\text { foliation, } T \text { and } P j\end{array}$ & $\begin{array}{l}\text { Overall increase in } \mathrm{Fe} / \mathrm{Si} \text { and } \\
\text { decrease in } \mathrm{Ca} / \mathrm{Ti}, \mathrm{Ca} / \mathrm{Fe} \text { and } \\
\mathrm{Zr} / \mathrm{Rb} \text { upwards. } \mathrm{Br} / \mathrm{Ti} \text { and } \mathrm{S} / \mathrm{Ti} \\
\text { decrease upwards at base of } \mathrm{Tu} \text {, } \\
\text { peak in } \mathrm{S} / \mathrm{Ti} \text { near the top of } \mathrm{Tu} \text {. }\end{array}$ & $\begin{array}{l}\text { Smooth Tu base, well-sorted in } \\
\text { the basal interval below fainter } \\
\text { Tu layering. Big grains near the } \\
\text { top of the } \mathrm{Hm} \text {. }\end{array}$ & $\begin{array}{l}\text { 'Classic' turbidite of unknown } \\
\text { origin. Grains near top probably } \\
\text { result from post-depositional } \\
\text { alteration. }\end{array}$ \\
\hline UC-5 (mar) & $\begin{array}{l}1 \text { (Tu+ } \\
\mathrm{Hm} 1+ \\
\mathrm{Hm} 2)\end{array}$ & 280 & $\begin{array}{l}\text { Fining upwards } \mathrm{Tu}, \\
\text { similar grainsize } \mathrm{Hm} \\
\text { and hemipelagic } \\
\text { deposits }\end{array}$ & $\begin{array}{l}\text { Higher Magnetic } \\
\text { Susceptibility, AMS } \\
\text { foliation and corrected } \\
\text { anisotropy degree } \mathrm{Pj} \text { in } \\
\mathrm{Hm} \text { 's, both slightly lower } \\
\text { in Hm2 than Hm1 }\end{array}$ & $\begin{array}{l}\text { Higher } \mathrm{Zr} / \mathrm{Rb} \text {, lower } \mathrm{Fe} / \mathrm{Si} \text { in } \mathrm{Tu}, \\
\text { lower } \mathrm{Ca} / \mathrm{Ti}, \mathrm{Ca} / \mathrm{Fe}, \mathrm{Br} / \mathrm{Ti} \text { and } \\
\mathrm{S} / \mathrm{Ti} \text { in } \mathrm{Hm} \text { 's, slightly more } \\
\text { variable in } \mathrm{Hm} 1 \text { than } \mathrm{Hm} 2\end{array}$ & $\begin{array}{l}\text { Non-horizontal, sharp turbidite } \\
\text { base. Clear layering in turbidite } \\
\text { and faint layering in } \mathrm{Hm} 1 . \\
\text { Bioturbated top of } \mathrm{Hm} 2 .\end{array}$ & $\begin{array}{l}\text { Complex TuHm sedimentary } \\
\text { event, possibly of seismic origin, } \\
\text { with two settling phases for } \mathrm{Hm} 1 \\
\text { and } \mathrm{Hm} 2\end{array}$ \\
\hline UC-6 (mar) & $\begin{array}{c}1 \\
(\mathrm{Tu}+ \\
\mathrm{Hm} 1+ \\
\mathrm{Hm} 2)\end{array}$ & 193 & $\begin{array}{l}\text { Fining upwards Tu, } \\
\text { similar grainsize } \mathrm{Hm} 2 \\
\text { and hemipelagic } \\
\text { deposits, slightly more } \\
\text { variable in } \mathrm{Hm} 1\end{array}$ & $\begin{array}{l}\text { Higher Magnetic } \\
\text { Susceptibility, AMS } \\
\text { foliation and corrected } \\
\text { anisotropy degree Pj in } \\
\text { Hm's, both slightly lower } \\
\text { in Hm2 than Hm1 }\end{array}$ & $\begin{array}{l}\text { Higher } \mathrm{Zr} / \mathrm{Rb} \text {, lower } \mathrm{Fe} / \mathrm{Si} \text { in } \mathrm{Tu} \text {, } \\
\text { lower } \mathrm{Ca} / \mathrm{Ti}, \mathrm{Ca} / \mathrm{Fe}, \mathrm{Br} / \mathrm{Ti} \text { and } \\
\mathrm{S} / \mathrm{Ti} \text { in } \mathrm{Hm} \text { 's, slightly higher in } \\
\mathrm{Hm} 2 \text { than } \mathrm{Hm} 1\end{array}$ & $\begin{array}{l}\text { Tu erosive base displays both } \\
\text { rounded zones and linear } \\
\text { features. Within several coarse } \\
\text { turbiditic pulses, complex } \\
\text { microprogradations and } \\
\text { microfractures. Sharp limit } \\
\text { between Tu and Hm1, and } \\
\text { between Hm1 and Hm2. }\end{array}$ & $\begin{array}{l}\text { Complex TuHm sedimentary } \\
\text { event of seismic origin. Evidence } \\
\text { of liquefaction and microfractures } \\
\text { at Tu base, to-and fro- } \\
\text { displacements and coeval } \\
\text { shaking within Tu, and two } \\
\text { settling phases for } \mathrm{Hm} 1 \text { and Hm2 }\end{array}$ \\
\hline UC-7 (ISI) & $\begin{array}{c}1(\mathrm{Tu}+ \\
\mathrm{Hm})\end{array}$ & 70 & $\begin{array}{l}\text { Few data, but larger } \\
\text { grainsize at base of Tu }\end{array}$ & $\begin{array}{l}\text { Peak in Magnetic } \\
\text { Susceptibility at top of }\end{array}$ & $\begin{array}{l}\text { Higher } \mathrm{Zr} / \mathrm{Rb} \text { and } \mathrm{Ca} / \mathrm{Fe}+\text { lower } \\
\mathrm{Fe} / \mathrm{Si} \text { and } \mathrm{Ca} / \mathrm{Ti} \text { in } \mathrm{Tu} \text {, Upwards }\end{array}$ & $\begin{array}{l}\text { Sharp Tu base and transition to } \\
\mathrm{Hm} \text {. Top of } \mathrm{Hm} \text { contains big }\end{array}$ & $\begin{array}{l}\text { Tu/Hm sedimentary event, } \\
\text { possibly of seismic origin. Grains }\end{array}$ \\
\hline
\end{tabular}




\begin{tabular}{|c|c|c|c|c|c|c|c|}
\hline & & & $\begin{array}{l}\text { and smaller grainsize } \\
\text { Hm's and hemipelagic } \\
\text { deposits }\end{array}$ & $\mathrm{Hm}$ & $\begin{array}{l}\text { increasing } \mathrm{Fe} / \mathrm{Si} \text { and upwards } \\
\text { decreasing } \mathrm{Ca} / \mathrm{Fe} \text { in } \mathrm{Hm} \text {. }\end{array}$ & $\begin{array}{l}\text { grains around transition to } \\
\text { hemipelagic sediments. }\end{array}$ & $\begin{array}{l}\text { near top probably result from } \\
\text { post-depositional alteration. }\end{array}$ \\
\hline & $\begin{array}{l}2 \text { (Tu+ } \\
\mathrm{Hm} 1+ \\
\mathrm{Hm} 2)\end{array}$ & 160 & $\begin{array}{l}\text { Few data, but larger } \\
\text { grainsize at base of Tu } \\
\text { and smaller grainsize } \\
\text { Hm's and hemipelagic } \\
\text { deposits }\end{array}$ & $\begin{array}{l}\text { Peak in Magnetic } \\
\text { Susceptibility at the Hm1 } \\
\text { to } \mathrm{Hm} 2 \text { transition }\end{array}$ & $\begin{array}{l}\text { Higher } \mathrm{Zr} / \mathrm{Rb}, \mathrm{Ca} / \mathrm{Fe}, \mathrm{Ca} / \mathrm{Ti} \mathrm{S} / \mathrm{Ti} \\
\text { and } \mathrm{Br} / \mathrm{Ti}+\text { lower } \mathrm{Fe} / \mathrm{Si} \text { in } \mathrm{Tu} \text {. } \\
\text { Relatively low } \mathrm{Ca} / \mathrm{Fe} \text { and } \mathrm{Ca} / \mathrm{Ti} \text { in } \\
\text { Hm's, lower in } \mathrm{Hm} 2 \text { than } \mathrm{Hm} 1 \text {. }\end{array}$ & $\begin{array}{l}\text { Sharp Tu base and transitions } \\
\text { Tu-Hm1 and } \mathrm{Hm} 1-\mathrm{Hm} 2 \text {. Clear } \\
\text { layering in Tu, faint layering in } \\
\mathrm{Hm} 1 \text { and. } \\
\text { Big grains around } \mathrm{Hm} 1-\mathrm{Hm} 2 \\
\text { sediments. Bioturbated top of } \\
\mathrm{Hm} 2 \text {. }\end{array}$ & $\begin{array}{l}\text { Tu/Hm sedimentary event, } \\
\text { possibly of seismic origin, with } \\
\text { two settling phases for } \mathrm{Hm} 1 \text { and } \\
\text { Hm2. Grains near Hm1-Hm2 } \\
\text { transition probably result from } \\
\text { post-depositional alteration. }\end{array}$ \\
\hline UC-8 (ISI) & $\begin{array}{l}1(\mathrm{Tu}+ \\
\mathrm{Hm} 1+ \\
\mathrm{Hm} 2+ \\
\mathrm{Hm} 3)\end{array}$ & 280 & $\begin{array}{l}\text { Few data, but } \\
\text { generally fining } \\
\text { upwards within Tu/Hm } \\
\text { sedimentary event }\end{array}$ & $\begin{array}{l}\text { Peak in Magnetic } \\
\text { Susceptibility near top of } \\
\text { Hm2. Relatively high } \\
\text { AMS foliation and } \\
\text { corrected anisotropy } \\
\text { degree Pj in Tu and } \\
\text { Hm3 }\end{array}$ & $\begin{array}{l}\text { Relatively high } \mathrm{Zr} / \mathrm{Rb} \text { and low } \\
\mathrm{Fe} / \mathrm{Si} \text { in } \mathrm{Tu} \text {. Sharp increases in } \\
\mathrm{Fe} / \mathrm{Si} \text { and decreases in } \mathrm{Ca} / \mathrm{Fe} \\
\text { upwards for } \mathrm{Hm} 1-\mathrm{Hm} 2 \text { and } \mathrm{Hm} 2- \\
\mathrm{Hm} 3 \text { transitions. Overall lower } \\
\mathrm{S} / \mathrm{Ti} \text { and } \mathrm{Br} / \mathrm{Ti} \text { within } \mathrm{Tu} / \mathrm{Hm} \\
\text { compared to hemipelagic } \\
\text { sediments. }\end{array}$ & $\begin{array}{l}\text { Smooth turbidite base and faint } \\
\text { layering within turbidite. Sharp } \\
\text { base of } \mathrm{Hm} 1 \text { and more subtle } \\
\text { transitions between } \mathrm{Hm} 1-\mathrm{Hm} 2 \\
\text { and } \mathrm{Hm} 2-\mathrm{Hm} 3 \text {. Big grains around } \\
\mathrm{Hm} 2-\mathrm{Hm} 3 \text { transition. Sharp top of } \\
\mathrm{Hm} 3 \text { and clear contrast with } \\
\text { layered hemipelagic sediments. }\end{array}$ & $\begin{array}{l}\text { Tu/Hm sedimentary event, } \\
\text { possibly of seismic origin, with } \\
\text { three settling phases for } \mathrm{Hm} 1 \text {, } \\
\mathrm{Hm} 2 \text { and } \mathrm{Hm} 3 \text {. Grains near } \\
\mathrm{Hm} 2-\mathrm{Hm} 3 \text { transition probably } \\
\text { result from post-depositional } \\
\text { alteration. }\end{array}$ \\
\hline
\end{tabular}

